Asymmetric Syntheses of 3-Deoxy-3-aminosphingoid Bases:

\title{
Approaches Based on Parallel Kinetic Resolution and Double Asymmetric Induction
}

Kristína Csatayová, ${ }^{\dagger}$ Stephen G. Davies,* Ai M. Fletcher, Thomas R. Fowler,

Matthew S. Kennedy, Paul M. Roberts, and James E. Thomson

Department of Chemistry, Chemistry Research Laboratory,

University of Oxford, Mansfield Road, Oxford OX1 3TA, U.K.

steve.davies@chem.ox.ac.uk

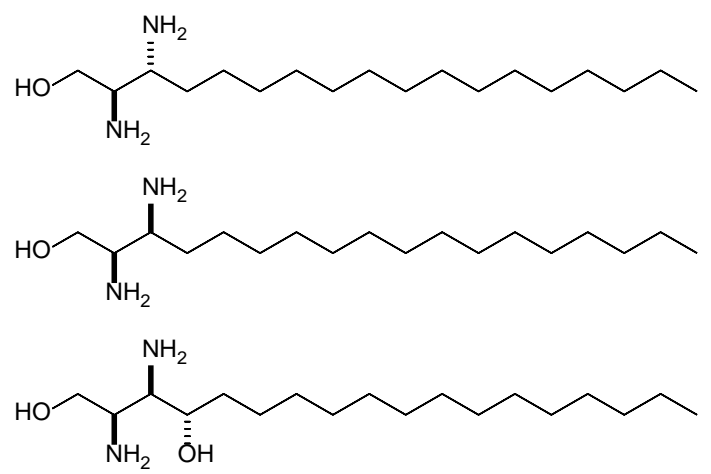

The asymmetric syntheses of a range of $\mathrm{N}$ - and $\mathrm{O}$-protected 3-deoxy-3-aminosphingoid bases have been achieved using two complementary approaches. DL-Serine was converted to a racemic $N, N$-dibenzylprotected $\gamma$-amino- $\alpha, \beta$-unsaturated ester which was resolved using a parallel kinetic resolution (PKR) strategy upon reaction with a pseudoenantiomeric mixture of lithium (R)- $N$-benzyl- $N$ - $(\alpha-$ methylbenzyl)amide and lithium (S)-N-3,4-dimethoxybenzyl- $N$-( $\alpha$-methylbenzyl)amide, giving the corresponding enantio- and diastereoisomerically pure $\beta, \gamma$-diamino esters. Alternatively, elaboration of Lserine gave the corresponding enantiopure $N, N$-dibenzyl-protected $\gamma$-amino- $\alpha, \beta$-unsaturated ester, and doubly diastereoselective conjugate addition of the antipodes of lithium $N$-benzyl- $N$-( $\alpha$-methylbenzyl)amide was found to proceed under the dominant stereocontrol of the lithium amide reagent in both cases, thus augmenting the accessible range of $\beta, \gamma$-diamino esters. Both of these protocols were expanded to include in situ oxidation of the enolate formed upon conjugate addition, giving access to the corresponding $\alpha$-hydroxy$\beta, \gamma$-diamino esters. Elaboration of these $\beta, \gamma$-diamino and $\alpha$-hydroxy- $\beta, \gamma$-diamino esters gave the protected forms of the 3-deoxy-3-aminosphingoid base targets. 


\section{Introduction}

The sphingoid bases, of which sphinganine 1, sphingosine 2 and phytosphingosine 3 (Figure 1) are the archetypal members of the various sub-classes, form the backbone of sphingolipids, which are essential components of all eukaryotic cells. The sphingoid bases and their derivatives (ceramides, sphingolipids) play varied and important roles in cell structure, cell signalling, and even cell death. As such, there has been much interest in their synthesis ${ }^{1}$ and in the synthesis of analogues ${ }^{2}$ (Figure 1).
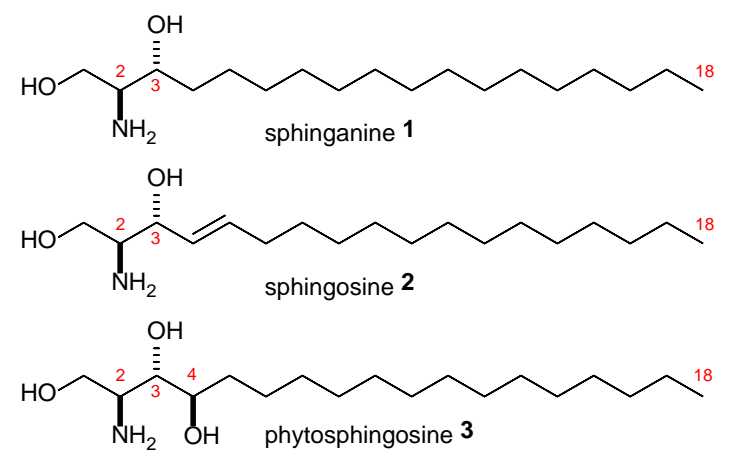

FIGURE 1. Structures of the archetypal sphingoid bases: sphinganine 1, sphingosine 2 and phytosphingosine 3.

We have previously investigated the parallel kinetic resolution (PKR) of a range of racemic $N, N$ dibenzyl-protected $\gamma$-amino- $\alpha, \beta$-unsaturated esters $(R S)$-4-8 (derived from the corresponding racemic $\alpha$ amino acids) using the conjugate addition of a 50:50 pseudoenantiomeric mixture of lithium (R)- $N$-benzyl$N$-( $\alpha$-methylbenzyl)amide 10 and lithium (S)- $N$-3,4-dimethoxybenzyl- $N$-( $\alpha$-methylbenzyl)amide $11 .^{3}$ The key features of the PKR protocol are as follows: (i) the chiral $\alpha, \beta$-unsaturated esters (RS)-4-8 exhibit a preference for the formation of the corresponding 3,4-syn products 12-16 upon conjugate addition of achiral lithium $N$-benzyl- $N$-isopropylamide 9 and (ii) this substrate control, when combined with the known diastereoselectivity elicited by lithium amides $(R)-\mathbf{1 0}$ and $(S)-\mathbf{1 1}$ (reagent control) ${ }^{4}$ leads to high levels of enantiorecognition and hence efficient PKR. For example, PKR of the $\alpha, \beta$-unsaturated ester (RS)-8, derived from DL-serine, gave a 50:50 mixture of the corresponding enantiopure $\beta, \gamma$-diamino esters 26 and 31, and chromatographic separation gave 26 in 37\% yield and 31 in 40\% yield, as single diastereoisomers in both cases $^{3}$ (Scheme 1). 


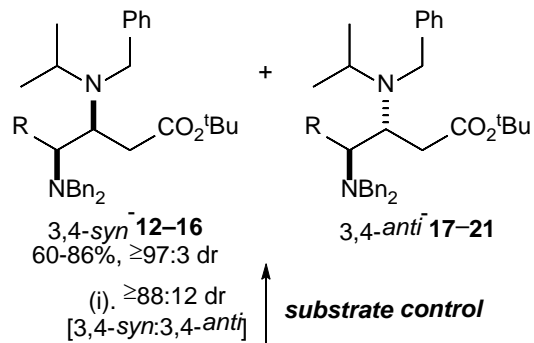<smiles>[R]CC([R16])/C=C/C(=O)OCc1ccccc1</smiles>

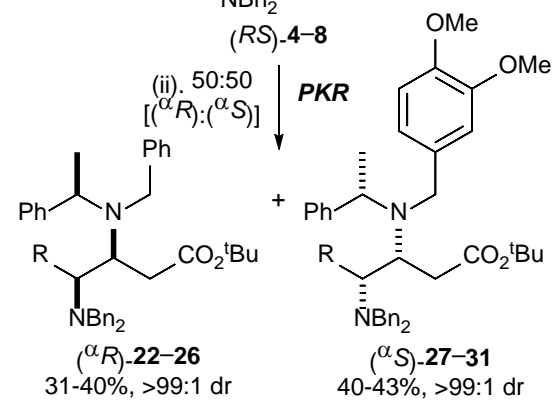

\begin{tabular}{|c|c|c|c|c|}
\hline substrate & \multicolumn{2}{|c|}{ (i). substate control } & \multicolumn{2}{|c|}{ (ii). PKR } \\
\hline $\mathbf{R}$ & 3,4-syn:3,4-ant & 3,4 -syn yield & $\left({ }^{\alpha} R\right)$ yield & $\left({ }^{\alpha} S\right)$ yield \\
\hline $\mathrm{Me}$ & $>99: 1[\mathbf{1 2}: \mathbf{1 7}]$ & $12,86 \%$ & $22,40 \%$ & $27,43 \%$ \\
\hline Et & 94: $6[13: 18]$ & $13,67 \%$ & 23, 31\% & $28,40 \%$ \\
\hline $\mathrm{Bn}$ & 97: 3 [14:19] & $14,78 \%{ }^{b}$ & $24,42 \%$ & $29,43 \%$ \\
\hline iBu & 98: 2 [15:20] & $15,72 \%^{c}$ & $25,39 \%$ & $30,43 \%$ \\
\hline $\mathrm{CH}_{2} \mathrm{OBn}$ & $88: 12[16: 21]$ & $16,60 \%$ & $26,37 \%$ & $31,40 \%$ \\
\hline
\end{tabular}

${ }^{a}$ Reagents and conditions: (i) lithium $N$-benzyl- $N$-isopropylamide 9, THF, $-78{ }^{\circ} \mathrm{C}, 2 \mathrm{~h}$; (ii) lithium $(R)$ - $N$-benzyl- $N$ - $(\alpha-$ methylbenzyl)amide 10, lithium (S)- $N$-3,4-dimethoxybenzyl- $N$-( $\alpha$-methylbenzyl)amide 11, THF, $-78{ }^{\circ} \mathrm{C}, 2$ h. ${ }^{b} 97: 3 \mathrm{dr}[\mathbf{1 4}: 19]$. c98:2 dr [15:20].

We proposed that this PKR protocol could be utilised as the key step in the synthesis of a range of 3deoxy-3-aminosphingoid bases via elaboration of a suitable enantiopure $\beta$, $\gamma$-diamino ester $33(X=H)$, derived from DL-serine. Alternatively, enantiopure $33(\mathrm{X}=\mathrm{H})$ could also be accessed via an approach based upon double asymmetric induction, ${ }^{5}$ involving the conjugate addition of an enantiopure lithium amide to the corresponding enantiopure $N$ - and $O$-protected $\alpha, \beta$-unsaturated ester 32, derived from L-serine. Further, if an electrophilic oxygen source was used (rather than a proton) as a quenching agent for the intermediate enolate(s) formed upon conjugate addition to $N, N$-dibenzyl-protected $\gamma$-amino- $\alpha$ - $\beta$-unsaturated ester 32 in either of these approaches, then the complementary series of enantiopure $\alpha$-hydroxy- $\beta, \gamma$-diamino esters 33 $(\mathrm{X}=\mathrm{OH})$ would also be accessible. ${ }^{6-9}$ It was proposed that chemoselective $O$-deprotection of $33(\mathrm{X}=\mathrm{H}$, $\mathrm{OH})$ with in situ cyclisation would furnish the corresponding lactone $\mathbf{3 4}$. Reduction of $\mathbf{3 4}$ was anticipated to yield the corresponding lactol 35, and elaboration of 35 via Wittig olefination would give 36. Tandem hydrogenation/hydrogenolysis of $\mathbf{3 6}$ would then give the corresponding 3-deoxy-3-aminosphingoid base 37 (Figure 2). This approach avoids the stoichiometric formation of a potentially unstable $\beta$-amino aldehyde intermediate (the lactol 35 acting as a masked form of this species). We delineate herein the results of our investigations within this area. 


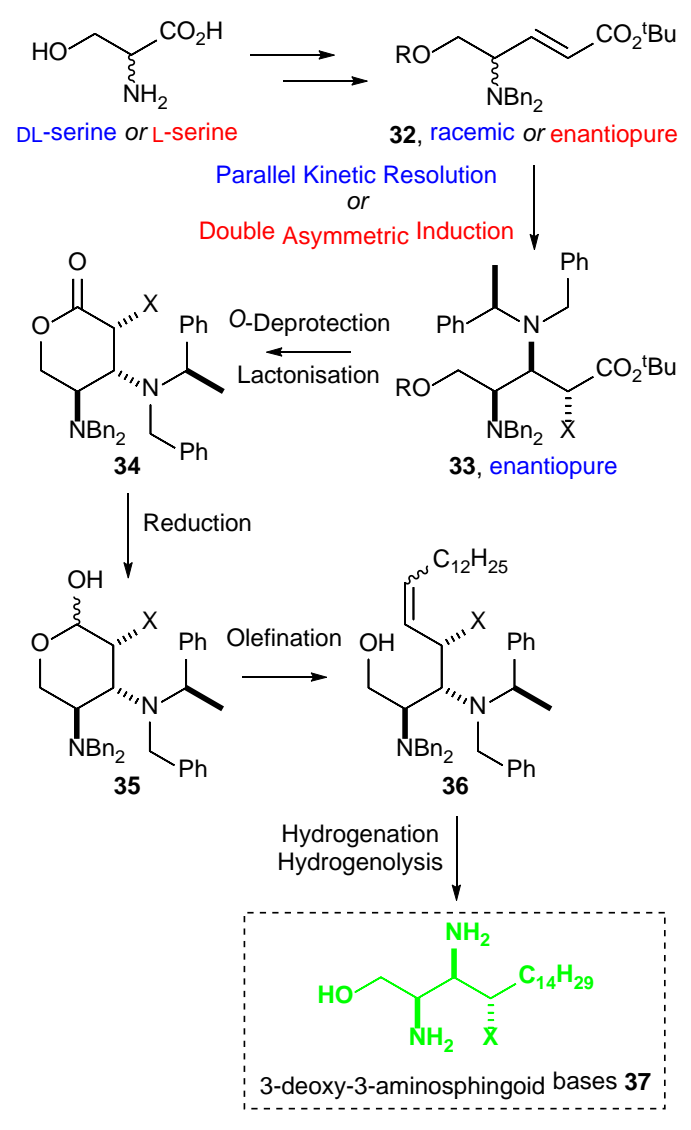

FIGURE 2. Enantiopure $\beta, \gamma$-diamino esters or $\alpha$-hydroxy- $\beta, \gamma$-diamino esters 33 ( $\mathrm{X}=\mathrm{H}$ or $\mathrm{OH}$ ), derived from (i) DL-serine using $\mathrm{PKR}$, or (ii) L-serine using double asymmetric induction, as precursors to 3-deoxy-3-aminosphingoid bases 37 ( $\mathrm{X}=\mathrm{H}$ or $\mathrm{OH}$ ).

\section{Results and Discussion}

Although we have already evaluated racemic $N, N, O$-tribenzyl-protected $\alpha, \beta$-unsaturated ester (RS)-8 in the PKR reaction manifold, ${ }^{3}$ this was synthesised from $O$-benzyl DL-serine which is a relatively high-cost starting material, meaning that its applicability for larger-scale synthesis is limited. In addition, the global $N$ and $O$-benzyl protection of the corresponding enantiopure $\beta, \gamma$-diamino esters $\mathbf{2 6}$ and $\mathbf{3 1}$ (Scheme 1 ) was not anticipated to be ideal for the proposed chemoselective $O$-debenzylation step in the synthesis. Therefore, it was resolved to pursue the synthesis of an orthogonally $N, O$-protected $\alpha, \beta$-unsaturated ester starting from DL-serine: this material is inexpensive, readily available in multigram quantities, and obviously allows the incorporation of orthogonal $N$ - and $O$-protecting groups. Based upon our previous approach to racemic $N, N$ dibenzyl-protected $\gamma$-amino- $\alpha, \beta$-unsaturated esters $(R S)-\mathbf{4}-\mathbf{8},{ }^{3}$ treatment of DL-serine with $\mathrm{BnBr}$ and $\mathrm{K}_{2} \mathrm{CO}_{3}$ gave $(R S)$-38 in 55\% yield. O-Silyl protection of $(R S)$-38 was then readily achieved by treatment with TIPSCl and imidazole, which proceeded to give (RS)-39 in 81\% isolated yield. Reduction of (RS)-39 by treatment with DIBAL-H gave alcohol (RS)-43 in 87\% yield. Swern oxidation of (RS)-43 to the corresponding aldehyde was followed by in situ Wittig olefination upon addition of $\mathrm{Ph}_{3} \mathrm{P}=\mathrm{CH}_{2} \mathrm{CO}_{2}{ }^{\mathrm{t}} \mathrm{Bu}$ to give racemic $\alpha, \beta$-unsaturated ester $(R S)-44 \mathrm{in}>99: 1 \mathrm{dr}\left[(E):(Z)\right.$ ratio]. ${ }^{1} \mathrm{H}$ NMR ${ }^{3} J$ coupling constant analysis showed a diagnostic value of ${ }^{3} \mathrm{~J}=15.8 \mathrm{~Hz}$ between $\mathrm{C}(2) H$ and $\mathrm{C}(3) H$ olefinic protons, enabling confident 
assignment of the expected (E)-geometry for the newly formed carbon-carbon double bond within (RS)-44. Purification gave (RS)-44 in 72\% yield, representing an overall yield of 28\% from DL-serine. Hulme et al. have reported a strategy for the preparation of an analogue of $\mathbf{4 3}$ bearing an $O$-TBDPS rather than $O$-TIPS group. ${ }^{10}$ Following this protocol, methyl ester hydrochloride salt $(R S)-\mathbf{4 0}$ was formed upon treatment of DLserine with $\mathrm{AcCl}$ in $\mathrm{MeOH}$, in 85\% yield. Treatment of (RS)-40 with $\mathrm{BnBr}$ and $\mathrm{K}_{2} \mathrm{CO}_{3}$ gave $(R S)-\mathbf{4 1}$ in $89 \%$ yield. O-Silyl protection of (RS)-41 by treatment with TIPSCl and imidazole proceeded to give (RS)-42 in 87\% yield. This procedure could be telescoped [i.e., omitting purification of intermediates $(R S)-\mathbf{4 0}$ and $(R S)$ 41], which allowed isolation of (RS)-42 in 82\% overall yield from DL-serine. Reduction of (RS)-42 with DIBAL-H gave alcohol (RS)-43 in 78\% isolated yield, which could be elaborated to (RS)-44 as before. However, when alcohol (RS)-43 was subjected (without prior purification) to the one pot Swern/Wittig reaction, racemic $\alpha, \beta$-unsaturated ester $(R S)$-44 was isolated in 79\% yield and >99:1 dr $[(E):(Z)$ ratio] over the two steps from $(R S)-42$. Thus, the route via methyl ester $(R S)-42$ was higher yielding than the route via benzyl ester $(R S)$-39, despite the involvement of an additional synthetic step in the former case: $(R S)-\mathbf{4 4}$ was prepared from DL-serine in 65\% overall yield in five steps (with two chromatographic purifications) via methyl ester $(R S)-42$, compared to only $28 \%$ overall yield in four steps (with four chromatographic purifications) via benzyl ester $(R S)$-39. The optimum route enabled routine synthesis of $>15 \mathrm{~g}$ batch quantities of (RS)-44. As enantiopure 44 was required to evaluate the effects of double asymmetric induction, a sample of $(R)-44$ was prepared via an analogous procedure but starting from L-serine. This synthesis could be run without purification of intermediates (S)-40, $(S)-\mathbf{4 1}$ and $(R)-\mathbf{4 3}$, giving $\alpha, \beta$ unsaturated ester $(R)-44$ in 76\% overall yield and $>99: 1 \mathrm{dr}[(E):(Z)$ ratio] in five steps (with two chromatographic purifications) from L-serine. Chiral HPLC analyses of (RS)-44 and (R)-44 allowed the enantiomeric purity of the sample of $(R)-\mathbf{4 4}$ to be determined as $99 \% \mathrm{ee}^{11}$ (Scheme 2).

\section{SCHEME $2^{a}$}

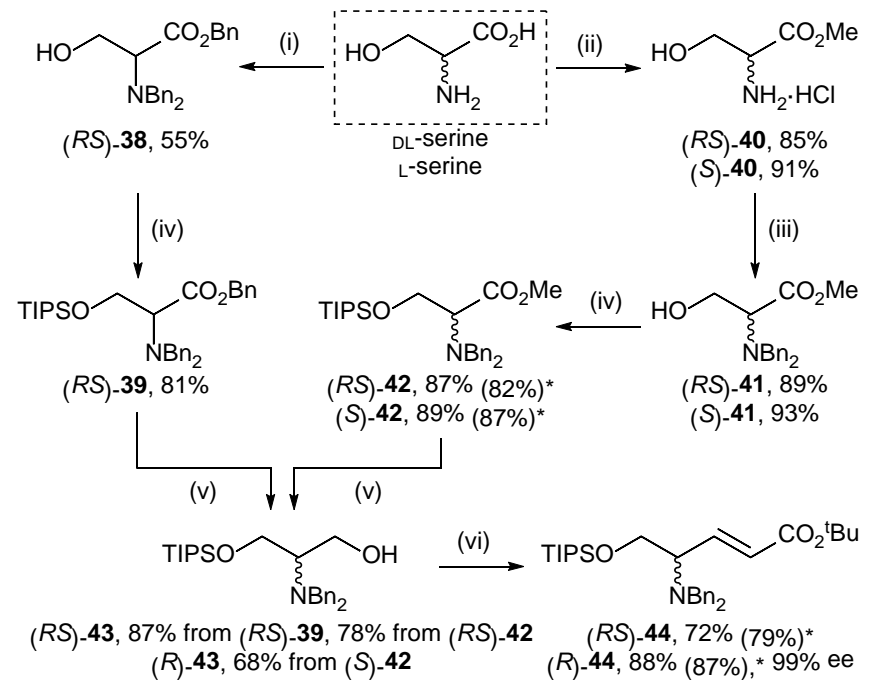

${ }^{a}$ Reagents and conditions: (i) $\mathrm{BnBr}, \mathrm{K}_{2} \mathrm{CO}_{3}, \mathrm{H}_{2} \mathrm{O}$, reflux, 18 h; (ii) $\mathrm{AcCl}, \mathrm{MeOH}$, reflux, 3 h; (iii) $\mathrm{BnBr}, \mathrm{K}_{2} \mathrm{CO}_{3}, \mathrm{MeCN}$, rt, 24 h; (iv) imidazole, TIPSCl, DMF, rt, 18 h; (v) DIBAL-H, PhMe, $-78{ }^{\circ} \mathrm{C}, 1 \mathrm{~h}$; (vi) $(\mathrm{COCl})_{2}, \mathrm{DMSO}, \mathrm{Et}_{3} \mathrm{~N} \mathrm{CH}_{2} \mathrm{Cl}_{2},-78{ }^{\circ} \mathrm{C}, 1 \mathrm{~h}$; $($ vii) 
$\mathrm{Ph}_{3} \mathrm{P}=\mathrm{CHCO}_{2}{ }^{\mathrm{t}} \mathrm{Bu}, \mathrm{CH}_{2} \mathrm{Cl}_{2}$, rt, 18 h. * Yields in parentheses are for telescoped processes (i.e., over three steps from serine for the synthesis of 42, and over two steps from 42 for the synthesis of $\mathbf{4 4}$, without purification of any intermediates).

Our standard procedure ${ }^{12}$ for evaluating the suitability of a racemic $\alpha, \beta$-unsaturated ester to undergo PKR using a pseudoenantiomeric mixture of lithium amides $\mathbf{1 0}$ and $\mathbf{1 1}$ involves first independently evaluating both the inherent levels of substrate control and the extent of recognition between the enantiomers of the substrate and reagent. The inherent substrate control is assessed upon conjugate addition of (achiral) lithium $N$-benzyl- $N$-isopropylamide 9 to the racemic $\alpha, \beta$-unsaturated ester, with high levels of substrate control being manifested in high diastereoselectivity upon conjugate addition. The extent of enantiorecognition is then quantified by conducting a mutual kinetic resolution (MKR), i.e., the addition of racemic lithium $N$-benzyl- $N$-( $\alpha$-methylbenzyl)amide $\mathbf{1 0}$ to the racemic $\alpha, \beta$-unsaturated ester. This approach eliminates the effect of mass action and readily allows quantification of the stereoselectivity factor, E, from the reaction diastereoselectivity, obtained by peak integration of the ${ }^{1} \mathrm{H}$ NMR spectrum of the crude reaction mixture. ${ }^{13}$ Systems for which $\mathrm{E} \geq 10$ can be expected to result in highly efficient PKR upon treatment with a 50:50 pseudoenantiomeric mixture of lithium amides $\mathbf{1 0}$ and 11. This approach was implemented for racemic $\alpha, \beta$-unsaturated ester $(R S)-\mathbf{4 4}$.

Addition of lithium amide 9 to racemic $\alpha, \beta$-unsaturated ester $(R S)-44$ in THF at $-78{ }^{\circ} \mathrm{C}$ gave a $96: 4$ mixture of the racemic, diastereoisomeric $\beta \gamma$-diamino esters 45 and 46, as established by ${ }^{1} \mathrm{H}$ NMR spectroscopic analysis of the crude reaction mixture. From this result, it is evident that $(R S)-\mathbf{4 4}$ shows very high levels of diastereocontrol upon conjugate addition of lithium amide $\mathbf{9}$. Following purification, $\mathbf{4 5}$ was isolated in 57\% yield as a single diastereoisomer, along with an impure sample of $\mathbf{4 6}$ in $<5 \%$ yield. The relative $(R S, S R)$ - and $(R S, R S)$-configurations of $\mathbf{4 5}$ and $\mathbf{4 6}$, respectively, were assigned by analogy to those of the corresponding $O$-benzyl-protected analogues 16 and 21, of known relative configuration: ${ }^{3}$ the ${ }^{1} \mathrm{H}$ NMR chemical shifts and ${ }^{3} J$ coupling constant values associated with the $\mathrm{C}(2) H_{2}$ protons of $\mathbf{1 6}$ and $\mathbf{4 5}$, and those of 21 and 46, displayed close parity. ${ }^{14}$ We have previously proposed a simplistic model to account for the diastereocontrol elicited by chiral $\alpha, \beta$-unsaturated esters 4-8 upon conjugate addition of lithium amide 9. ${ }^{3}$ This model is similar to the Felkin-Ahn model, whereby the configuration of the allylic stereocentre controls the stereochemical outcome of the reaction, with the lithium amide $\mathbf{9}$ approaching the double bond from the least hindered face. Based upon the observed solid-state conformation of (RS)-4 (derived from DLalanine), a reactive conformation was proposed whereby the $\mathrm{C}(4)$-hydrogen atom is at $90^{\circ}$ to the plane defined by the double bond, and the bulky C(4)- $N, N$-dibenzylamino group is in the less crowded "outside" position. ${ }^{3}$ In the case of $\mathbf{4 4}$, this corresponds to conformation 44A: approach of lithium amide 9 would then be predicted to occur over the hydrogen atom, leading to the 3,4-syn diastereoisomer $\mathbf{4 5}$ as the major product (Scheme 3). 


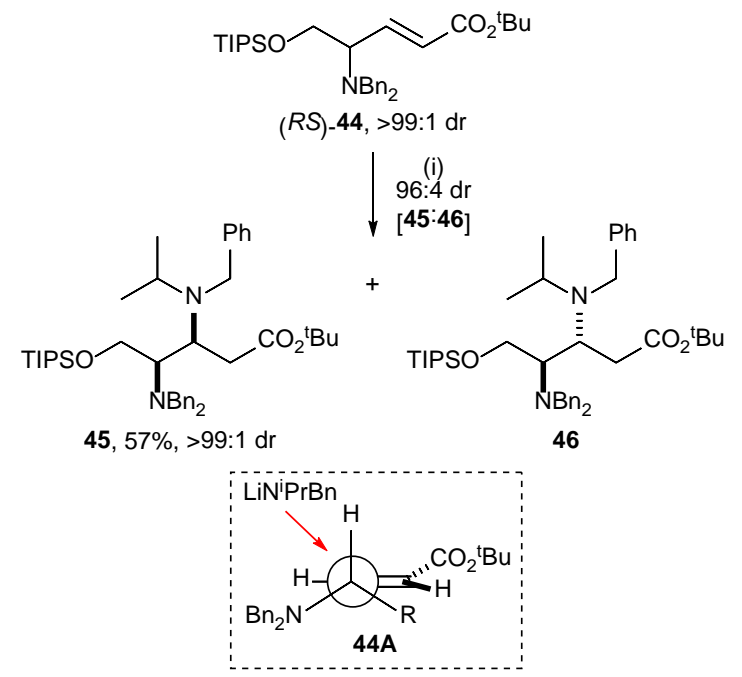

${ }^{a}$ Reagents and conditions: (i) lithium $N$-benzyl- $N$-isopropylamide 9 , THF, $-78^{\circ} \mathrm{C}, 2 \mathrm{~h}$. $\mathrm{R}=\mathrm{CH}_{2} \mathrm{OTIPS}$.

MKR of racemic lithium amide (RS)-10 and racemic $\alpha, \beta$-unsaturated ester (RS)-44 was next attempted. In the event, addition of (RS)-10 to $(R S)-\mathbf{4 4}$ gave a racemic $\beta \gamma$-diamino ester $\mathbf{4 7}$ as a single diastereoisomer, indicating a very high level of enantiorecognition $(\mathrm{E}>99),{ }^{13}$ with chromatographic purification giving 47 in $80 \%$ yield. The relative (3RS,4SR, $\alpha S R)$-configuration of 47 was initially assigned by analogy to the outcomes of MKR of the racemic $N, N$-dibenzyl-protected $\gamma$-amino- $\alpha, \beta$-unsaturated esters $(R S)$-4-8 with lithium amide $(R S)-10$, and later unambiguously confirmed by single crystal X-ray diffraction analysis of a derivative. The very high level of enantiorecognition observed in this MKR is consistent with the high level and sense of diastereocontrol shown by the substrate (RS)-44 upon conjugate addition of achiral lithium amide $\mathbf{9}$, as well as with the known diastereoselectivity elicited by chiral lithium amide $\mathbf{1 0}$ in its conjugate addition reactions to a range (>250 examples) of achiral $\alpha, \beta$-unsaturated esters ${ }^{4}$ (Scheme 4).

\section{SCHEME $4^{a}$}

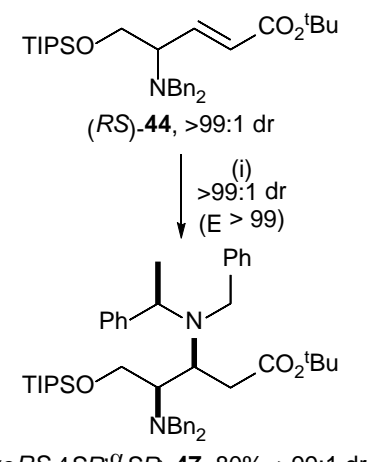

$\left(3 R S, 4 S R^{\prime \alpha}\right.$ SR)-47, 80\%, >99:1 dr

${ }^{a}$ Reagents and conditions: (i) lithium (RS)-N-benzyl- $N$-( $\alpha$-methylbenzyl)amide (RS)-10, THF, $-78{ }^{\circ} \mathrm{C}, 2 \mathrm{~h}$.

Following the successful MKR, reaction of an equimolar mixture of lithium amides $(R)-\mathbf{1 0}$ and $(S)$ 11 with racemic $\alpha, \beta$-unsaturated ester (RS)-44 gave a 50:50 mixture of only two enantiopure $\beta, \gamma$-diamino esters, 47 and 48, demonstrating efficient PKR. The difference in polarity between the phenyl group within 47 and the 3,4-dimethoxyphenyl group within 48 afforded good chromatographic separation, and 47 was isolated in $43 \%$ yield, whilst 48 was isolated in $35 \%$ yield. As expected, the ${ }^{1} \mathrm{H}$ and ${ }^{13} \mathrm{C}$ NMR spectra of this 
enantiopure sample of $\mathbf{4 7}$ proved to be identical to those for the racemic sample of $\mathbf{4 7}$ produced in the MKR of $(R S)$-44 using lithium amide (RS)-10. Thus, the absolute $(3 S, 4 R, \alpha R)$-configuration of the enantiopure sample of $\mathbf{4 7}$ was confidently assigned from the known $(R)$-configuration of the $\alpha$-methylbenzyl stereogenic centre derived from the lithium amide reagent $(R)-\mathbf{1 0}$. The absolute $(3 R, 4 S, \alpha S)$-configuration was therefore assigned to $\mathbf{4 8}$ on the basis that it is pseudoenantiomeric to $(3 S, 4 R, \alpha R)-\mathbf{4 7}$ (Scheme 5).

SCHEME $5^{a}$

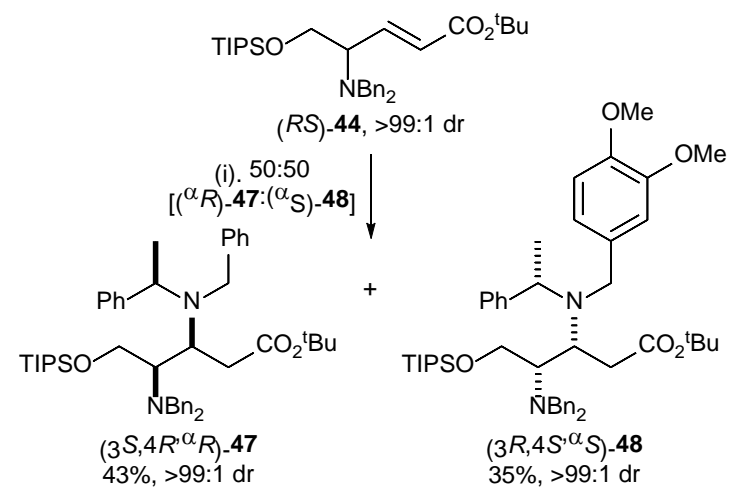

${ }^{a}$ Reagents and conditions: (i) lithium (R)- $N$-benzyl- $N$ - $(\alpha$-methylbenzyl)amide $(R)-\mathbf{1 0}$, lithium $(S)-N$-benzyl- $N$ - $(\alpha$-methyl-3,4dimethoxybenzyl)amide (S)-11, THF, $-78^{\circ} \mathrm{C}, 2 \mathrm{~h}$.

Attention now turned to evaluating double asymmetric induction, ${ }^{5}$ utilising the conjugate addition of the antipodes of lithium amide 10 to enantiopure $\alpha, \beta$-unsaturated ester $(R)-\mathbf{4 4}$, as an alternative method to access enantiopure $\beta, \gamma$-diamino esters, including 47. The sense of substrate control elicited by (RS)-44 upon conjugate addition of lithium amide $\mathbf{9}$ suggested that reaction of enantiopure lithium amide $(R)$-10 with enantiopure $\alpha, \beta$-unsaturated ester $(R)-44$ would constitute the "matched" pairing ${ }^{5}$ and give enantiopure $\beta, \gamma$ diamino ester $(3 S, 4 R, \alpha R)-47$ with high diastereoselectivity. In the event, addition of 1.6 equiv of lithium amide $(R)$-10 to $(R)$-44 gave 93\% conversion to $\mathbf{4 7}$ as a single diastereoisomer. When 2.0 equiv of lithium amide $(R)$-10 were used, quantitative conversion was achieved and $\mathbf{4 7}$ was isolated in $96 \%$ yield as a single diastereoisomer after chromatography. As expected, the ${ }^{1} \mathrm{H}$ and ${ }^{13} \mathrm{C}$ NMR spectroscopic data for this enantiopure sample of $\mathbf{4 7}$ were identical to those of the racemic sample isolated from the MKR reaction, and the enantiopure sample isolated from the PKR reaction; the signs and magnitudes of the specific rotations of both of the enantiopure samples of $\mathbf{4 7}$ (obtained by PKR and by double asymmetric induction) were identical (Scheme 6). 


\section{SCHEME $6^{a}$}

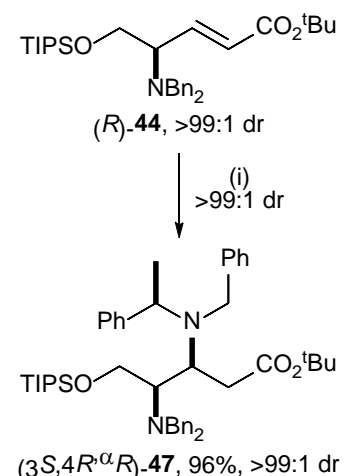

${ }^{a}$ Reagents and conditions: (i) lithium (R)- $N$-benzyl- $N$-( $\alpha$-methylbenzyl)amide $(R)-10$, THF, $-78^{\circ} \mathrm{C}, 2 \mathrm{~h}$.

The reaction of enantiopure lithium amide $(S)-\mathbf{1 0}$ with enantiopure $\alpha, \beta$-unsaturated ester $(R)-\mathbf{4 4}$ was expected to be the "mismatched" pairing, ${ }^{5}$ and hence expected to proceed with lower levels of diastereoselectivity, and at a slower rate, than the corresponding reaction of the "matched" pairing. ${ }^{5}$ Given the enantiopurities of both (S)-10 (i.e., >99\% ee) and (R)-44 (i.e., 99\% ee), it was anticipated that the "mismatched" reaction would form a maximum of two possible conjugate addition products: the C(3)epimers 49 and 50 (both in enantiopure form). Prior to conducting the experiment, however, it was not possible to predict the identity of the major diastereoisomer, as this would be governed by the dominant stereocontrolling factor: either the diastereocontrol of the lithium amide reagent $(S)$-10 (which was predicted to favour 49), or the diastereocontrol of the $\alpha, \beta$-unsaturated ester substrate $(R)-\mathbf{4 4}$ (which was predicted to favour 50). In the event, addition of 1.6 equiv of lithium amide $(S)-\mathbf{1 0}$ to $(R)-\mathbf{4 4}$ resulted $85 \%$ conversion to an 87:13 mixture of $\mathbf{4 9}$ and 50, respectively. When 2.0 equiv of lithium amide (S)-10 were used, quantitative conversion was achieved and an 87:13 mixture of $\mathbf{4 9}$ and $\mathbf{5 0}$ was isolated in 83\% combined yield after chromatography (Scheme 7). The absolute configuration of the newly formed C(3)-stereogenic centre of $\mathbf{4 9}$ was subsequently established unambiguously following single crystal X-ray diffraction analysis of a derivative, and thence $\mathbf{5 0}$ was assigned as the C(3)-epimer of 49. The reduced level (and opposite sense) of diastereoselectivity, coupled with the reduced conversion, displayed in the conjugate addition 1.6 equiv of lithium amide $(S)-\mathbf{1 0}$ to $(R)-\mathbf{4 4}(85 \%$ conversion, 87:13 dr) as compared to the conjugate addition of 1.6 equiv of lithium amide $(R)-\mathbf{1 0}$ to $(R)-\mathbf{4 4}$ (93\% conversion, >99:1 dr) validated the prediction that the former pairing is "mismatched" (and the latter "matched"). ${ }^{5}$ The production of $\mathbf{4 9}$ as the major diastereoisomeric product of this reaction shows that the dominant stereocontrolling element is the lithium amide reagent $(S)$ $\mathbf{1 0}$ and, therefore, the deployment of this double asymmetric induction strategy allows the diastereodivergent preparation of either the 3,4-syn- or 3,4-anti-configured $\beta, \gamma$-diamino esters $\mathbf{4 7}$ or $\mathbf{4 9}$, respectively. 


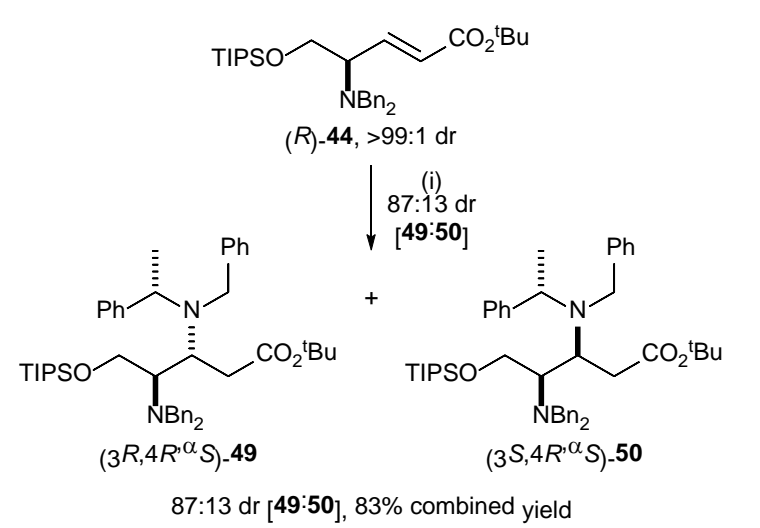

${ }^{a}$ Reagents and conditions: (i) lithium (S)- $N$-benzyl- $N$-( $\alpha$-methylbenzyl)amide (S)-10, THF, $-78^{\circ} \mathrm{C}, 2 \mathrm{~h}$.

With confirmation that the combination of enantiopure lithium amide $(R)-\mathbf{1 0}$ with enantiopure $\alpha, \beta$ unsaturated ester $(R)-\mathbf{4 4}$ constitutes the "matched" pairing, ${ }^{5}$ incorporation of an in situ enolate oxidation using camphorsulfonyloxaziridine (CSO $)^{6-9}$ was next investigated. First, the addition of lithium amide $(R)$ 10 to $(R)-44$ was carried out at an overall concentration of 0.08 M w.r.t. 44, and was followed by addition of (-)-CSO. This produced a complex mixture of products, containing enantiopure $\beta, \gamma$-diamino ester $\mathbf{4 7}$ and enantiopure $\beta, \gamma$-diamino 51 in an approximately 50:50 ratio, as determined by ${ }^{1} \mathrm{H}$ NMR spectroscopic analysis. However, the complexity of the crude reaction mixture precluded assessment of the diastereoisomeric purity of both 47 and 51. Purification by column chromatography gave 47 in $37 \%$ yield and 51 in 40\% yield, as single diastereoisomers in both cases. Treatment of $\mathbf{5 1}$ with $\mathrm{LiAlH}_{4}$ resulted in concomitant reduction of the ester functionality and removal of the $O$-silyl protecting group to give the corresponding triol 52 in 88\% yield (Scheme 8). The relative configuration within 52 was established unambiguously by single crystal X-ray diffraction analysis (Figure 3$),{ }^{15}$ with the absolute $(2 R, 3 R, 4 R, \alpha R)$ configuration following from the known $(R)$-configuration of the $\alpha$-methylbenzyl stereogenic center; in addition the determination of a Flack $x$ parameter ${ }^{16,17}$ for the structure of $-0.1(3)$ was consistent with this assignment. This analysis also allowed the absolute $(2 R, 3 R, 4 R, \alpha R)$-configuration of $\mathbf{5 1}$ to be unambiguously assigned, as well as the absolute $(3 S, 4 R, \alpha R)$-configuration of $\mathbf{4 7}$ since both $\mathbf{4 7}$ and $\mathbf{5 1}$ arise from the same intermediate enolate. In an attempt to increase the proportion of $\alpha$-hydroxy- $\beta, \gamma$-diamino ester $\mathbf{5 1}$ over $\beta, \gamma$ diamino ester $\mathbf{4 7}$ in the crude reaction mixture, the concentration of the reaction was increased by reducing the total volume of solvent. This strategy proved successful: increasing the overall concentration gave product ratios with increased proportions of $\alpha$-hydroxy- $\beta$-amino ester 51. At an overall concentration of 1.25 $\mathrm{M}$ w.r.t. 44, the product ratio of $\mathbf{4 7 : 5 1}$ was determined to be 24:76 by ${ }^{1} \mathrm{H}$ NMR spectroscopic analysis. Purification gave $\beta, \gamma$-diamino ester 47 in 16\% yield and $\alpha$-hydroxy- $\beta, \gamma$-diamino ester $\mathbf{5 1}$ in $73 \%$ yield. The efficacy of (+)-CSO in effecting the enolate oxidation was also assessed under these optimised conditions: in this case, however, analysis of the ${ }^{1} \mathrm{H}$ NMR spectrum of the crude reaction mixture indicated the presence of 
47 only. This result suggests that there are significant levels of enantiorecognition between the intermediate enolate [derived from conjugate addition of lithium amide $(R)-\mathbf{1 0}$ to $\alpha, \beta$-unsaturated ester $(R)-\mathbf{4 4}$ ] and the enantiomers of $\mathrm{CSO}^{6,7,18}$ (Scheme 8).

\section{SCHEME $8^{a}$}

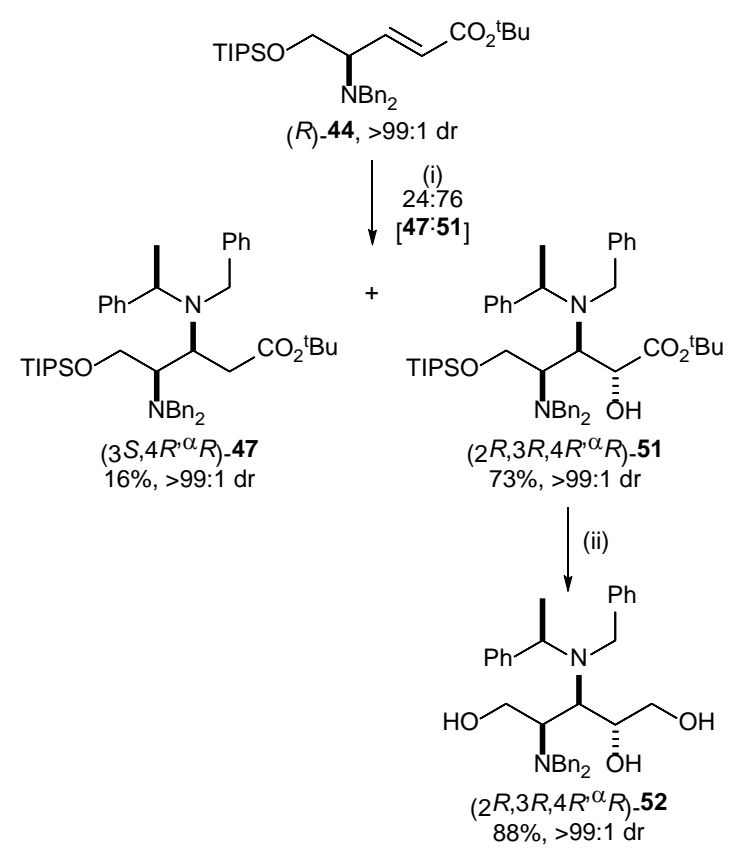

${ }^{a}$ Reagents and conditions: (i) lithium (R)-N-benzyl- $N$-( $\alpha$-methylbenzyl)amide $(R)-10$, THF, $-78{ }^{\circ} \mathrm{C}, 2 \mathrm{~h}$, then $(-)-\mathrm{CSO},-78^{\circ} \mathrm{C}$ to rt, 18 h; (ii) $\mathrm{LiAlH}_{4}$, THF, rt, 18 h.

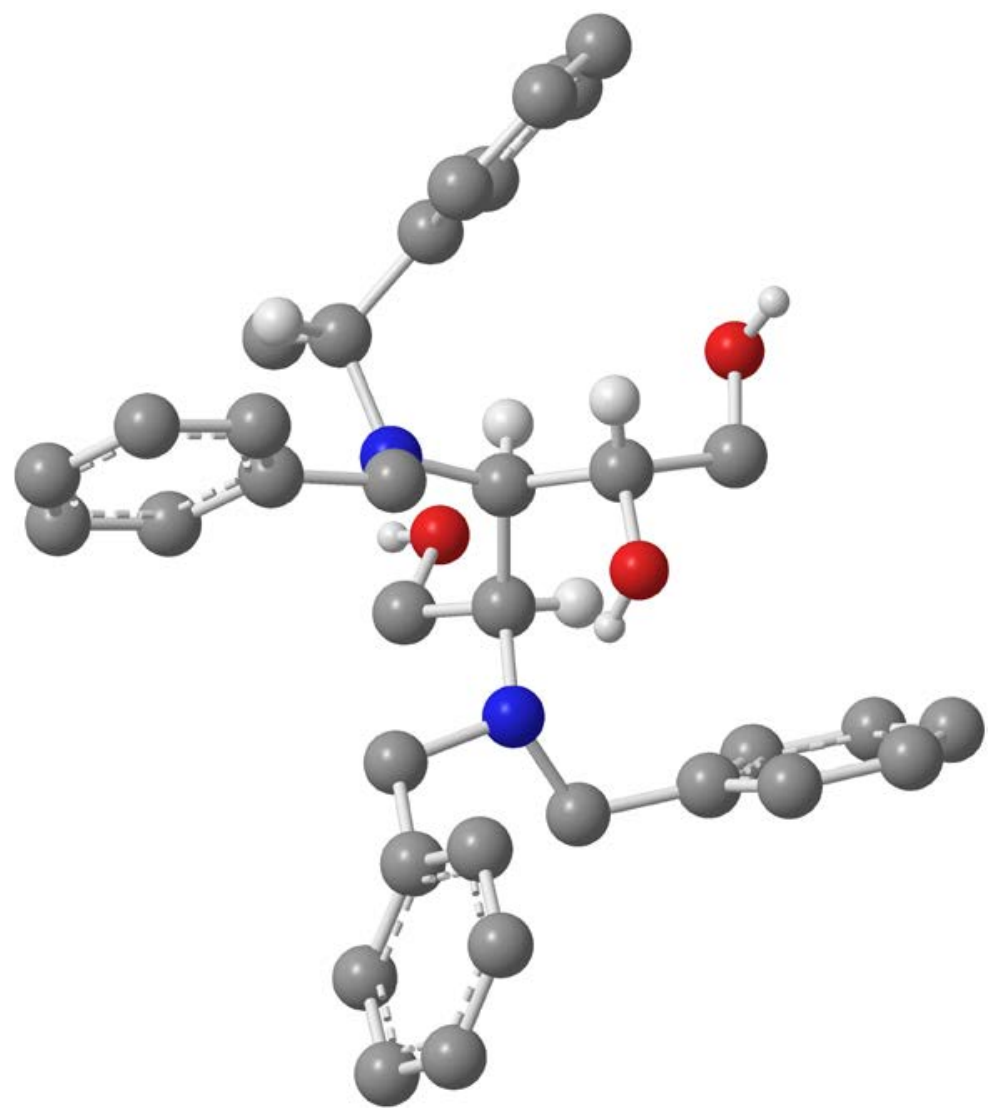

FIGURE 3. Chem3D representation of the X-ray crystal structure of $\mathbf{5 2}$ (selected H atoms are omitted for clarity).

The possibility of incorporating enolate oxidation into the PKR procedure was next briefly evaluated. As significant enantiorecognition was observed when quenching the intermediate enolate derived from 
conjugate addition of enantiopure lithium amide $(R)$-10 to enantiopure $\alpha, \beta$-unsaturated ester $(R)-\mathbf{4 4}$ with the antipodes of CSO, an equimolar mixture of (-)-CSO and (+)-CSO was used as the quenching agent for the PKR procedure: the intermediate enolates that must be present, viz. that derived from conjugate addition of lithium amide $(R)-\mathbf{1 0}$ to $(R)-\mathbf{4 4}$ and that derived from conjugate addition of lithium amide $(S)-\mathbf{1 1}$ to $(S)-\mathbf{4 4 ,}$ are pseudoenantiomeric and should thus show complementary reactivity with the enantiomers of CSO. Conjugate addition of lithium amides $(R)-\mathbf{1 0}$ and $(S)-\mathbf{1 1}$ to $(R S)-\mathbf{4 4}$ at an overall concentration of $1.25 \mathrm{M}$ w.r.t. 44 followed by addition of (-)-CSO and (+)-CSO gave a complex mixture of products. Substantial peak overlap in the ${ }^{1} \mathrm{H}$ NMR spectrum of the crude reaction mixture, coupled with the presence of CSO residues, enabled no information regarding product distribution or diastereoisomeric ratios to be gleaned. Chromatographic purification of this mixture allowed isolation of the enantiopure $\beta, \gamma$-diamino esters 47 and 48 (the result of enolate protonation) in $15 \%$ and $14 \%$ yields, respectively, along with enantiopure $\alpha$ hydroxy- $\beta, \gamma$-diamino esters 51 and 53 (the result of enolate oxidation) in 12\% and 4\% yields, respectively. The absolute $(2 S, 3 S, 4 S, \alpha S)$-configuration was assigned to $\mathbf{5 3}$ on the basis that it is pseudoenantiomeric to 51. Although the isolated yields of $\alpha$-hydroxy- $\beta, \gamma$-diamino esters $\mathbf{5 1}$ and $\mathbf{5 3}$ were rather low, these results suggest that the combination of PKR with enolate oxidation may prove useful in future scenarios (Scheme 9).

\section{SCHEME $9^{a}$}

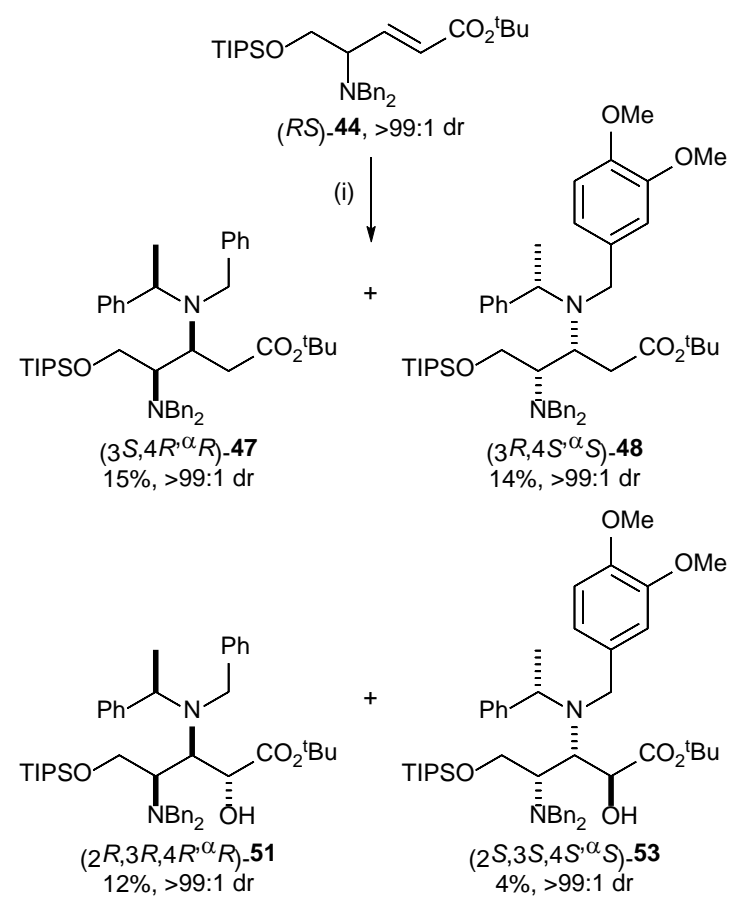

${ }^{a}$ Reagents and conditions: (i) lithium (R)- $N$-benzyl- $N$ - $(\alpha$-methylbenzyl)amide $(R)$-10, lithium $(S)-N$-benzyl- $N$ - $(\alpha$-methyl-3,4dimethoxybenzyl)amide (S)-11, THF, $-78{ }^{\circ} \mathrm{C}, 2 \mathrm{~h}$, then $(-)-\mathrm{CSO},(+)-\mathrm{CSO},-78{ }^{\circ} \mathrm{C}$ to rt, $18 \mathrm{~h}$.

With efficient routes to enantiopure $\beta, \gamma$-diamino esters 47 and $\mathbf{4 9}$, and enantiopure $\alpha$-hydroxy- $\beta, \gamma$ diamino ester 51 in place, their elaboration to the corresponding 3-deoxy-3-aminosphingoid bases was 
explored, with one of the key steps being $O$-desilylation followed by lactonisation. Treatment of enantiopure $\beta$-amino ester 47 with TBAF at $0{ }^{\circ} \mathrm{C}$ for 2 h gave $82 \%$ conversion to a $16: 84$ mixture of $\beta, \gamma$-diamino- $\delta$ hydroxy ester 54 and lactone 55, respectively. This was an encouraging result, as it showed that lactone 55 was forming in situ; presumably, following $O$-silyl deprotection, the basicity of the reaction mixture provides conditions which promote lactonisation of 54. Purification of the crude reaction mixture gave $\mathbf{4 7}$ in 9\% yield, 54 in 13\% yield and >99:1 dr, and 55 in 69\% yield and >99:1 dr. Optimisation of the reaction conditions led to complete $O$-desilylation and lactonisation as indicated by the presence of only 55 in ${ }^{1} \mathrm{H}$ NMR spectrum of the crude reaction mixture; in this case purification by chromatography gave $\mathbf{5 5}$ in $98 \%$ yield. ${ }^{1} \mathrm{H}$ NMR ${ }^{3} J$ coupling constant analysis of 55 was consistent with a half-chair conformation being adopted in solution, in which both of the bulky amino moieties adopt pseudoaxial positions, presumably to minimise 1,2-strain (Scheme 10).

\section{SCHEME 10}

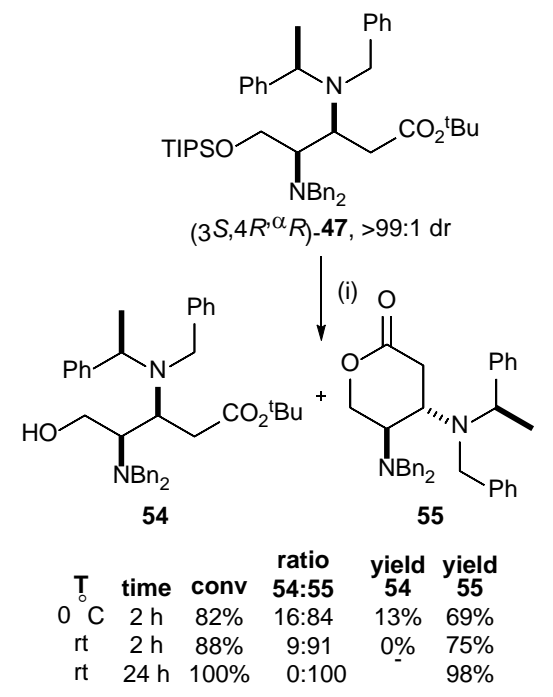

${ }^{a}$ Reagents and conditions: (i) TBAF, THF, temperature, time (see table).

A one-pot DIBAL-H reduction and Wittig olefination was next attempted on lactone 55. The choice of solvent proved critical for the success of this process: the optimum protocol involved treatment of $\mathbf{5 5}$ in PhMe (2 volumes) ${ }^{19}$ with DIBAL-H, followed by the addition of an excess (5 equiv) of the ylide derived from deprotonation of $\left[\mathrm{C}_{13} \mathrm{H}_{27} \mathrm{PPh}_{3}\right]^{+}[\mathrm{Br}]^{-}$in THF (1 volume) ${ }^{19}$ which produced an $~ 50: 50$ mixture of two compounds, 57 and 58, with chromatography giving an 50:50 mixture of 57 and $\mathbf{5 8}$ in $\mathbf{7 3 \%}$ combined yield. Peak overlap in the ${ }^{1} \mathrm{H}$ NMR spectrum of the purified mixture of 57 and 58 precluded ${ }^{3} J$ coupling constant analysis, although the ${ }^{13} \mathrm{C}$ NMR chemical shifts of the allylic carbon atoms [C(4) and C(7)] of both 57 and 58 were consistent with the presence of olefin isomers: the chemical shift values associated with these carbons of $\mathbf{5 7}$ were $\sim 5$ ppm higher than the corresponding resonances for $\mathbf{5 8}$, consistent with the so-called $\gamma$ effect $^{20}$ and hence signifying that $\mathbf{5 7}$ is the (E)-isomer and $\mathbf{5 8}$ is the (Z)-isomer. The importance of reaction solvent on the outcome of the two-step reduction/olefination reaction is underscored by the following 
observations: (1) Phosphonium salt $\left[\mathrm{C}_{13} \mathrm{H}_{27} \mathrm{PPh}_{3}\right]^{+}[\mathrm{Br}]^{-}$is insoluble in PhMe. (2) Attempted reduction of lactone 55 to lactol 56 using DIBAL-H in THF gave only 36\% conversion (to a 50:50 mixture of anomers) after $1 \mathrm{~h}$, which were isolated in 36\% combined yield after chromatography. Use of PhMe gave complete conversion to 56 (50:50 mixture of anomers) within the same time period, allowing isolation of lactols $\mathbf{5 6}$ in 85\% combined yield after chromatography. (3) Treatment of a solution of lactols 56 (50:50 mixture of anomers) in THF with BuLi, followed by the addition of a solution of the ylide derived from $\left[\mathrm{C}_{13} \mathrm{H}_{27} \mathrm{PPh}_{3}\right]^{+}[\mathrm{Br}]^{-}$in THF, returned only starting material 56, phosphonium salt and unidentified species; chromatographic purification gave only returned lactols 56 in 40\% yield (i.e., PhMe is required as a cosolvent to promote efficient olefination). With an efficient preparation of olefins $(E)-57$ and $(Z)-58$ developed, their elaboration to the target 3-deoxy-3-aminosphingoid base was investigated. Treatment of the mixture of (E)-57 and (Z)-58 with $\mathrm{H}_{2}(5 \mathrm{~atm})$ in the presence of Pearlman's catalyst $\left[\mathrm{Pd}(\mathrm{OH})_{2} / \mathrm{C}\right]$ in $1.25 \mathrm{M}$ methanolic $\mathrm{HCl}$ gave a white bulk that produced an intractable ${ }^{1} \mathrm{H}$ NMR spectrum. However, peracetylation of the crude reaction mixture and purification by recrystallization gave 3-deoxy-3-aminosphingoid base derivative 59 in 79\% yield [from the 50:50 mixture of (E)-57 and (Z)-58]. The convergence of the 50:50 mixture of (E)-57 and (Z)-58 into a single compound $\mathbf{5 9}$ in 79\% yield lends further support to their assignment as olefin isomers. The overall yield of $\mathbf{5 9}$ was $41 \%$ in ten steps from L-serine, or 16\% (out of a theoretical maximum of 50\%) in ten steps from DL-serine (Scheme 11).

\section{SCHEME $11^{\text {a }}$}

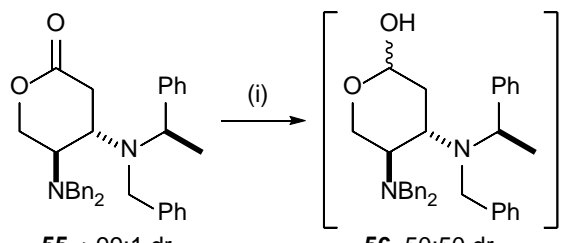

55, >99:1 dr

$56,50: 50 \mathrm{dr}$

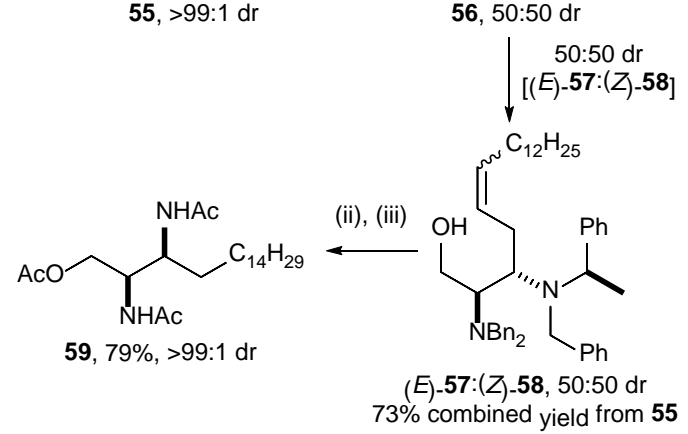

${ }^{a}$ Reagents and conditions: (i) DIBAL-H, PhMe, $-78{ }^{\circ} \mathrm{C}, 1 \mathrm{~h}$, then $\left[\mathrm{C}_{13} \mathrm{H}_{27} \mathrm{PPh}_{3}\right]^{+}[\mathrm{Br}]^{-}, \mathrm{BuLi}, 80{ }^{\circ} \mathrm{C}, 1 \mathrm{~h}$; (ii) $\mathrm{H}_{2}, \mathrm{Pd}(\mathrm{OH})_{2} / \mathrm{C}$, $\mathrm{HCl} / \mathrm{MeOH}$ (1.25 M), rt, $72 \mathrm{~h}$; (iii) $\mathrm{Ac}_{2} \mathrm{O}$, DMAP, pyridine, rt, $72 \mathrm{~h}$.

Elaboration of the diastereoisomeric, enantiopure $\beta, \gamma$-diamino ester $\mathbf{4 9}$ to the corresponding 3-deoxy3-aminosphingoid base was next explored. Treatment of an 87:13 mixture of $\mathbf{4 9}$ and $\mathbf{5 0}$ with TBAF followed by chromatography ${ }^{21}$ gave $\delta$-hydroxy ester $\mathbf{6 0}$ in $66 \%$ isolated yield and an impure sample of lactone $\mathbf{6 1}$ [of unknown configuration at C(3)] in $\sim 10 \%$ isolated yield (Scheme 12). ${ }^{21}$ The relative configuration within 60 was unambiguously established by single crystal X-ray diffraction analysis (Figure 4), ${ }^{15}$ with the absolute 
$(3 R, 4 R, \alpha S)$-configuration following from the known (S)-configuration of the $\alpha$-methylbenzyl stereocenter; in addition the determination of a Flack $x$ parameter ${ }^{16,17}$ for the structure of $+0.08(15)$ was consistent with this assignment. This analysis allowed both the relative and absolute configurations of both $\mathbf{4 9}$ and $\mathbf{5 0}$ to be assigned unambiguously. In addition, treatment of $\mathbf{6 0}$ with TIPSCl gave a sample of 49 as a single diastereoisomer (albeit in only 19\% isolated yield), thus confirming the homochirality of these two species. Lactonisation of $\delta$-hydroxy ester $\mathbf{6 0}$ was attempted under a range of conditions but in each case failed. The obduracy of $\mathbf{6 0}$ to undergo lactonisation (in contrast to its diastereoisomer 54) may be due to the large 1,2torsional strain that would unavoidably be experienced between the bulky amino moieties in the cyclic product (Scheme 12).

\section{SCHEME $12^{\mathrm{a}}$}

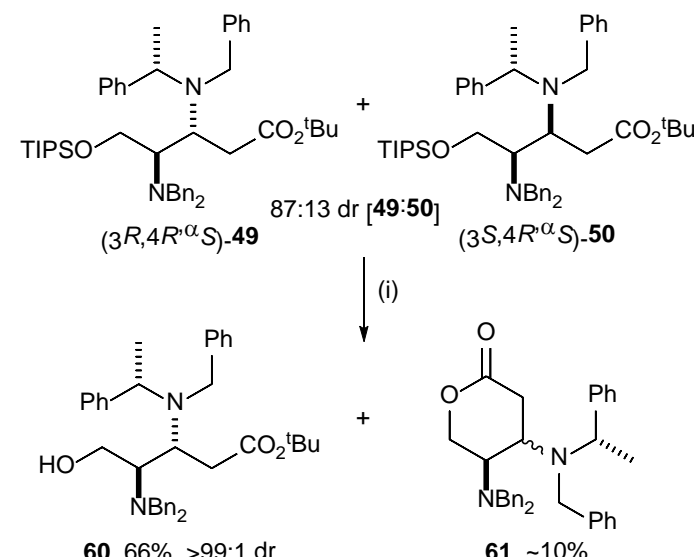

${ }^{\mathrm{a}}$ Reagents and conditions: (i) TBAF, THF, rt, 24 h.

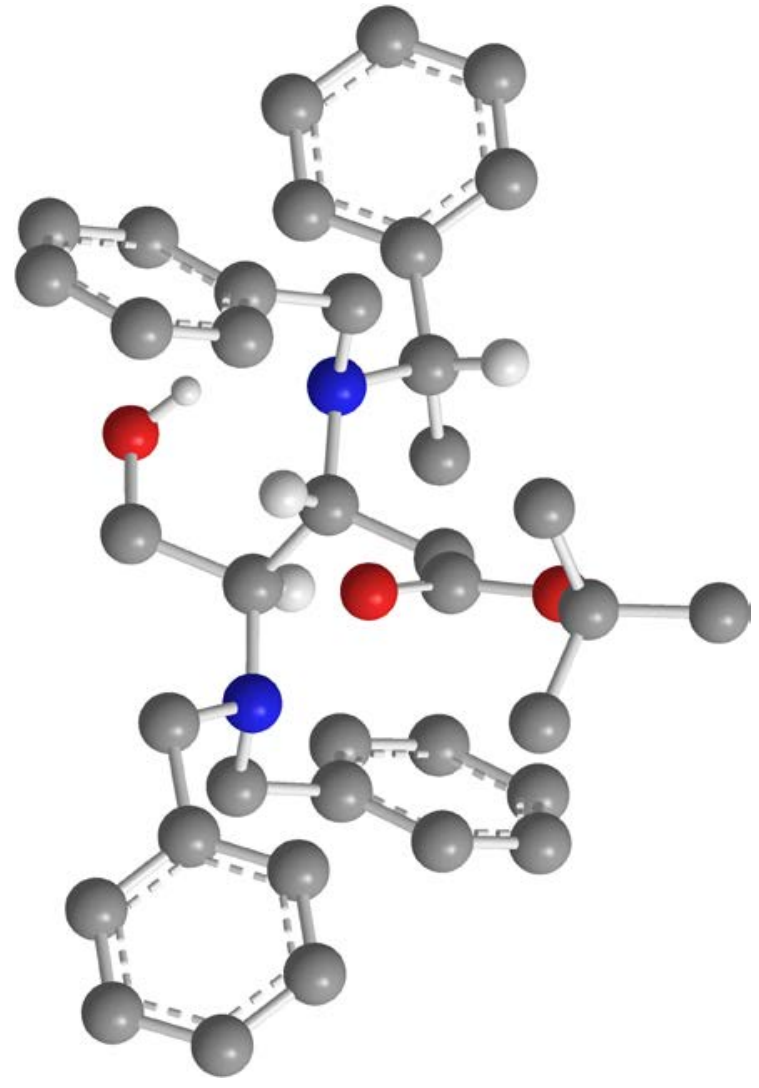

FIGURE 4. Chem3D representation of the X-ray crystal structure of $\mathbf{6 0}$ (selected H atoms are omitted for clarity). 
With lactonisation proving difficult, the possibility of effecting the chain elongation on an open chain system was next considered. Reduction of an 87:13 mixture of $\mathbf{4 9}$ and $\mathbf{5 0}$ gave an 87:13 mixture of the corresponding primary alcohol epimers 62 and 63, from which the major diastereoisomer 62 was isolated in 64\% yield after chromatography, although 63 was not isolated (Scheme 13). Attempted oxidation of 62 under a range of conditions resulted in extensive decomposition, consistent with the anticipated instability of the corresponding $\beta$-amino aldehyde. Hydrogenolysis of $\mathbf{6 2}$ in the presence of $\mathrm{Boc}_{2} \mathrm{O}$ gave the bis- $N$-Bocprotected analogue $\mathbf{6 4}$ in $82 \%$ yield, which similarly resulted in formation of a complex mixture of products upon its attempted oxidation under a range of conditions. The possibility of converting either $\mathbf{6 2}$ or $\mathbf{6 4}$ into the nucleophilic rather than electrophilic component for an ensuing Julia-Kocieński olefination ${ }^{22}$ was therefore assessed. Mitsunobu reaction of 62 with $N(1)$-phenyl-1H-tetrazole-5-thiol (PTSH) gave a mixture of unidentifiable products, presumably the result of participation of the amino groups. In contrast, Mitsunobu reaction of $\mathbf{6 4}$ with PTSH proceeded to give sulfide $\mathbf{6 6}$ in 60\% isolated yield. However, it proved more efficacious to proceed via the corresponding mesylate 65, which upon treatment with PTSH in the presence of $\mathrm{K}_{2} \mathrm{CO}_{3}$ provided sulfide 66 in an improved $81 \%$ yield (from 64). Subsequent oxidation of $\mathbf{6 6}$ with $\mathrm{H}_{2} \mathrm{O}_{2}$ in the presence of ammonium molybdate gave sulfone 67 in $93 \%$ yield. Julia-Kocieński olefination ${ }^{22}$ of tridecanal using sulfone $\mathbf{6 7}$ gave a 50:50 mixture of two compounds, $\mathbf{6 8}$ and $\mathbf{6 9}$, which were isolated in 80\% combined yield. Overlapping of peaks in the ${ }^{1} \mathrm{H}$ NMR spectra of both the crude and isolated products again frustrated ${ }^{3} J$ coupling constant analysis to establish that 68 and 69 were indeed related as olefin isomers; however, the ${ }^{13} \mathrm{C}$ NMR chemical shifts of the allylic carbon atoms $[C(4)$ and $C(7)]$ of both $\mathbf{6 8}$ and $\mathbf{6 9}$ were consistent with this assignment $\left(\gamma\right.$-effect), ${ }^{20}$ with 68 being assigned as the $(E)$-isomer and $\mathbf{6 9}$ as the $(Z)$ isomer. Hydrogenation of the 50:50 mixture of (E)-68 and (Z)-69 gave a single compound 70; treatment of 70 with TFA in $\mathrm{CH}_{2} \mathrm{Cl}_{2}$ effected removal of the $N$-Boc groups and was followed by $N$-acetylation, for ease of purification, giving 3-deoxy-3-aminosphingoid base derivative 71 in 72\% yield [from the 50:50 mixture of (E)-68 and (Z)-69]. Again, the convergence of the 50:50 mixture of (E)-68 and (Z)-69 into a single compound 71 in $72 \%$ yield provides further support to their assignment as olefin isomers. The overall yield of $\mathbf{7 1}$ was 14\% in fourteen steps from L-serine (Scheme 14). 


\section{SCHEME $13^{\text {a }}$}

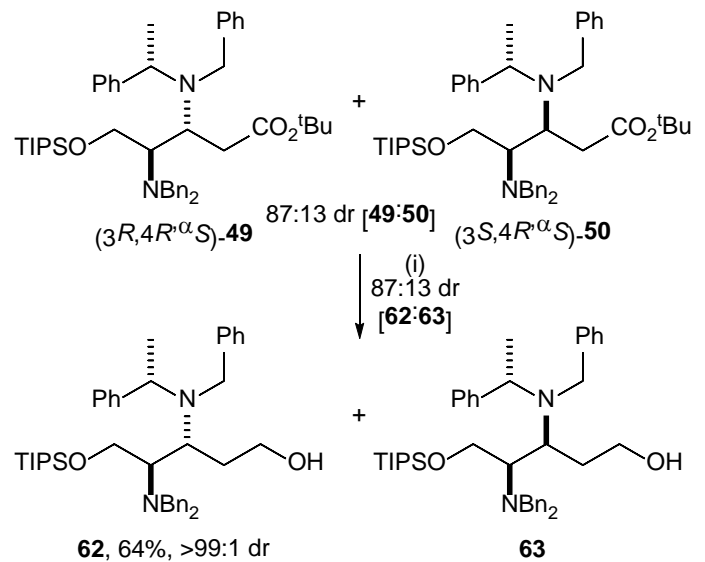

${ }^{a}$ Reagents and conditions: (i) $\mathrm{LiAlH}_{4}$, THF, rt, $18 \mathrm{~h}$.

\section{SCHEME $14^{a}$}
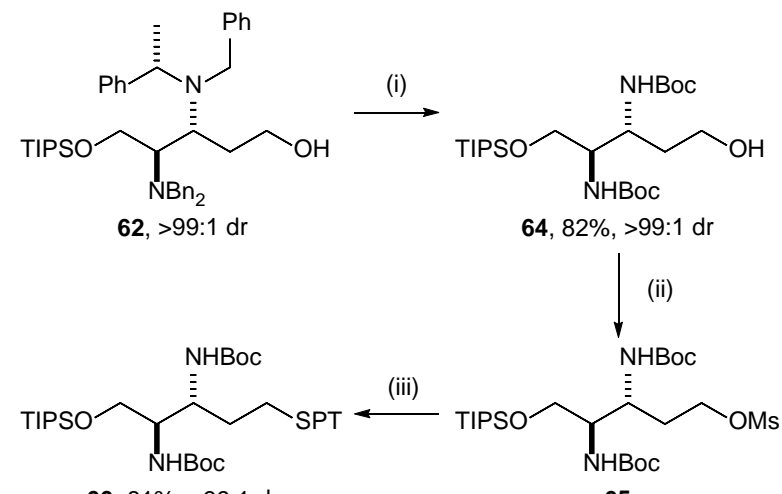

66, $81 \%,>99: 1 \mathrm{dr}$

65
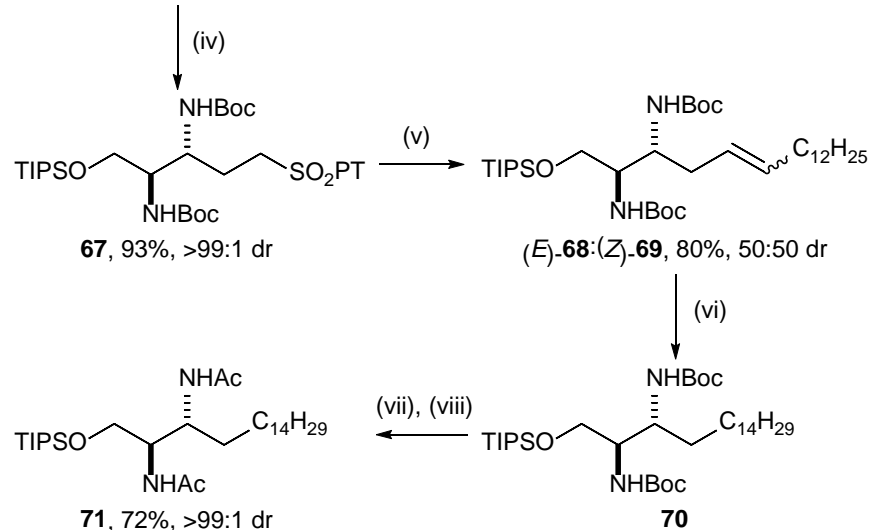

${ }^{a}$ Reagents and conditions: (i) $\mathrm{H}_{2}, \mathrm{Pd}(\mathrm{OH})_{2} / \mathrm{C}, \mathrm{Boc}_{2} \mathrm{O}, \mathrm{MeOH}$, rt, 72 h; (ii) $\mathrm{MsCl}, \mathrm{Et}_{3} \mathrm{~N}$, DMAP, $\mathrm{CH}_{2} \mathrm{Cl}_{2}$, rt, 3 h; (iii) PTSH, $\mathrm{K}_{2} \mathrm{CO}_{3}$, acetone, $67^{\circ} \mathrm{C}, 2.5 \mathrm{~h}$; (iv) $\mathrm{H}_{2} \mathrm{O}_{2}\left(30 \%\right.$ aq), $\left(\mathrm{NH}_{4}\right)_{2} \mathrm{Mo}_{7} \mathrm{O}_{24} \cdot 4 \mathrm{H}_{2} \mathrm{O}$, EtOH, rt, $18 \mathrm{~h}$; (v) LiHMDS, tridecanal, THF, rt, $18 \mathrm{~h}$; (vi) $\mathrm{H}_{2}$, $\mathrm{Pd} / \mathrm{C}, \mathrm{MeOH}$, rt, 3 h; (vii) TFA, $\mathrm{CH}_{2} \mathrm{Cl}_{2}$, rt, 18 h; (viii) $\mathrm{Ac}_{2} \mathrm{O}$, DMAP, pyridine, rt, 24 h.

Finally, the elaboration of enantiopure $\alpha$-hydroxy- $\beta, \gamma$-diamino ester $\mathbf{5 1}$ was considered. Under the conditions successfully employed for the one-pot $O$-desilylation/lactonisation of 47, treatment of 51 with TBAF gave $87 \%$ conversion to the corresponding lactone 73 (the intermediate $\alpha, \delta$-dihydroxy- $\beta, \gamma$-diamino ester 72 was not observed). Increasing the amount of TBAF resulted in $>95 \%$ conversion to 73 which was isolated in $61 \%$ yield after chromatography. In this case ${ }^{1} \mathrm{H}$ NMR ${ }^{3} J$ coupling constant analysis did not edify a likely conformational preference for $\mathbf{7 3}$. Although reduction of $\mathbf{7 3}$ with DIBAL-H gave a 50:50 mixture of the corresponding lactols $\mathbf{7 4}$, attempted Wittig reaction of $\mathbf{7 4}$ or attempted one-pot DIBAL-H/Wittig reaction of lactone $\mathbf{7 3}$ (under the optimised conditions used for the conversion of $\mathbf{5 5}$ into olefins $\mathbf{5 7}$ and $\mathbf{5 8}$, and under 
other conditions) resulted in incomplete consumption of starting material to form complex mixtures of products. An $O$-protecting group strategy was therefore implemented. $O$-Benzylation of $\mathbf{5 1}$ upon treatment with $\mathrm{NaH}$ and then $\mathrm{BnBr}$, gave 77 in 85\% yield. Subsequent treatment of $\mathbf{7 7}$ with TBAF gave a 39:61 mixture of diastereoisomeric lactones $\mathbf{7 9}$ and $\mathbf{8 0}$ which were isolated in 52\% combined yield. Alternative protocols for $O$-desilylation and lactonisation were investigated and whilst treatment of 77 with TBAF buffered with AcOH returned only starting material, exposure of $\mathbf{7 7}$ to $\mathrm{HF}$-pyridine gave $\delta$-hydroxy ester $\mathbf{7 8}$ in $77 \%$ yield. Treatment of $\mathbf{7 8}$ with $40 \%$ aq $\mathrm{HBF}_{4}$ for 48 h gave a somewhat complex mixture containing starting material $\mathbf{7 8}$ and lactone $\mathbf{7 9}$ as major components, with only a trace amount of lactone $\mathbf{8 0}$ being observed. Purification gave $\mathbf{7 8}$ in 30\% yield and a 50:50 mixture of $\mathbf{7 8}$ and $\mathbf{7 9}$ in 34\% combined calculated yield. In contrast, treatment of $\mathbf{7 8}$ with TBAF gave a 50:50 mixture of lactones $\mathbf{7 9}$ and $\mathbf{8 0}$, which were isolated in 52\% combined yield. Resubjection of the 50:50 mixture of $\mathbf{7 9}$ and $\mathbf{8 0}$ to these reaction conditions for a further 4 days gave a 13:87 mixture of lactones $\mathbf{7 9}$ and $\mathbf{8 0}$. Taken together, these results are consistent with $O$-desilylation of $\mathbf{7 7}$ under basic conditions being followed by lactonisation of the resultant $\delta$-hydroxy ester 78, and then epimerisation of the initially formed lactone $\mathbf{7 9}$ into $\mathbf{8 0}$. It is on the basis of this mechanistic postulate that the configurations of both $\mathbf{7 9}$ and $\mathbf{8 0}$ were assigned. Although it is apparent that cyclisation of $\mathbf{7 8}$ under acidic conditions did not result in competing epimerisation, this condition set is ineffective at promoting complete lactonisation. Attempted $O$-benzylation of lactone $\mathbf{7 3}$ proved similarly inefficacious at providing lactone 79: treatment of 73 with $\mathrm{NaH}$ and $\mathrm{BnBr}$ resulted in incomplete consumption of starting material to form of a complex mixture of products, with exhaustive chromatographic purification giving recovered 73 in 21\% yield and an 8:92 mixture of lactones $\mathbf{7 9}$ and $\mathbf{8 0}$ in 5\% combined yield (Scheme 15).

\section{SCHEME $15^{\mathrm{a}}$}

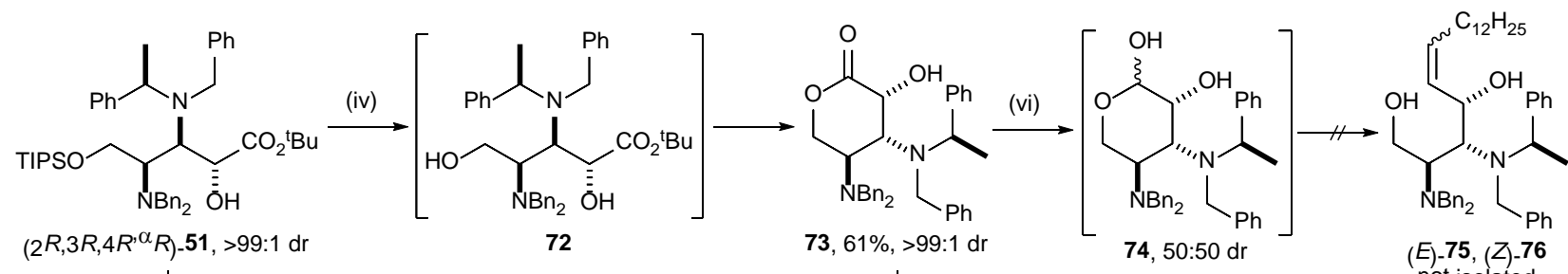

$$
\begin{array}{lll}
\text { (iv) } & \text { (ii) }
\end{array}
$$


${ }^{a}$ Reagents and conditions: (i) $\mathrm{NaH}$, THF, $0{ }^{\circ} \mathrm{C}, 30 \mathrm{~min}$, then $\mathrm{BnBr}, 0{ }^{\circ} \mathrm{C}$ to rt, $24 \mathrm{~h}$; (ii) $\mathrm{HF} \cdot \mathrm{pyridine}, \mathrm{THF}, \mathrm{rt}, 18 \mathrm{~h}$; (iii) $\mathrm{HBF}_{4}$ (40\% aq), $\mathrm{CH}_{2} \mathrm{Cl}_{2}$, rt, 48 h; (iv) TBAF, THF, rt, 24 h; (v) TBAF, THF, rt, 4 days; (vi) DIBAL-H, PhMe, $-78{ }^{\circ} \mathrm{C}, 1$ h. ${ }^{b} 79$ was isolated as a 50:50 mixture with unreacted starting material $\mathbf{7 8}$ from this reaction, in 34\% combined calculated yield.

With the lactonisation route again proving troublesome, the possibility of effecting the elaboration of 51 into the corresponding 3-deoxy-3-aminosphingoid base via an open chain form was investigated; in this instance however the synthesis would involve the intermediacy of an $\alpha$-oxy- $\beta$-amino aldehyde, which are much less susceptible to retro-conjugate addition than their $\alpha$-unsubstituted counterparts. Treatment of $\mathbf{7 7}$ with DIBAL-H gave alcohol 81 in $87 \%$ yield, with oxidation with IBX giving complete conversion to aldehyde 82. Purification of aldehyde $\mathbf{8 2}$ was not attempted, and it was instead immediately subjected to Wittig olefination using the ylide derived from $\left[\mathrm{C}_{13} \mathrm{H}_{27} \mathrm{PPh}_{3}\right]^{+}[\mathrm{Br}]^{-}$under the optimised conditions employed for the conversion of $\mathbf{5 5}$ into olefins $(E)-\mathbf{5 7}$ and (Z)-58, which resulted in formation of a complex mixture of products. When the reaction was run using THF as the solvent alone, a similarly complex mixture was formed although this time a 90:10 ratio of olefin $(Z)-\mathbf{8 6}\left({ }^{3} \mathrm{~J}=10.6 \mathrm{~Hz}\right)$ to starting material 82 was evident. It was again not possible to accurately assess the reaction diastereoselectivity due to peak overlap and the complexity of the ${ }^{1} \mathrm{H}$ NMR spectrum of the crude reaction mixture. Chromatography gave an impure sample of (Z)-86 in 35\% isolated yield and >95:5 dr. In contrast, Julia-Kocieński olefination ${ }^{22}$ of aldehyde 82 using sulfone 84 [prepared via $S$-alkylation of PTSH with 1-bromotridecane and then $S$-oxidation of the intermediate sulfide 83] delivered an 82:18 mixture of (E)-85 and (Z)-86 in 69\% combined yield. Peak overlap in the ${ }^{1} \mathrm{H}$ NMR spectrum did not allow ${ }^{3} J$ coupling constant analysis for the major component, although the known olefin geometry of (Z)-86 allowed its assignment as (E)-85; the ${ }^{13} \mathrm{C}$ NMR chemical shifts of the allylic carbon atoms [C(4) and $\mathrm{C}(7)]$ of both $(E)-85$ and $(Z)-\mathbf{8 6}$ were consistent with these assignments $\left(\gamma\right.$-effect) ${ }^{20}$ Treatment of the 82:18 mixture of $(E)-85$ and $(Z)-86$ with TBAF over 18 h resulted in incomplete conversion to an 82:18 mixture of the corresponding $O$-desilylated compounds $(E)-87$ and $(Z)$ 88, from which an 82:18 mixture of starting materials $(E)-85$ and $(Z)-86$ were isolated in 21\% combined yield, an 82:18 mixture of (E)-87 and (Z)-88 in 68\% combined yield. Although complete $O$-desilylation of (E)-85 and (Z)-86 was observed after a reaction time of $84 \mathrm{~h}$ (giving an 82:18 mixture of (E)-87 and (Z)-88 in 61\% combined yield), use of HF·pyridine effected complete $O$-desilylation of (E)-85 and (Z)-86 within 18 h to give an 82:18 mixture of (E)-87 and (Z)-88 in 86\% combined yield. Sufficient resonance dispersion in the ${ }^{1} \mathrm{H}$ NMR spectrum of this mixture allowed ${ }^{3} J$ coupling constant analysis of the major product $(E)-87$, which displayed ${ }^{3} J=15.7 \mathrm{~Hz}$ between the olefinic protons, consistent with the (E)-olefin geometry. A TOCSY experiment allowed decoupling of the allylic protons in the minor isomer (Z)-88 and revealed ${ }^{3} \mathrm{~J}=$ $10.9 \mathrm{~Hz}$ between the olefinic protons, consistent with the $(Z)$-olefin geometry. Once again, the ${ }^{13} \mathrm{C}$ NMR chemical shifts of the allylic carbon atoms $[C(4)$ and $C(7)]$ of both $(E)-87$ and $(Z)-88$ were consistent with 
these assignments $\left(\gamma\right.$-effect). ${ }^{20}$ Ensuing hydrogenolysis of the 82:18 mixture of $(E)-\mathbf{8 7}$ and $(Z)-\mathbf{8 8}$, and then peracetylation of the crude reaction mixture (for ease of purification) gave 3-deoxy-3-aminosphingoid base derivative $\mathbf{8 9}$ in 72\% yield and >99:1 dr. The overall yield of $\mathbf{8 9}$ was 15\% in thirteen steps from L-serine, or $3 \%$ (out of a theoretical maximum of 50\%) in thirteen steps from DL-serine. The major difference contributing to the superior efficiency of the former over the latter route reflects the differing proficiencies of the enolate oxidation steps (Scheme 16).

\section{SCHEME 16}

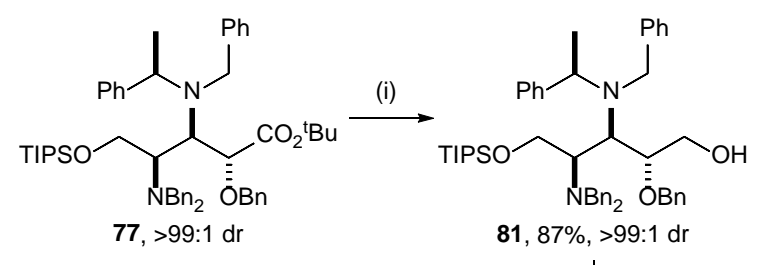

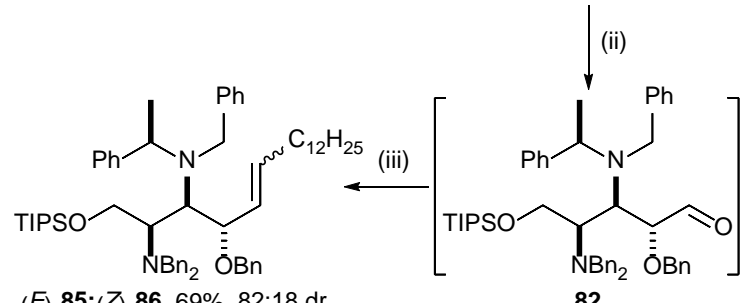
(E)-85:(Z)-86, 69\%, 82:18 dr

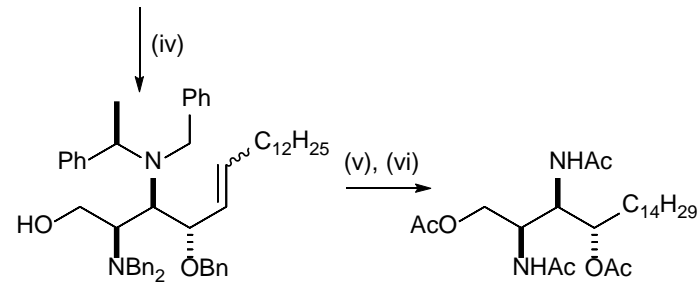
$(E)-87:(Z)-88,86 \%, 82: 18 d r$

89, $72 \%,>99: 1 d r$

$$
\begin{gathered}
\mathrm{C}_{13} \mathrm{H}_{27} \mathrm{Br} \stackrel{(\text { vii })}{\longrightarrow} \mathrm{C}_{13} \mathrm{H}_{27} \mathrm{SPT} \stackrel{(\text { viii) }}{\longrightarrow} \mathrm{C}_{13} \mathrm{H}_{27} \mathrm{SO}_{2} \mathrm{PT} \\
\mathbf{8 3}
\end{gathered}
$$

${ }^{a}$ Reagents and conditions: (i) DIBAL-H, PhMe, $-78^{\circ} \mathrm{C}$ to rt, $18 \mathrm{~h}$; (ii) IBX, DMSO, rt, 18 h; (iii) 84, LiHMDS, THF, rt, 18 h; (iv) HF. pyridine, THF, rt, $18 \mathrm{~h}$; (v) $\mathrm{H}_{2}, \mathrm{Pd}(\mathrm{OH})_{2} / \mathrm{C}, \mathrm{HCl}\left(1.25 \mathrm{M}\right.$ in MeOH), rt, $72 \mathrm{~h}$; (vi) $\mathrm{Ac}_{2} \mathrm{O}$, DMAP, pyridine, rt, $72 \mathrm{~h}$; (vii) $\mathrm{K}_{2} \mathrm{CO}_{3}$, PTSH, acetone, $65^{\circ} \mathrm{C}$, $2.5 \mathrm{~h}$; (viii) $\mathrm{H}_{2} \mathrm{O}_{2}(30 \% \mathrm{aq})$, $\left(\mathrm{NH}_{4}\right)_{2} \mathrm{Mo}_{7} \mathrm{O}_{24} \cdot 4 \mathrm{H}_{2} \mathrm{O}$, EtOH, rt, $18 \mathrm{~h}$.

\section{Conclusion}

In conclusion, the asymmetric syntheses of a range of $N$ - and $O$-protected 3-deoxy-3-aminosphingoid bases have been achieved from DL-serine and/or L-serine. The approach from DL-serine relies on the parallel kinetic resolution of a racemic $N, N$-dibenzyl-protected $\gamma$-amino- $\alpha, \beta$-unsaturated ester upon conjugate addition of a pseudoenantiomeric mixture of lithium $(R)-N$-benzyl- $N$-( $\alpha$-methylbenzyl)amide and lithium (S)- $N$-3,4-dimethoxybenzyl- $N$-( $\alpha$-methylbenzyl)amide, giving the corresponding enantio- and diastereoisomerically pure $\beta, \gamma$-diamino esters. The approach from L-serine relies on the doubly diastereoselective conjugate additions of the antipodes of lithium $N$-benzyl- $N$-( $\alpha$-methylbenzyl)amide to the same $N, N$-dibenzyl-protected $\gamma$-amino- $\alpha, \beta$-unsaturated ester but in enantiomerically pure form; in both cases 
the conjugate addition reactions proceed under the dominant stereocontrol of the lithium amide reagents to give the corresponding enantiomerically pure $\beta, \gamma$-diamino esters. The incorporation of an enolate oxidation (rather than protonation) into both of these protocols allows access to the corresponding $\alpha$-hydroxy- $\beta, \gamma$ diamino esters. The $\beta, \gamma$-diamino esters and $\alpha$-hydroxy- $\beta, \gamma$-diamino esters were then elaborated using the ester functionality as a synthetic handle to give protected forms of the corresponding 3-deoxy-3aminosphingoid bases.

\section{Experimental Section}

General Experimental Details. Reactions involving moisture-sensitive reagents were carried out under a nitrogen atmosphere using standard vacuum line techniques and glassware that was flame-dried and cooled under nitrogen before use. Solvents were dried according to the procedure outlined by Grubbs and co-workers. ${ }^{23}$ Organic layers were dried over $\mathrm{MgSO}_{4}$. Flash column chromatography was performed on Kieselgel 60 silica.

Melting points are uncorrected. Specific rotations are reported in $10^{-1} \mathrm{deg}_{\mathrm{cm}} \mathrm{g}^{-1}$ and concentrations in g/100 mL. IR spectra were recorded using an ATR module. Selected characteristic peaks are reported in $\mathrm{cm}^{-1}$. NMR spectra were recorded in the deuterated solvent stated. The field was locked by external referencing to the relevant deuteron resonance. ${ }^{1} \mathrm{H}-{ }^{1} \mathrm{H}$ COSY and ${ }^{1} \mathrm{H}-{ }^{13} \mathrm{C}$ HMQC analyses were used to establish atom connectivity. Accurate mass measurements were run on a MicroTOF instrument internally calibrated with polyalanine.

X-ray Crystal Structure Determination. ${ }^{15}$ Data were collected using graphite monochromated CuK $\alpha$ radiation using standard procedures at $150 \mathrm{~K}$. The structures were solved by direct methods (SIR92); all non-hydrogen atoms were refined with anisotropic thermal parameters. Hydrogen atoms were added at idealised positions. The structures were refined using CRYSTALS. ${ }^{24}$

Benzyl (RS)-2-( $N$, $N$-dibenzylamino)-3-hydroxypropanoate (RS)-38. $\mathrm{K}_{2} \mathrm{CO}_{3}(78.9 \mathrm{~g}, 572 \mathrm{mmol})$ and $\mathrm{BnBr}(67.9 \mathrm{ml}, 572 \mathrm{mmol})$ were added sequentially to a stirred solution of DL-serine (20.0 g, $190 \mathrm{mmol})$ in $\mathrm{H}_{2} \mathrm{O}(300 \mathrm{~mL})$ and the resultant solution was stirred at reflux for $18 \mathrm{~h}$. The resultant solution was allowed to cool to rt and then extracted with $\mathrm{Et}_{2} \mathrm{O}(3 \times 300 \mathrm{~mL})$. The combined organics were washed with brine (500 mL), dried and concentrated in vacuo. Vacuum distillation gave (RS)-38 as a pale yellow oil (39.6 g, $55 \%){ }^{25} \delta_{\mathrm{H}}\left(400 \mathrm{MHz}, \mathrm{CDCl}_{3}\right)$ 2.15-2.79 (1H, br s, OH), 3.57-3.69 (1H, m, C(3) $\left.\mathrm{H}_{\mathrm{A}}\right)$ overlapping $3.64(2 \mathrm{H}$, d, $J$ 13.5, $\left.\mathrm{N}\left(\mathrm{CH}_{\mathrm{A}} \mathrm{H}_{\mathrm{B}} \mathrm{Ph}\right)_{2}\right), 3.72-3.84\left(2 \mathrm{H}, \mathrm{m}, \mathrm{C}(2) H, \mathrm{C}(3) H_{\mathrm{B}}\right), 3.89\left(2 \mathrm{H}, \mathrm{d}, J 13.5, \mathrm{~N}\left(\mathrm{CH}_{\mathrm{A}} H_{\mathrm{B}} \mathrm{Ph}\right)_{2}\right), 5.23(1 \mathrm{H}$, d, $J$ 12.2, $\left.\mathrm{OCH}_{\mathrm{A}} \mathrm{H}_{\mathrm{B}} \mathrm{Ph}\right), 5.30$ (1H, d, $J$ 12.2, $\left.\mathrm{OCH}_{\mathrm{A}} H_{\mathrm{B}} \mathrm{Ph}\right), 7.22-7.44$ (15H, m, Ph). 
Benzyl (RS)-2-(N,N-dibenzylamino)-3-(triisopropylsilyloxy)propanoate (RS)-39. TIPSCl (1.03 g, $5.33 \mathrm{mmol}$ ) and imidazole (726 mg, $10.7 \mathrm{mmol})$ were added sequentially to a stirred solution of (RS)-38 (1.00 g, $2.67 \mathrm{mmol})$ in DMF (10 mL) and the resultant solution was stirred at rt for $18 \mathrm{~h}$. Brine $(10 \mathrm{~mL})$ was added and the aqueous layer was extracted with $\mathrm{CH}_{2} \mathrm{Cl}_{2}(3 \times 30 \mathrm{~mL})$. The combined organics were dried and concentrated in vacuo. Purification via flash column chromatography (eluent 30-40 ${ }^{\circ} \mathrm{C}$ petroleum ether/EtOAc, 30:1) gave (RS)-39 as a colourless oil (1.15 g, 81\%); $v_{\max } 1734(\mathrm{C}=\mathrm{O}) ; \delta_{\mathrm{H}}\left(500 \mathrm{MHz}, \mathrm{CDCl}_{3}\right)$ 0.95-1.05 (21H, m, Si(CHMe $\left.)_{3}\right)$ ), 3.60 (1H, app t, J 6.3, C(2)H), 3.67 (2H, d, $J$ 14.2, N(CHA $\left.\left.\mathrm{H}_{\mathrm{B}} \mathrm{Ph}\right)_{2}\right), 3.94$ (2H, d, $J$ 14.2, $\left.\mathrm{N}\left(\mathrm{CH}_{\mathrm{A}} H_{\mathrm{B}} \mathrm{Ph}\right)_{2}\right)$ overlapping 3.95-3.99 (1H, m, C(3)H $\left.H_{\mathrm{A}}\right), 4.12\left(1 \mathrm{H}, \mathrm{dd}, J\right.$ 10.7, 6.6, C(3)H $H_{\mathrm{B}}$, $5.14\left(1 \mathrm{H}, \mathrm{d}, J\right.$ 12.3, $\left.\mathrm{OCH}_{\mathrm{A}} \mathrm{H}_{\mathrm{B}} \mathrm{Ph}\right), 5.29$ (1H, d, $J$ 12.3, $\left.\mathrm{OCH}_{\mathrm{A}} H_{\mathrm{B}} \mathrm{Ph}\right), 7.19-7.43$ (15H, m, Ph); $\delta_{\mathrm{C}}(125 \mathrm{MHz}$, $\left.\mathrm{CDCl}_{3}\right) 11.9\left(\mathrm{Si}\left(\mathrm{CHMe}_{2}\right)_{3}\right), 17.9\left(\mathrm{Si}(\mathrm{CHMe})_{3}\right), 55.5\left(\mathrm{~N}\left(\mathrm{CH}_{2} \mathrm{Ph}\right)_{2}\right), 63.2(C(2)), 63.4(C(3)), 66.0\left(\mathrm{OCH}_{2} \mathrm{Ph}\right)$, 126.8, 126.9 (p-Ph), 128.2, 128.4, 128.5, 128.7 (o,m-Ph), 136.1, 139.8 (i-Ph), 171.4 (C(1)); m/z (ESI $) 554$ $\left([\mathrm{M}+\mathrm{Na}]^{+}, 96 \%\right), 532\left([\mathrm{M}+\mathrm{H}]^{+}, 100 \%\right)$; HRMS $\left(\mathrm{ESI}^{+}\right) \mathrm{C}_{33} \mathrm{H}_{46} \mathrm{NO}_{3} \mathrm{Si}^{+}\left([\mathrm{M}+\mathrm{H}]^{+}\right)$requires 532.3241; found 524.3241.

Methyl (RS)-2-amino-3-hydroxypropanoate hydrochloride (RS)-40. AcCl (2.03 mL, $28.6 \mathrm{mmol})$ was added dropwise to stirred $\mathrm{MeOH}(12 \mathrm{~mL})$ at $0{ }^{\circ} \mathrm{C}$ and the resultant solution was stirred at $0{ }^{\circ} \mathrm{C}$ for 15 min. DL-Serine (1.00 g, $9.52 \mathrm{mmol})$ was added portionwise and the resultant solution was stirred at reflux for $3 \mathrm{~h}$, then allowed to cool to rt and concentrated in vacuo. Recrystallization (MeOH) gave (RS)-40 as a white solid (1.26 g, 85\%); ${ }^{9} \mathrm{mp} \mathrm{130-132}{ }^{\circ} \mathrm{C} ; \delta_{\mathrm{H}}\left(400 \mathrm{MHz}, \mathrm{D}_{2} \mathrm{O}\right) 3.70$ (3H, s, OMe), 3.83 (1H, dd, $J$ 12.7, 3.5, $\left.\mathrm{C}(3) H_{\mathrm{A}}\right), 3.95\left(1 \mathrm{H}, \mathrm{dd}, J 12.7,4.1, \mathrm{C}(3) H_{\mathrm{B}}\right), 4.13(1 \mathrm{H}$, app t, $J$ 3.8, C(2)H).

Methyl (S)-2-amino-3-hydroxypropanoate hydrochloride (S)-40. AcCl (2.03 mL, $28.6 \mathrm{mmol}$ ) was added dropwise to stirred $\mathrm{MeOH}(12 \mathrm{~mL})$ at $0{ }^{\circ} \mathrm{C}$ and the resultant solution was stirred at $0{ }^{\circ} \mathrm{C}$ for $15 \mathrm{~min}$. $\mathrm{L}-$ Serine (1.00 g, $9.52 \mathrm{mmol})$ was added portionwise and the resultant solution was stirred at reflux for $3 \mathrm{~h}$, then allowed to cool to rt and concentrated in vacuo. Recrystallization (MeOH) gave (S)-40 as a white solid (1.34 g, 91\%); ${ }^{9} \mathrm{mp} 164-166{ }^{\circ} \mathrm{C} ;[\alpha]_{\mathrm{D}}^{20}+4.2($ c 1.0 in $\mathrm{MeOH})$.

Methyl (RS)-2-( $N$, $N$-dibenzylamino)-3-hydroxypropanoate (RS)-41. $\mathrm{K}_{2} \mathrm{CO}_{3}$ (2.89 g, 20.9 mmol) and $\mathrm{BnBr}(1.24 \mathrm{~mL}, 10.4 \mathrm{mmol})$ were added sequentially to a stirred solution of (RS)-40 (650 mg, 4.18 mmol) in $\mathrm{MeCN}(8 \mathrm{~mL})$ and the resultant solution was stirred at $\mathrm{rt}$ for $24 \mathrm{~h}$. $\mathrm{H}_{2} \mathrm{O}(10 \mathrm{~mL})$ was added and the aqueous layer was extracted with EtOAc $(3 \times 10 \mathrm{~mL})$. The combined organics were dried and concentrated in vacuo. Purification via flash column chromatography (eluent 30-40 ${ }^{\circ} \mathrm{C}$ petroleum ether/EtOAc, 8:1) gave $(R S)-41$ as a colourless oil (1.11 g, 89\%); ${ }^{9} \delta_{\mathrm{H}}\left(400 \mathrm{MHz}, \mathrm{CDCl}_{3}\right) 2.58(1 \mathrm{H}$, br s, OH), 3.59 (1H, dd, J 15.1, 7.6, C(3) $\left.\left.H_{\mathrm{A}}\right), 3.69\left(2 \mathrm{H}, \mathrm{d}, J \text { 13.4, N(CH} \mathrm{H}_{\mathrm{B}} \mathrm{Ph}\right)_{2}\right), 3.68-3.79\left(2 \mathrm{H}, \mathrm{m}, \mathrm{C}(2) H, \mathrm{C}(3) H_{\mathrm{B}}\right), 3.80(3 \mathrm{H}, \mathrm{s}, \mathrm{OMe})$, 3.91 (2H, d, J 13.4, N(CH$\left.\left.H_{\mathrm{B}} \mathrm{Ph}\right)_{2}\right), 7.20-7.39$ (10H, m, Ph). 
Methyl (S)-2-(N,N-dibenzylamino)-3-hydroxypropanoate (S)-41. $\mathrm{K}_{2} \mathrm{CO}_{3}(2.89 \mathrm{~g}, 20.9 \mathrm{mmol})$ and $\mathrm{BnBr}(1.24 \mathrm{~mL}, 10.4 \mathrm{mmol})$ were added sequentially to a stirred solution of $(S)-40$ (650 mg, $4.18 \mathrm{mmol})$ in MeCN (8 mL) and the resultant solution was stirred at rt for $24 \mathrm{~h} . \mathrm{H}_{2} \mathrm{O}(10 \mathrm{~mL})$ was added and the aqueous layer was extracted with EtOAc $(3 \times 10 \mathrm{~mL})$. The combined organics were dried and concentrated in vacuo. Purification via flash column chromatography (eluent 30-40 ${ }^{\circ} \mathrm{C}$ petroleum ether/EtOAc, 8:1) gave $(S)-\mathbf{4 1}$ as a colourless oil $(1.16 \mathrm{~g}, 93 \%) ;{ }^{9}[\alpha]_{\mathrm{D}}^{20}-167.1$ (c 1.0 in $\left.\mathrm{CHCl}_{3}\right)$.

Methyl (RS)-2-(N,N-dibenzylamino)-3-(triisopropylsilyloxy)propanoate (RS)-42. Method A. From (RS)-41. TIPSCl (644 mg, $3.34 \mathrm{mmol}$ ) and imidazole (455 mg, $6.68 \mathrm{mmol}$ ) were added sequentially to a stirred solution of $(R S)-41$ (500 mg, $1.67 \mathrm{mmol})$ in DMF (10 mL) and the resultant solution was stirred at rt for $18 \mathrm{~h}$. Brine (5 mL) was added and the aqueous layer was extracted with $\mathrm{CH}_{2} \mathrm{Cl}_{2}(3 \times 15 \mathrm{~mL})$. The combined organics were dried and concentrated in vacuo. Purification via flash column chromatography (eluent $30-40{ }^{\circ} \mathrm{C}$ petroleum ether/EtOAc, 30:1) gave (RS)-42 as a colourless oil (661 mg, 87\%); $v_{\max } 1738$ $(\mathrm{C}=\mathrm{O}) ; \delta_{\mathrm{H}}\left(400 \mathrm{MHz}, \mathrm{CDCl}_{3}\right)$ 0.95-1.07 (21H, m, Si(CHMe $\left.)_{3}\right), 3.57$ (1H, app t, J 6.0, C(2)H), 3.70 (2H, d, $J$ 14.2, N(CH $\left.\left.\mathrm{CH}_{\mathrm{B}} \mathrm{Ph}\right)_{2}\right), 3.75$ (3H, s, OMe), 3.93-4.01 (3H, m, N(CH $\left.\left.\mathrm{CH}_{\mathrm{B}} \mathrm{Ph}\right)_{2}, \mathrm{C}(3) H_{\mathrm{A}}\right), 4.10$ (1H, dd, $J$ 9.9, 6.5, C(3)H $\left.H_{\mathrm{B}}\right), 7.19-7.43(10 \mathrm{H}, \mathrm{m}, \mathrm{Ph}) ; \delta_{\mathrm{C}}\left(100 \mathrm{MHz} \mathrm{CDCl}_{3}\right) 11.9\left(\mathrm{Si}\left(\mathrm{CHMe}_{2}\right)_{3}\right), 17.9\left(\mathrm{Si}(\mathrm{CHMe})_{3}\right), 51.1$ (OMe), $55.5\left(\mathrm{~N}\left(\mathrm{CH}_{2} \mathrm{Ph}\right)_{2}\right), 63.3$ (C(2), C(3)), 126.9 (p-Ph), 128.2, 128.7 (o,m-Ph), 139.9 (i-Ph), $172.1 \mathrm{C}(1)$;

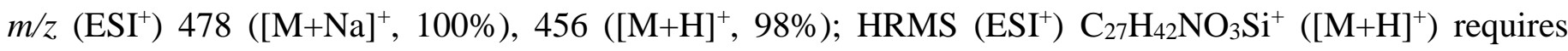
456.2928; found 456.2925.

Method B. Telescoped Procedure from DL-Serine. Step 1. AcCl (7.1 mL, $99.9 \mathrm{mmol})$ was added dropwise to stirred $\mathrm{MeOH}(40 \mathrm{~mL})$ at $0{ }^{\circ} \mathrm{C}$ and the resultant solution was stirred at $0{ }^{\circ} \mathrm{C}$ for $15 \mathrm{~min}$. DLSerine (3.50 g, $33.3 \mathrm{mmol}$ ) was added portionwise and the resultant solution was stirred at reflux for $3 \mathrm{~h}$, then allowed to cool to rt and concentrated in vacuo to give (RS)-40 as a white solid (5.29 g).

Step 2. $\mathrm{K}_{2} \mathrm{CO}_{3}(23.0 \mathrm{~g}, 166 \mathrm{mmol})$ and $\mathrm{BnBr}(9.89 \mathrm{~mL}, 83.3 \mathrm{mmol})$ were added sequentially to a stirred solution of the residue $(R S)-40$ (5.29 g) from the previous step in MeCN (80 mL) and the resultant solution was stirred at rt for $24 \mathrm{~h} . \mathrm{H}_{2} \mathrm{O}(100 \mathrm{~mL})$ was added and the aqueous layer was extracted with EtOAc $(3 \times 100 \mathrm{~mL})$. The combined organics were dried and concentrated in vacuo to give $(R S)-\mathbf{4 1}$ as a yellow oil (11.2 g).

Step 3. TIPSCl (12.8 g, $66.6 \mathrm{mmol})$ and imidazole (9.07 g, $133 \mathrm{mmol})$ were added sequentially to a stirred solution of the residue $(R S)-41$ (11.2 g) from the previous step in DMF (30 mL) and the resultant solution was stirred at rt for $18 \mathrm{~h}$. Brine $(60 \mathrm{~mL})$ was added and the aqueous layer was extracted with $\mathrm{CH}_{2} \mathrm{Cl}_{2}(3 \times 300 \mathrm{~mL})$. The combined organics were dried and concentrated in vacuo. Purification via flash 
column chromatography (eluent $30-40{ }^{\circ} \mathrm{C}$ petroleum ether/EtOAc, 30:1) gave (RS)-42 as a colourless oil (12.4 g, 82\%).

Methyl (S)-2-(N,N-dibenzylamino)-3-(triisopropylsilyloxy)propanoate (S)-42. Method A. From (S)-41. TIPSCl (644 mg, $3.34 \mathrm{mmol}$ ) and imidazole (455 mg, $6.68 \mathrm{mmol}$ ) were added sequentially to a stirred solution of (S)-41 (500 mg, $1.67 \mathrm{mmol})$ in DMF (10 mL) and the resultant solution was stirred at rt for $18 \mathrm{~h}$. Brine $(10 \mathrm{~mL})$ was added and the aqueous layer was extracted with $\mathrm{CH}_{2} \mathrm{Cl}_{2}(3 \times 15 \mathrm{~mL})$. The combined organics were dried and concentrated in vacuo. Purification via flash column chromatography (eluent $30-40{ }^{\circ} \mathrm{C}$ petroleum ether/EtOAc, 30:1) gave (S)-42 as a colourless oil (676 mg, 89\%); $[\alpha]_{\mathrm{D}}^{20}-44.2$ (c 1.0 in $\mathrm{CHCl}_{3}$ ).

Method B. Telescoped Procedure from L-Serine. Step 1. AcCl (10.1 mL, $143 \mathrm{mmol})$ was added dropwise to stirred $\mathrm{MeOH}(60 \mathrm{~mL})$ at $0{ }^{\circ} \mathrm{C}$ and the resultant solution was stirred at $0{ }^{\circ} \mathrm{C}$ for $15 \mathrm{~min}$. L-Serine (5.00 g, $47.6 \mathrm{mmol}$ ) was added portionwise and the resultant solution was stirred at reflux for $3 \mathrm{~h}$, then allowed to cool to rt and concentrated in vacuo to give $(S)-\mathbf{4 0}$ as a white solid (7.21 g).

Step 2. $\mathrm{K}_{2} \mathrm{CO}_{3}(32.9 \mathrm{~g}, 238 \mathrm{mmol})$ and $\mathrm{BnBr}(14.1 \mathrm{~mL}, 119 \mathrm{mmol})$ were added sequentially to a stirred solution of the residue (S)-40 (7.21 g) from the previous step in MeCN (120 mL) and the resultant solution was stirred at rt for $24 \mathrm{~h} . \mathrm{H}_{2} \mathrm{O}(150 \mathrm{~mL})$ was added and the aqueous layer was extracted with EtOAc $(3 \times 300 \mathrm{~mL})$. The combined organics were dried and concentrated in vacuo to give $(S)-\mathbf{4 1}$ as a yellow oil (27.8 g).

Step 3. TIPSCl (18.3 g, $94.9 \mathrm{mmol})$ and imidazole (12.9 g, $189 \mathrm{mmol})$ were added sequentially to a stirred solution of the residue $(S)-\mathbf{4 1}(27.8 \mathrm{~g})$ from the previous step in DMF (140 $\mathrm{mL}$ ) and the resultant solution was stirred at rt for $18 \mathrm{~h}$. Brine (200 mL) was added and the aqueous layer was extracted with $\mathrm{CH}_{2} \mathrm{Cl}_{2}(3 \times 300 \mathrm{~mL})$. The combined organics were dried and concentrated in vacuo. Purification via flash column chromatography (eluent $30-40{ }^{\circ} \mathrm{C}$ petroleum ether/EtOAc, 30:1) gave $(S)-42$ as a colourless oil (18.8 g, 87\%); $[\alpha]_{\mathrm{D}}^{20}-43.1$ (c 1.0 in $\left.\mathrm{CHCl}_{3}\right)$.

(RS)-2-(N,N-Dibenzylamino)-3-(triisopropylsilyloxy)propan-1-ol (RS)-43. Method A. From (RS)39. DIBAL-H (1.0 M in PhMe, $2.35 \mathrm{~mL}, 2.35 \mathrm{mmol})$ was added dropwise to a stirred solution of (RS)-39 (500 mg, $0.940 \mathrm{mmol}$ ) in $\mathrm{PhMe}(2 \mathrm{~mL})$ at $-78{ }^{\circ} \mathrm{C}$ and the resultant solution was stirred at $-78{ }^{\circ} \mathrm{C}$ for $1 \mathrm{~h}$. $\mathrm{MeOH}(1 \mathrm{~mL})$ was added dropwise and the resultant solution was allowed to warm to rt, then diluted with $\mathrm{CH}_{2} \mathrm{Cl}_{2}(15 \mathrm{~mL})$ and satd aq Rochelle salt $(15 \mathrm{~mL})$. The resultant biphasic mixture was stirred vigorously at rt for $18 \mathrm{~h}$ and then the aqueous layer was extracted with $\mathrm{CH}_{2} \mathrm{Cl}_{2}(3 \times 15 \mathrm{~mL})$. The combined organics were dried and concentrated in vacuo. Purification via flash column chromatography (eluent $30-40{ }^{\circ} \mathrm{C}$ petroleum ether/Et $\left.{ }_{2} \mathrm{O}, 20: 1\right)$ gave $(R S)-43$ as a colourless oil (350 mg, 87\%); $v_{\max } 3451(\mathrm{O}-\mathrm{H}) ; \delta_{\mathrm{H}}\left(500 \mathrm{MHz}, \mathrm{CDCl}_{3}\right)$ 
1.05-1.17 (21H, m, Si(CHMe $\left.)_{3}\right)$, 2.93 (1H, br s, OH), $3.03(1 \mathrm{H}, \mathrm{m}, \mathrm{C}(2) H)$, 3.57-3.65 (2H, m, C(1)H $\mathrm{H}_{2}$, $3.68\left(2 \mathrm{H}, \mathrm{d}, J\right.$ 13.6, $\left.\mathrm{N}\left(\mathrm{CH}_{\mathrm{A}} \mathrm{H}_{\mathrm{B}} \mathrm{Ph}\right)_{2}\right), 3.83$ (1H, dd, $J$ 10.4, 6.3, C(3) $\left.H_{\mathrm{A}}\right), 3.91\left(2 \mathrm{H}, \mathrm{d}, J 13.6, \mathrm{~N}\left(\mathrm{CH}_{\mathrm{A}} H_{\mathrm{B}} \mathrm{Ph}\right)_{2}\right)$, $3.97\left(1 \mathrm{H}, \mathrm{dd}, 10.4,6.0, \mathrm{C}(3) H_{\mathrm{B}}\right), 7.22-7.34(10 \mathrm{H}, \mathrm{m}, \mathrm{Ph}) ; \delta_{\mathrm{C}}\left(125 \mathrm{MHz}, \mathrm{CDCl}_{3}\right) 11.7\left(\mathrm{Si}\left(\mathrm{CHMe}_{2}\right)_{3}\right), 17.7$ (Si(CHMe $\left.)_{3}\right)$, $54.1\left(\mathrm{~N}\left(\mathrm{CH}_{2} \mathrm{Ph}\right)_{2}\right), 59.8$ (C(1)), 60.0 (C(2)), $61.5(C(3)), 127.1(p-P h), 128.4,128.9(o, m-P h)$, $139.9(\mathrm{i}-\mathrm{Ph}) ; \mathrm{m} / \mathrm{z}\left(\mathrm{ESI}^{+}\right) 450\left([\mathrm{M}+\mathrm{Na}]^{+}, 100 \%\right), 428\left([\mathrm{M}+\mathrm{H}]^{+}, 98 \%\right) ; \mathrm{HRMS}\left(\mathrm{ESI}^{+}\right) \mathrm{C}_{26} \mathrm{H}_{42} \mathrm{NO}_{2} \mathrm{Si}^{+}\left([\mathrm{M}+\mathrm{H}]^{+}\right)$ requires 428.2979; found 428.2975 .

Method B. From (RS)-42. DIBAL-H (1.0 M in PhMe, $1.65 \mathrm{~mL}, 1.65 \mathrm{mmol})$ was added dropwise to a stirred solution of $(R S)-42$ (300 mg, $0.658 \mathrm{mmol})$ in $\mathrm{PhMe}(2 \mathrm{~mL})$ at $-78{ }^{\circ} \mathrm{C}$ and the resultant solution was stirred at $-78^{\circ} \mathrm{C}$ for $1 \mathrm{~h}$. $\mathrm{MeOH}(1 \mathrm{~mL})$ was added dropwise and the resultant solution was allowed to warm to rt, then diluted with $\mathrm{CH}_{2} \mathrm{Cl}_{2}(15 \mathrm{~mL})$ and satd aq Rochelle salt (15 mL). The resultant biphasic mixture was stirred vigorously at $\mathrm{rt}$ for $18 \mathrm{~h}$ and then the aqueous layer was extracted with $\mathrm{CH}_{2} \mathrm{Cl}_{2}(3 \times 15 \mathrm{~mL})$. The combined organics were dried and concentrated in vacuo. Purification via flash column chromatography (eluent $30-40{ }^{\circ} \mathrm{C}$ petroleum ether/Et $2 \mathrm{O}, 20: 1$ ) gave $(R S)-43$ as a colourless oil (221 mg, 78\%).

(R)-2-( $N, N$-Dibenzylamino)-3-(triisopropylsilyloxy)propan-1-ol $(\boldsymbol{R})-43$. DIBAL-H $(1.0 \mathrm{M}$ in PhMe, $1.10 \mathrm{~mL}, 1.10 \mathrm{mmol})$ was added dropwise to a stirred solution of (S)-42 (200 mg, $0.439 \mathrm{mmol})$ in PhMe (2 mL) at $-78{ }^{\circ} \mathrm{C}$ and the resultant solution was stirred at $-78{ }^{\circ} \mathrm{C}$ for $1 \mathrm{~h}$. $\mathrm{MeOH}(1 \mathrm{~mL})$ was added dropwise and the resultant solution was allowed to warm to rt, then diluted with $\mathrm{CH}_{2} \mathrm{Cl}_{2}(15 \mathrm{~mL})$ and satd aq Rochelle salt $(15 \mathrm{~mL})$. The resultant biphasic mixture was stirred vigorously at rt for $18 \mathrm{~h}$ and then the aqueous layer was extracted with $\mathrm{CH}_{2} \mathrm{Cl}_{2}(3 \times 15 \mathrm{~mL})$. The combined organics were dried and concentrated in vacuo. Purification via flash column chromatography (eluent $30-40{ }^{\circ} \mathrm{C}$ petroleum ether/Et $2 \mathrm{O}, 20: 1$ ) gave (R)-43 as a colourless oil (128 mg, 68\%); $[\alpha]_{\mathrm{D}}^{20}-50.2$ (c 1.0 in $\left.\mathrm{CHCl}_{3}\right)$.

tert-Butyl (RS,E)-4-(N,N-dibenzylamino)-5-(triisopropylsilyloxy)pent-2-enoate (RS)-44. Method A. From (RS)-43. A solution of DMSO $(97 \mu \mathrm{L}, 1.37 \mathrm{mmol})$ in $\mathrm{CH}_{2} \mathrm{Cl}_{2}(5 \mathrm{~mL})$ at $-78{ }^{\circ} \mathrm{C}$ was added dropwise to a stirred solution of $(\mathrm{COCl})_{2}(108 \mu \mathrm{L}, 1.26 \mathrm{mmol})$ in $\mathrm{CH}_{2} \mathrm{Cl}_{2}(5 \mathrm{~mL})$ at $-78{ }^{\circ} \mathrm{C}$, and the resultant solution was stirred at $-78{ }^{\circ} \mathrm{C}$ for $10 \mathrm{~min}$. A solution of $(R S)-43$ (450 mg, $\left.1.05 \mathrm{mmol}\right)$ in $\mathrm{CH}_{2} \mathrm{Cl}_{2}(5 \mathrm{~mL})$ at $-78{ }^{\circ} \mathrm{C}$ was then added dropwise via cannula and the resultant solution was stirred at $-78{ }^{\circ} \mathrm{C}$ for $1 \mathrm{~h}$. Et $\mathrm{t}_{3} \mathrm{~N}(293 \mu \mathrm{L}$, $2.10 \mathrm{mmol}$ ) was then added dropwise and the resultant solution was allowed to warm to rt. $\mathrm{Ph}_{3} \mathrm{P}=\mathrm{CHCO}_{2}{ }^{\mathrm{t}} \mathrm{Bu}$ (395 mg, $1.05 \mathrm{mmol}$ ) was then added and the resultant solution was stirred at rt for $18 \mathrm{~h}$. The resultant solution was washed with satd aq $\mathrm{Na}_{2} \mathrm{CO}_{3}(20 \mathrm{~mL})$ and the aqueous layer was extracted with $\mathrm{CH}_{2} \mathrm{Cl}_{2}(3 \times 25$ $\mathrm{mL}$ ). The combined organics were dried and concentrated in vacuo. Purification via flash column chromatography (eluent $30-40{ }^{\circ} \mathrm{C}$ petroleum ether/Et $\left.2 \mathrm{O}, 30: 1\right)$ gave $(R S)-44$ as a pale yellow oil (395 mg, 72\%, >99:1 dr [(E):(Z) ratio]); $v_{\max } 1714(\mathrm{C}=\mathrm{O}), 1650(\mathrm{C}=\mathrm{C}) ; \delta_{\mathrm{H}}\left(500 \mathrm{MHz}, \mathrm{CDCl}_{3}\right)$ 1.00-1.06 (21H, m, 
Si(CHMe $\left.)_{3}\right), 1.51$ (9H, s, CMe 3 ), 3.42 (1H, m, C(4)H), 3.64 (2H, d, J 13.9, N(CHA $\left.\left.\mathrm{CH}_{\mathrm{B}} \mathrm{Ph}\right)_{2}\right) 3.82-3.91$ (3H, m, C(5) $\left.H_{\mathrm{A}}, \mathrm{N}\left(\mathrm{CH}_{\mathrm{A}} H_{\mathrm{B}} \mathrm{Ph}\right)_{2}\right), 3.94-3.99$ (1H, dd, $J$ 10.1, 6.9, C(5)HB $), 5.95$ (1H, dd, $J$ 15.8, 1.3, C(2)H), 6.97 (1H, dd, $J$ 15.8, 6.9, C(3)H), 7.19-7.41 (10H, m, Ph); $\delta_{\mathrm{C}}\left(125 \mathrm{MHz}, \mathrm{CDCl}_{3}\right) 28.1\left(\mathrm{CMe}_{3}\right), 54.7\left(\mathrm{~N}\left(\mathrm{CH}_{2} \mathrm{Ph}\right)_{2}\right)$, 60.7 (C(4)), 64.0 (C(5)), $80.3\left(\mathrm{CMe}_{3}\right), 126.8$ (p-Ph), 128.2, 128.5 (o,m-Ph), $140.0(\mathrm{i}-\mathrm{Ph}) 125.6(C(2)), 144.7$ (C(3)), $165.7(C(1)) ; m / z\left(\mathrm{ESI}^{+}\right) 546\left([\mathrm{M}+\mathrm{Na}]^{+}, 15 \%\right), 524\left([\mathrm{M}+\mathrm{H}]^{+}, 100 \%\right) ; \mathrm{HRMS}\left(\mathrm{ESI}^{+}\right) \mathrm{C}_{32} \mathrm{H}_{50} \mathrm{NO}_{3} \mathrm{Si}^{+}$ $\left([\mathrm{M}+\mathrm{H}]^{+}\right)$requires 524.3554; found 524.3556.

Method B. Telescoped Procedure from (RS)-42. Step 1. DIBAL-H (1.0 M in PhMe, 68.1 mL, 68.1 mmol) was added dropwise to a stirred solution of (RS)-42 (12.4 g, $27.2 \mathrm{mmol})$ in $\mathrm{PhMe}(80 \mathrm{~mL})$ at $-78{ }^{\circ} \mathrm{C}$ and the resultant solution was stirred at $-78^{\circ} \mathrm{C}$ for $1 \mathrm{~h}$. $\mathrm{MeOH}(40 \mathrm{~mL})$ was added dropwise and the resultant solution was allowed to warm to rt, then diluted with $\mathrm{CH}_{2} \mathrm{Cl}_{2}(300 \mathrm{~mL})$ and satd aq Rochelle salt (300 mL). The resultant biphasic mixture was stirred vigorously at rt for $18 \mathrm{~h}$ and then the aqueous layer was extracted with $\mathrm{CH}_{2} \mathrm{Cl}_{2}(3 \times 300 \mathrm{~mL})$. The combined organics were dried and concentrated in vacuo to give $(R S)-43$ as a colourless oil (11.4 g).

Step 2. A solution of DMSO (2.51 mL, $35.4 \mathrm{mmol})$ in $\mathrm{CH}_{2} \mathrm{Cl}_{2}(10 \mathrm{~mL})$ at $-78{ }^{\circ} \mathrm{C}$ was added dropwise to a stirred solution of $(\mathrm{COCl})_{2}(2.80 \mathrm{~mL}, 32.7 \mathrm{mmol})$ in $\mathrm{CH}_{2} \mathrm{Cl}_{2}(100 \mathrm{~mL})$ at $-78{ }^{\circ} \mathrm{C}$, and the resultant solution was stirred at $-78{ }^{\circ} \mathrm{C}$ for $10 \mathrm{~min}$. A solution of the residue $(R S)-43(11.4 \mathrm{~g})$ from the previous step in $\mathrm{CH}_{2} \mathrm{Cl}_{2}(50 \mathrm{~mL})$ at $-78{ }^{\circ} \mathrm{C}$ was then added dropwise via cannula and the resultant solution was stirred at $-78{ }^{\circ} \mathrm{C}$ for $1 \mathrm{~h}$. $\mathrm{Et}_{3} \mathrm{~N}(7.59 \mathrm{~mL}, 54.4 \mathrm{mmol})$ was then added dropwise and the resultant solution was allowed to warm to rt. $\mathrm{Ph}_{3} \mathrm{P}=\mathrm{CHCO}_{2}{ }^{\mathrm{t}} \mathrm{Bu}(10.2 \mathrm{~g}, 27.2 \mathrm{mmol})$ was then added and the resultant solution was stirred at rt for $18 \mathrm{~h}$. The resultant solution was washed with satd aq $\mathrm{Na}_{2} \mathrm{CO}_{3}(200 \mathrm{~mL})$ and the aqueous layer was extracted with $\mathrm{CH}_{2} \mathrm{Cl}_{2}(3 \times 300 \mathrm{~mL})$. The combined organics were dried and concentrated in vacuo. Purification via flash column chromatography (eluent $30-40{ }^{\circ} \mathrm{C}$ petroleum ether/Et $2 \mathrm{O}, 30: 1$ ) gave $(R S)-44$ as a pale yellow oil (11.2 g, 79\%, >99:1 dr [(E):(Z) ratio]).

tert-Butyl (R,E)-4-(N,N-dibenzylamino)-5-(triisopropylsilyloxy)pent-2-enoate (R)-44. Method A. From (R)-43. A solution of DMSO $(21.6 \mu \mathrm{L}, 0.304 \mathrm{mmol})$ in $\mathrm{CH}_{2} \mathrm{Cl}_{2}(1 \mathrm{~mL})$ at $-78{ }^{\circ} \mathrm{C}$ was added dropwise to a stirred solution of $(\mathrm{COCl})_{2}(24.1 \mu \mathrm{L}, 0.281 \mathrm{mmol})$ in $\mathrm{CH}_{2} \mathrm{Cl}_{2}(1 \mathrm{~mL})$ at $-78{ }^{\circ} \mathrm{C}$, and the resultant solution was stirred at $-78{ }^{\circ} \mathrm{C}$ for $10 \mathrm{~min}$. A solution of $(R)-43(100 \mathrm{mg}, 0.233 \mathrm{mmol})$ in $\mathrm{CH}_{2} \mathrm{Cl}_{2}(1 \mathrm{~mL})$ at $-78{ }^{\circ} \mathrm{C}$ was then added dropwise via cannula and the resultant solution was stirred at $-78{ }^{\circ} \mathrm{C}$ for $1 \mathrm{~h}$. Et $3 \mathrm{~N}$ (65.2 $\mu \mathrm{L}, 0.468 \mathrm{mmol}$ ) was then added dropwise and the resultant solution was allowed to warm to rt. $\mathrm{Ph}_{3} \mathrm{P}=\mathrm{CHCO}_{2}{ }^{\mathrm{t}} \mathrm{Bu}(88.0 \mathrm{mg}, 0.233 \mathrm{mmol})$ was then added and the resultant solution was stirred at rt for $18 \mathrm{~h}$. The resultant solution was washed with satd aq $\mathrm{Na}_{2} \mathrm{CO}_{3}(2 \mathrm{~mL})$ and the aqueous layer was extracted with $\mathrm{CH}_{2} \mathrm{Cl}_{2}(3 \times 5 \mathrm{~mL})$. The combined organics were dried and concentrated in vacuo. Purification via flash 
column chromatography (eluent $30-40{ }^{\circ} \mathrm{C}$ petroleum ether/Et $\left.2 \mathrm{O}, 30: 1\right)$ gave $(R)-44$ as a pale yellow oil (106 mg, 88\%, >99:1 dr [(E):(Z) ratio]); $[\alpha]_{\mathrm{D}}^{20}-16.0$ (c 1.0 in $\left.\mathrm{CHCl}_{3}\right)$.

Method B. Telescoped Procedure from (S)-42. Step 1. DIBAL-H (1.0 M in PhMe, 103 mL, 103 mmol) was added dropwise to a stirred solution of (S)-42 (18.8 g, $41.3 \mathrm{mmol})$ in PhMe $(80 \mathrm{~mL})$ at $-78{ }^{\circ} \mathrm{C}$ and the resultant solution was stirred at $-78{ }^{\circ} \mathrm{C}$ for $1 \mathrm{~h}$. $\mathrm{MeOH}(40 \mathrm{~mL})$ was added dropwise and the resultant solution was allowed to warm to rt, then diluted with $\mathrm{CH}_{2} \mathrm{Cl}_{2}(300 \mathrm{~mL})$ and satd aq Rochelle salt (300 mL). The resultant biphasic mixture was stirred vigorously at $\mathrm{rt}$ for $18 \mathrm{~h}$ and then the aqueous layer was extracted with $\mathrm{CH}_{2} \mathrm{Cl}_{2}(3 \times 300 \mathrm{~mL})$. The combined organics were dried and concentrated in vacuo to give $(R)-\mathbf{4 3}$ as a colourless oil (17.6 g).

Step 2. A solution of DMSO (3.81 mL, $53.6 \mathrm{mmol})$ in $\mathrm{CH}_{2} \mathrm{Cl}_{2}(20 \mathrm{~mL})$ at $-78{ }^{\circ} \mathrm{C}$ was added dropwise to a stirred solution of $(\mathrm{COCl})_{2}(4.25 \mathrm{~mL}, 49.5 \mathrm{mmol})$ in $\mathrm{CH}_{2} \mathrm{Cl}_{2}(100 \mathrm{~mL})$ at $-78{ }^{\circ} \mathrm{C}$, and the resultant solution was stirred at $-78{ }^{\circ} \mathrm{C}$ for $10 \mathrm{~min}$. A solution of the residue $(R)-43$ (17.6 g) from the previous step in $\mathrm{CH}_{2} \mathrm{Cl}_{2}(50 \mathrm{~mL})$ at $-78{ }^{\circ} \mathrm{C}$ was then added dropwise via cannula and the resultant solution was stirred at $-78^{\circ} \mathrm{C}$ for $1 \mathrm{~h}$. $\mathrm{Et}_{3} \mathrm{~N}(11.5 \mathrm{~mL}, 82.5 \mathrm{mmol})$ was then added dropwise and the resultant solution was allowed to warm to rt. $\mathrm{Ph}_{3} \mathrm{P}=\mathrm{CHCO}_{2}{ }^{\mathrm{t}} \mathrm{Bu}(15.5 \mathrm{~g}, 41.3 \mathrm{mmol})$ was then added and the resultant solution was stirred at rt for $18 \mathrm{~h}$. The resultant solution was washed with satd aq $\mathrm{Na}_{2} \mathrm{CO}_{3}(200 \mathrm{~mL})$ and the aqueous layer was extracted with $\mathrm{CH}_{2} \mathrm{Cl}_{2}(3 \times 300 \mathrm{~mL})$. The combined organics were dried and concentrated in vacuo. Purification via flash column chromatography (eluent $30-40{ }^{\circ} \mathrm{C}$ petroleum ether/Et $2 \mathrm{O}, 30: 1$ ) gave $(R)-44$ as a pale yellow oil (18.7 g, 87\%, >99:1 dr [(E):(Z) ratio], 99\% ee); $[\alpha]_{\mathrm{D}}^{20}-28.0$ (c 1.0 in $\left.\mathrm{CHCl}_{3}\right)$.

(RS)-44 was analysed by chiral HPLC, giving complete resolution of enantiomers (Chiralpak AD-H; mobile phase hexane; flow rate $\left.1.0 \mathrm{~mL} / \mathrm{min} ;(S)-44 t_{R}=7.78 \mathrm{~min} ;(R)-44 t_{R}=8.76 \mathrm{~min}\right)$. The sample of $(R)$ 44 was thence assessed to be $99 \%$ ee.

tert-Butyl

(RS,SR)-3-( $N$-benzyl- $N$-isopropylamino)-4-( $N, N$-dibenzylamino)-5(triisopropylsilyloxy)pentanoate 45. Substrate Control. BuLi (2.2 M in hexanes, $0.34 \mathrm{~mL}, 0.75 \mathrm{mmol})$ was added dropwise to a stirred solution of $N$-benzyl- $N$-isopropylamine (114 mg, $0.764 \mathrm{mmol}$ ) in THF (3 mL) at $-78{ }^{\circ} \mathrm{C}$ and the resultant solution was stirred at $-78{ }^{\circ} \mathrm{C}$ for $30 \mathrm{~min}$. A solution of (RS)-44 (200 mg, 0.382 mmol, $>99: 1 \mathrm{dr}[(E):(Z)$ ratio] $)$ in $\operatorname{THF}(1.5 \mathrm{~mL})$ at $-78^{\circ} \mathrm{C}$ was added dropwise via cannula and the resultant solution was stirred at $-78{ }^{\circ} \mathrm{C}$ for $2 \mathrm{~h}$. Satd aq $\mathrm{NH}_{4} \mathrm{Cl}(1 \mathrm{~mL})$ was then added and the resultant solution was allowed to warm to rt and then concentrated in vacuo. The residue was suspended in $10 \%$ aq citric acid (10 $\mathrm{mL})$ and extracted with $\mathrm{CH}_{2} \mathrm{Cl}_{2}(3 \times 25 \mathrm{~mL})$. The combined organics were washed sequentially with satd aq $\mathrm{NaHCO}_{3}(10 \mathrm{~mL})$ and brine $(10 \mathrm{~mL})$, then dried and concentrated in vacuo to give a 96:4 mixture of 45 and 46, respectively. Purification via flash column chromatography (eluent $30-40{ }^{\circ} \mathrm{C}$ petroleum ether/EtOAc, 
20:1) gave an impure sample of 46 as a colourless oil (5 mg, <5\%); $v_{\max } 1723(\mathrm{C}=\mathrm{O}) ; \delta_{\mathrm{H}}\left(500 \mathrm{MHz}, \mathrm{CDCl}_{3}\right)$ 0.94 (3H, d, J 6.0, NCHMe $\left.e_{\mathrm{A}}\right), 1.01$ (3H, d, $J$ 6.6, NCHMe $\left.e_{\mathrm{B}}\right), 1.15-1.24$ (21H, m, Si(CHMe $\left.)_{3}\right), 1.47$ (9H, s, $\left.\mathrm{CMe}_{3}\right), 2.09$ (1H, dd, $J$ 16.7, 6.3, C(2)H $\mathrm{A}_{\mathrm{A}}, 2.62-2.73(1 \mathrm{H}, \mathrm{m}, \mathrm{NCHMe}), 2.81(1 \mathrm{H}, \mathrm{m}, \mathrm{C}(4) H), 3.10(1 \mathrm{H}, \mathrm{dd}$, $J$ 16.7, 3.2, C(2)HB $H_{\mathrm{B}}$, 3.18-3.36 (2H, m, C(3)H, $\left.\mathrm{NCH}_{\mathrm{A}} \mathrm{H}_{\mathrm{B}} \mathrm{Ph}\right), 3.40$ (1H, d, $J$ 14.5, $\left.\mathrm{NCH}_{\mathrm{A}} H_{\mathrm{B}} \mathrm{Ph}\right), 3.70-3.96$ (5H, m, C(5)H $\left.\mathrm{H}_{\mathrm{A}} \mathrm{N}\left(\mathrm{CH}_{2} \mathrm{Ph}\right)_{2}\right), 4.25-4.39\left(1 \mathrm{H}, \mathrm{m}, \mathrm{C}(5) H_{\mathrm{B}}\right), 7.16-7.30(15 \mathrm{H}, \mathrm{m}, \mathrm{Ph}) ; \delta_{\mathrm{C}}\left(125 \mathrm{MHz}, \mathrm{CDCl}_{3}\right)$ $12.0\left(\mathrm{Si}\left(\mathrm{CHMe}_{2}\right)_{3}\right), 18.1\left(\mathrm{NCHMe}_{\mathrm{A}}\right), 18.3$ (Si(CHMe$\left.)_{3}\right), 22.5(\mathrm{NCHMe}), 28.2\left(\mathrm{CMe}_{3}\right), 34.6(C(2)), 48.3$ (NCHMe $), 50.0\left(\mathrm{NCH}_{2} \mathrm{Ph}\right), 53.8(C(3)), 54.6\left(\mathrm{~N}\left(\mathrm{CH}_{2} \mathrm{Ph}\right)_{2}\right), 59.8(C(4)), 65.6(C(5)), 80.0\left(C \mathrm{Me}_{3}\right), 126.4$, 126.5 (p-Ph), 127.9, 127.9, 128.7, 129.6 (o,m-Ph), 140.6, 141.2 (i-Ph), 173.9 (C(1)); m/z (ESI $) 695$ $\left([\mathrm{M}+\mathrm{Na}]^{+}, 36 \%\right), 673\left([\mathrm{M}+\mathrm{H}]^{+}, 100 \%\right) ; \mathrm{HRMS}\left(\mathrm{ESI}^{+}\right) \mathrm{C}_{42} \mathrm{H}_{65} \mathrm{~N}_{2} \mathrm{O}_{3} \mathrm{Si}^{+}\left([\mathrm{M}+\mathrm{H}]^{+}\right)$requires 673.4759; found 673.4761. Further elution gave 45 as a colourless oil $(145 \mathrm{mg}, 57 \%,>99: 1 \mathrm{dr}) ; v_{\max } 1724(\mathrm{C}=\mathrm{O})$; $\delta_{\mathrm{H}}(500$ $\left.\mathrm{MHz}, \mathrm{CDCl}_{3}\right) 0.94$ (3H, d, J 6.6, $\mathrm{NCHMe}_{\mathrm{A}}$ ) overlapping 0.96 (3H, d, J 6.6, $\left.\mathrm{NCHMe}_{\mathrm{B}}\right), 1.11-1.24$ (21H, m, $\left.\mathrm{Si}(\mathrm{CHMe})_{3}\right), 1.44$ (9H, s, CMe $\left.e_{3}\right), 2.51$ (1H, dd, $J$ 15.8, 4.7, C(2)H $\left.H_{\mathrm{A}}\right), 2.71\left(1 \mathrm{H}, \mathrm{dd}, J 15.8,6.9, \mathrm{C}(2) H_{\mathrm{B}}\right), 2.91$ (1H, septet, $J$ 6.6, $\mathrm{NCHMe}$ ), 3.00 (1H, m, C(4)H), 3.52 (1H, d, $J$ 15.0, $\mathrm{NCH}_{\mathrm{A}} \mathrm{H}_{\mathrm{B}} \mathrm{Ph}$ ) overlapping 3.54-3.59 (1H, m, C(3)H), 3.64 (2H, d, $J$ 14.0, N(CHA $\left.\left.\mathrm{H}_{\mathrm{B}} \mathrm{Ph}\right)_{2}\right), 3.71$ (1H, d, $J$ 15.0, $\left.\mathrm{NCH}_{\mathrm{A}} H_{\mathrm{B}} \mathrm{Ph}\right), 3.84$ (2H, d, $J$ 14.0, $\left.\mathrm{N}\left(\mathrm{CH}_{\mathrm{A}} H_{\mathrm{B}} \mathrm{Ph}\right)_{2}\right), 3.92\left(1 \mathrm{H}, \mathrm{dd}, J 10.4,6.9, \mathrm{C}(5) H_{\mathrm{A}}\right), 4.12\left(1 \mathrm{H}, \mathrm{dd}, J 10.4,6.9, \mathrm{C}(5) H_{\mathrm{B}}\right), 7.17-7.33(15 \mathrm{H}, \mathrm{m}$, $\left.P h) ; \delta_{\mathrm{C}}\left(125 \mathrm{MHz}, \mathrm{CDCl}_{3}\right) 12.0\left(\mathrm{Si}\left(\mathrm{CHMe}_{2}\right)_{3}\right), 18.2,18.3\left(\mathrm{Si}\left(\mathrm{CHMe}_{2}\right)_{3}, \mathrm{NCHMe}\right)_{\mathrm{A}}\right), 22.0\left(\mathrm{NCHMe}_{\mathrm{B}}\right), 28.1$ (CMe $)$, 34.9 (C(2)), $49.0\left(\mathrm{NCHMe}_{2}\right) 50.4\left(\mathrm{NCH}_{2} \mathrm{Ph}\right), 55.4\left(\mathrm{~N}\left(\mathrm{CH}_{2} \mathrm{Ph}\right)_{2}\right), 56.5$ (C(3)), 62.1 (C(5)), 63.8 (C(4)), 80.1 (CMe $)$, 126.0, 126.5 (p-Ph), 127.8, 128.0, 128.2, 128.9 (o,m-Ph), 140.5, 141.5 (i-Ph), 172.8 $(C(1)) ; \mathrm{m} / \mathrm{z}\left(\mathrm{ESI}^{+}\right) 695\left([\mathrm{M}+\mathrm{Na}]^{+}, 13 \%\right), 673\left([\mathrm{M}+\mathrm{H}]^{+}, 100 \%\right) ; \mathrm{HRMS}\left(\mathrm{ESI}^{+}\right) \mathrm{C}_{42} \mathrm{H}_{65} \mathrm{~N}_{2} \mathrm{O}_{3} \mathrm{Si}^{+}\left([\mathrm{M}+\mathrm{H}]^{+}\right)$ requires 673.4759; found 673.4758 .

tert-Butyl (3RS,4SR, $\alpha S R)-3-[N$-benzyl- $N$-( $\alpha$-methylbenzyl)amino]-4-( $N, N$-dibenzylamino)-5(triisopropylsilyloxy)pentanoate (3RS,4SR,aSR)-47. Mutual Kinetic Resolution. BuLi (2.2 M in hexanes, $0.34 \mathrm{~mL}, 0.75 \mathrm{mmol}$ ) was added dropwise to a stirred solution of (RS)- $N$-benzyl- $N$-( $\alpha$-methylbenzyl)amine (161 mg, $0.764 \mathrm{mmol})$ in THF $(3 \mathrm{~mL})$ at $-78^{\circ} \mathrm{C}$ and the resultant solution was stirred at $-78{ }^{\circ} \mathrm{C}$ for $30 \mathrm{~min}$. A solution of $(R S)-44$ (200 mg, $0.382 \mathrm{mmol},>99: 1 \mathrm{dr}\left[(E):(Z)\right.$ ratio]) in THF $(1.5 \mathrm{~mL})$ at $-78{ }^{\circ} \mathrm{C}$ was added dropwise via cannula and the resultant solution was stirred at $-78{ }^{\circ} \mathrm{C}$ for $2 \mathrm{~h}$. Satd aq $\mathrm{NH}_{4} \mathrm{Cl}(1 \mathrm{~mL})$ was then added and the resultant solution was allowed to warm to rt and then concentrated in vacuo. The residue was suspended in $10 \%$ aq citric acid $(10 \mathrm{~mL})$ and extracted with $\mathrm{CH}_{2} \mathrm{Cl}_{2}(3 \times 25 \mathrm{~mL})$. The combined organics were washed sequentially with satd aq $\mathrm{NaHCO}_{3}(10 \mathrm{~mL})$ and brine $(10 \mathrm{~mL})$, then dried and concentrated in vacuo. Purification via flash column chromatography (eluent $30-40{ }^{\circ} \mathrm{C}$ petroleum ether/EtOAc, 25:1) gave (3RS,4SR, $\alpha S R)-47$ as a colourless oil (223 mg, 80\%, >99:1 dr); $\mathrm{C}_{47} \mathrm{H}_{66} \mathrm{~N}_{2} \mathrm{O}_{3} \mathrm{Si}$ requires C, 76.8; $\mathrm{H}, 9.05 ; \mathrm{N}$, 3.8\%; found $\mathrm{C}, 76.9 ; \mathrm{H}, 9.0 ; \mathrm{N}, 3.9 \% ; v_{\max } 1721(\mathrm{C}=\mathrm{O}) ; \delta_{\mathrm{H}}\left(500 \mathrm{MHz}, \mathrm{CDCl}_{3}\right) 1.00-1.17(21 \mathrm{H}, \mathrm{m}$, 
Si(CHMe $\left.)_{3}\right), 1.30-1.36$ (12H, m, C( $\left.\left.\alpha\right) M e, C M e_{3}\right), 1.78$ (1H, dd, $J$ 16.4, 2.5, C(2)H $\left.H_{\mathrm{A}}\right), 2.55$ (1H, dd, $J$ 16.4, 8.8, C(2)H $\left.H_{\mathrm{B}}\right), 2.96-3.01(1 \mathrm{H}, \mathrm{m}, \mathrm{C}(4) H), 3.39\left(1 \mathrm{H}, \mathrm{d}, J\right.$ 15.8, $\left.\mathrm{NCH}_{\mathrm{A}} \mathrm{H}_{\mathrm{B}} \mathrm{Ph}\right), 3.57$ (2H, d, J 13.9, $\left.\mathrm{N}\left(\mathrm{CH}_{\mathrm{A}} \mathrm{H}_{\mathrm{B}} \mathrm{Ph}\right)_{2}\right)$, 3.63-3.72 (2H, m, C(3)H, C( $\left.\left.\alpha\right) H\right)$, 3.85-3.95 (4H, m, C(5) $\left.H_{\mathrm{A}}, \mathrm{NCH}_{\mathrm{A}} H_{\mathrm{B}} \mathrm{Ph}, \mathrm{N}\left(\mathrm{CH}_{\mathrm{A}} H_{\mathrm{B}} \mathrm{Ph}\right)_{2}\right)$, 4.17 (1H, dd, $J$ 10.4, 5.7, C(5)Hв), 6.91-6.95 (2H, m, Ph), 7.05-7.12 (3H, m, Ph), 7.18-7.31 (15H, m, Ph); $\delta_{\mathrm{C}}\left(125 \mathrm{MHz}_{\mathrm{CDCl}}\right) 11.9\left(\mathrm{Si}\left(\mathrm{CHMe}_{2}\right)_{3}\right), 18.2\left(\mathrm{Si}\left(\mathrm{CHM} e_{2}\right)_{3}\right), 20.6(\mathrm{C}(\alpha) M e), 28.0\left(\mathrm{CMe}_{3}\right), 33.3(\mathrm{C}(2))$, 51.4 ( $\left.\mathrm{NCH}_{2} \mathrm{Ph}\right)$, $55.3\left(\mathrm{~N}\left(\mathrm{CH}_{2} \mathrm{Ph}\right)_{2}\right), 56.4(C(3))$, $58.4(C(\alpha)), 61.3(C(5)), 64.6(C(4)), 79.9\left(C \mathrm{Me}_{3}\right), 125.8,126.6$, 126.8, 127.5, 127.9, 127.9, 128.0, 128.3, 129.0 (o,m,p-Ph), 140.5, 141.5, 142.7 (i-Ph), 172.4 (C(1)); m/z $\left(\mathrm{ESI}^{+}\right) 757\left([\mathrm{M}+\mathrm{Na}]^{+}, 100 \%\right), 735\left([\mathrm{M}+\mathrm{H}]^{+}, 100 \%\right) ; \mathrm{HRMS}\left(\mathrm{ESI}^{+}\right) \mathrm{C}_{47} \mathrm{H}_{67} \mathrm{~N}_{2} \mathrm{O}_{3} \mathrm{Si}^{+}\left([\mathrm{M}+\mathrm{H}]^{+}\right)$requires 735.4915; found 735.4909.

tert-Butyl

(3S,4R,aR)-3-[N-benzyl- $N$-( $\alpha$-methylbenzyl)amino]-4-( $N, N$-dibenzylamino)-5(triisopropylsilyloxy)pentanoate $(3 S, 4 R, \alpha R)-47$ and tert-butyl $(3 R, 4 S, \alpha S)-3-\left[N-3^{\prime}, 4^{\prime}\right.$-dimethoxybenzyl$N$-( $\alpha$-methylbenzyl)amino]-4-( $N, N$-dibenzylamino)-5-(triisopropylsilyloxy)pentanoate $\quad(3 R, 4 S, \alpha S)-48$. Parallel Kinetic Resolution. BuLi (2.2 M in hexanes, $0.34 \mathrm{~mL}, 0.75 \mathrm{mmol}$ ) was added dropwise to a stirred solution of $(R)-N$-benzyl- $N$-( $\alpha$-methylbenzyl)amine (80.7 mg, $0.382 \mathrm{mmol},>99 \%$ ee) and $(S)-N-3,4-$ dimethoxybenzyl- $N$-( $\alpha$-methylbenzyl)amine (104 mg, $0.382 \mathrm{mmol}$, $>99 \%$ ee) in THF (3 mL) at $-78{ }^{\circ} \mathrm{C}$ and the resultant solution was stirred at $-78^{\circ} \mathrm{C}$ for $30 \mathrm{~min}$. A solution of (RS)-44 (200 mg, $0.382 \mathrm{mmol},>99: 1 \mathrm{dr}$ [(E):(Z) ratio]) in THF $(1.5 \mathrm{~mL})$ at $-78^{\circ} \mathrm{C}$ was added dropwise via cannula and the resultant solution was stirred at $-78{ }^{\circ} \mathrm{C}$ for $2 \mathrm{~h}$. Satd aq $\mathrm{NH}_{4} \mathrm{Cl}(1 \mathrm{~mL})$ was then added and the resultant solution was allowed to warm to rt and then concentrated in vacuo. The residue was suspended in 10\% aq citric acid (10 mL) and extracted with $\mathrm{CH}_{2} \mathrm{Cl}_{2}(3 \times 25 \mathrm{~mL})$. The combined organics were washed sequentially with satd aq $\mathrm{NaHCO}_{3}$ $(10 \mathrm{~mL})$ and brine $(10 \mathrm{~mL})$, then dried and concentrated in vacuo to give a 50:50 mixture of $(3 S, 4 R, \alpha R)-47$ and $(3 R, 4 S, \alpha S)-48$. Purification via flash column chromatography (eluent 30-40 ${ }^{\circ} \mathrm{C}$ petroleum ether/EtOAc, 25:1; increased to $30-40{ }^{\circ} \mathrm{C}$ petroleum ether/EtOAc, 5:1) gave (3S,4R, $\left.\alpha R\right)-\mathbf{4 7}$ as a colourless oil (121 mg, 43\%, >99:1 dr); $[\alpha]_{\mathrm{D}}^{20}-0.7$ (c 1.0 in $\left.\mathrm{CHCl}_{3}\right)$. Further elution gave $(3 R, 4 S, \alpha S)-48$ as a colourless oil (106 mg, 35\%, >99:1 dr); $\mathrm{C}_{49} \mathrm{H}_{70} \mathrm{~N}_{2} \mathrm{O}_{5} \mathrm{Si}$ requires C, 74.0; H, 8.9; N, 3.5\%; found C, 73.9; H, 8.9; N, 3.6\%; $[\alpha]_{D}^{20}+3.0$ (c 1.0 in $\left.\mathrm{CHCl}_{3}\right)$; $v_{\max } 1723(\mathrm{C}=\mathrm{O})$; $\delta_{\mathrm{H}}\left(500 \mathrm{MHz}, \mathrm{CDCl}_{3}\right)$ 1.05-1.19 (21H, m, Si(CHMe $\left.)_{3}\right), 1.31(9 \mathrm{H}, \mathrm{s}$, CMe $), 1.38$ (3H, d, $J$ 6.9, C( $\alpha) M e), 1.72\left(1 \mathrm{H}, \mathrm{dd}, J\right.$ 16.4, 8.2, C(2)H $\left.H_{\mathrm{A}}\right), 2.46\left(1 \mathrm{H}, \mathrm{dd}, J 16.4,8.2, \mathrm{C}(2) H_{\mathrm{B}}\right)$, $3.01(1 \mathrm{H}, \mathrm{m}, \mathrm{C}(4) H), 3.41$ (1H, d, $J$ 15.8, $\left.\mathrm{NCH}_{\mathrm{A}} \mathrm{H}_{\mathrm{B}} \mathrm{Ar}\right), 3.60-3.73\left(4 \mathrm{H}, \mathrm{m}, \mathrm{C}(3) H, \mathrm{C}(\alpha) H, \mathrm{~N}\left(\mathrm{CH}_{\mathrm{A}} \mathrm{H}_{\mathrm{B}} \mathrm{Ph}\right)_{2}\right)$ overlapping 3.71 (3H, s, OMe), 3.78-3.94 (4H, m, C(5) $\left.H_{\mathrm{A}}, \mathrm{NCH}_{\mathrm{A}} \mathrm{H}_{\mathrm{B}} \mathrm{Ar}, \mathrm{N}\left(\mathrm{CH}_{\mathrm{A}} \mathrm{H}_{\mathrm{B}} \mathrm{Ph}\right)_{2}\right)$ overlapping 3.83 (3H, s, OMe), 4.21 (1H, dd, J 10.4, 6.9, C(5)HB), 6.54-6.58 (2H, m, Ar), 6.63 (1H, d, J 7.9, Ar), 7.15-7.31 (15H, m, Ph); $\delta_{\mathrm{C}}\left(125 \mathrm{MHz}, \mathrm{CDCl}_{3}\right) 12.0\left(\mathrm{Si}\left(\mathrm{CHMe}_{2}\right)_{3}\right), 18.2\left(\mathrm{Si}\left(\mathrm{CHMe}_{2}\right)_{3}\right), 19.8(\mathrm{C}(\alpha) M e), 28.0\left(\mathrm{CMe}_{3}\right)$, $33.6(C(2))$, $50.9\left(\mathrm{NCH}_{2} \mathrm{Ar}\right)$, 55.4, 55.6, 55.7 (C( $\left.(\alpha), \mathrm{OMe}\right), 55.8\left(\mathrm{~N}\left(\mathrm{CH}_{2} \mathrm{Ph}\right)_{2}\right), 58.1(C(3)), 62.5(C(5)), 63.5$ 
(C(4)), $79.8\left(C \mathrm{Me}_{3}\right), 110.6,110.8,119.5,126.5,126.8,127.9,128.0,128.3,128.8\left(C\left(2^{\prime}\right), C\left(5^{\prime}\right), C\left(6^{\prime}\right), o, m, p-\right.$ $\mathrm{Ph}), 133.7,140.4,142.5,147.1,148.5\left(C\left(1^{\prime}\right), C\left(3^{\prime}\right), C\left(4^{\prime}\right), i-P h\right), 172.1(C(1)) ; \mathrm{m} / \mathrm{z}\left(\mathrm{ESI}^{+}\right) 817\left([\mathrm{M}+\mathrm{Na}]^{+}\right.$, 72\%), $795\left([\mathrm{M}+\mathrm{H}]^{+}, 100 \%\right)$; HRMS $\left(\mathrm{ESI}^{+}\right) \mathrm{C}_{49} \mathrm{H}_{71} \mathrm{~N}_{2} \mathrm{O}_{5} \mathrm{Si}^{+}\left([\mathrm{M}+\mathrm{H}]^{+}\right)$requires 795.5127; found 795.5128.

tert-Butyl (3S,4R, $\alpha R)-3-[N$-benzyl- $N$-( $\alpha$-methylbenzyl)amino]-4-( $N, N$-dibenzylamino)-5triisopropylsilyloxy)pentanoate (3S,4R,aR)-47. Doubly Diastereoselective “Matched” Reaction. BuLi (2.2 $\mathrm{M}$ in hexanes, $0.34 \mathrm{~mL}, 0.75 \mathrm{mmol})$ was added dropwise to a stirred solution of $(R)$ - $N$-benzyl- $N-(\alpha$ methylbenzyl)amine (161 mg, $0.764 \mathrm{mmol}$, >99\% ee) in THF (3 mL) at $-78{ }^{\circ} \mathrm{C}$ and the resultant solution was stirred at $-78{ }^{\circ} \mathrm{C}$ for $30 \mathrm{~min}$. A solution of $(R)-44(200 \mathrm{mg}, 0.382 \mathrm{mmol},>99: 1 \mathrm{dr}[(E):(Z)$ ratio]) in THF (1.5 mL) at $-78{ }^{\circ} \mathrm{C}$ was added dropwise via cannula and the resultant solution was stirred at $-78{ }^{\circ} \mathrm{C}$ for 2 h. Satd aq $\mathrm{NH}_{4} \mathrm{Cl}(1 \mathrm{~mL})$ was then added and the resultant solution was allowed to warm to rt and then concentrated in vacuo. The residue was suspended in $10 \%$ aq citric acid $(10 \mathrm{~mL})$ and extracted with $\mathrm{CH}_{2} \mathrm{Cl}_{2}$ $(3 \times 25 \mathrm{~mL})$. The combined organics were washed sequentially with satd aq $\mathrm{NaHCO}_{3}(10 \mathrm{~mL})$ and brine $(10$ $\mathrm{mL}$ ), then dried and concentrated in vacuo. Purification via flash column chromatography (eluent $30-40{ }^{\circ} \mathrm{C}$ petroleum ether/EtOAc, 25:1) gave $(3 S, 4 R, \alpha R)-47$ as a colourless oil (267 mg, 96\%, >99:1 dr); $[\alpha]_{\mathrm{D}}^{20}-0.9(c$ 1.0 in $\left.\mathrm{CHCl}_{3}\right)$.

tert-Butyl (3R,4R, $\alpha S)-3-[N$-benzyl- $N$-( $\alpha$-methylbenzyl)amino]-4-( $N, N$-dibenzylamino)-5(triisopropylsilyloxy)pentanoate $(3 R, 4 R, \alpha S)-49$. Method A. Doubly Diastereoselective "Mismatched" Reaction. BuLi (2.2 M in hexanes, $0.34 \mathrm{~mL}, 0.75 \mathrm{mmol}$ ) was added dropwise to a stirred solution of $(S)-N$ benzyl- $N$-( $\alpha$-methylbenzyl)amine (161 mg, $0.764 \mathrm{mmol},>99 \%$ ee) in THF (3 mL) at $-78{ }^{\circ} \mathrm{C}$ and the resultant solution was stirred at $-78{ }^{\circ} \mathrm{C}$ for $30 \mathrm{~min}$. A solution of $(R)-44(200 \mathrm{mg}, 0.382 \mathrm{mmol},>99: 1 \mathrm{dr}$ $\left[(E):(Z)\right.$ ratio]) in THF $(1.5 \mathrm{~mL})$ at $-78{ }^{\circ} \mathrm{C}$ was added dropwise via cannula and the resultant solution was stirred at $-78{ }^{\circ} \mathrm{C}$ for $2 \mathrm{~h}$. Satd aq $\mathrm{NH}_{4} \mathrm{Cl}(1 \mathrm{~mL})$ was then added and the resultant solution was allowed to warm to rt and then concentrated in vacuo. The residue was suspended in $10 \%$ aq citric acid (10 mL) and extracted with $\mathrm{CH}_{2} \mathrm{Cl}_{2}(3 \times 25 \mathrm{~mL})$. The combined organics were washed sequentially with satd aq $\mathrm{NaHCO}_{3}$ $(10 \mathrm{~mL})$ and brine $(10 \mathrm{~mL})$, then dried and concentrated in vacuo to give an 87:13 mixture of (3R,4R, $\alpha S)-49$ and $(3 S, 4 R, \alpha S)-50$, respectively. Purification via flash column chromatography (eluent $30-40{ }^{\circ} \mathrm{C}$ petroleum ether/EtOAc, 25:1) gave an 87:13 mixture of $(3 R, 4 R, \alpha S)-\mathbf{4 9}$ and $(3 S, 4 R, \alpha S)-50$, respectively, as a colourless oil (231 mg, 83\%). Data for (3S,4R, $\alpha S)-50: \delta_{\mathrm{H}}\left(400 \mathrm{MHz}, \mathrm{CDCl}_{3}\right)$ [selected data] $2.57(1 \mathrm{H}, \mathrm{dd}, J 16.1,3.5$, $\left.\mathrm{C}(2) H_{\mathrm{A}}\right), 2.81\left(1 \mathrm{H}, \mathrm{dd}, J 16.1,8.7, \mathrm{C}(2) H_{\mathrm{B}}\right)$.

Method B. From 60. TIPSCl (41 $\mu \mathrm{L}, 0.190 \mathrm{mmol})$, imidazole (23.6 mg, $0.346 \mathrm{mmol})$ and DMAP (2.1 $\mathrm{mg}, 0.017 \mathrm{mmol}$ ) were added sequentially to a stirred solution of 60 (100 mg, $0.173 \mathrm{mmol}$, >99:1 dr) in $\mathrm{CH}_{2} \mathrm{Cl}_{2}(2 \mathrm{~mL})$ at $\mathrm{rt}$, and the resultant solution was stirred at rt for $18 \mathrm{~h}$ then concentrated in vacuo. The 
residue was partitioned between $\mathrm{Et}_{2} \mathrm{O}(5 \mathrm{~mL})$ and $1 \mathrm{M}$ aq $\mathrm{HCl}(2 \mathrm{~mL})$, and the aqueous layer was extracted with $\mathrm{Et}_{2} \mathrm{O}(3 \times 3 \mathrm{~mL})$. The combined organics were washed with satd aq $\mathrm{NaHCO}_{3}(5 \mathrm{~mL})$, then dried and concentrated in vacuo. Purification via flash column chromatography (eluent 30-40 ${ }^{\circ} \mathrm{C} / \mathrm{EtOAc}, 20: 1$ ) gave $(3 R, 4 R, \alpha S)-49$ as a pale yellow viscous oil (24 mg, 19\%, >99:1 dr); $[\alpha]_{\mathrm{D}}^{22}-7.8$ (c 1.0 in $\left.\mathrm{CHCl}_{3}\right) ; v_{\max } 1724$

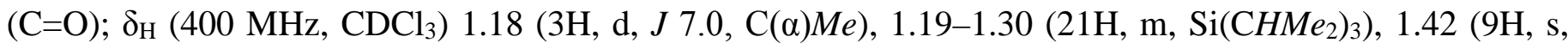
CMe 3 ), 1.78-1.90 (1H, m, C(2)H $\left.H_{\mathrm{A}}\right), 2.71$ (1H, dd, J 17.0, 5.0, C(2)Hв), 2.94-3.03 (1H, m, C(4)H), 3.06-3.21 $\left(1 \mathrm{H}, \mathrm{m}, \mathrm{NCH} \mathrm{A}_{\mathrm{B}} \mathrm{Ph}\right), 3.29\left(1 \mathrm{H}, \mathrm{d}, J\right.$ 15.0, $\left.\mathrm{NCH}_{\mathrm{A}} H_{\mathrm{B}} \mathrm{Ph}\right), 3.36-3.43(1 \mathrm{H}, \mathrm{m}, \mathrm{C}(3) H), 3.67(1 \mathrm{H}, \mathrm{q}, J$ 7.0, $\mathrm{C}(\alpha) H), 3.71-3.79\left(2 \mathrm{H}, \mathrm{m}, \mathrm{N}\left(\mathrm{CH}_{\mathrm{A}} \mathrm{H}_{\mathrm{B}} \mathrm{Ph}\right)_{2}\right), 3.83-3.97$ (3H, m, C(5)H $\left.H_{\mathrm{A}}, \mathrm{N}\left(\mathrm{CH}_{\mathrm{A}} H_{\mathrm{B}} \mathrm{Ph}\right)_{2}\right), 4.50$ (1H, dd, $J$ 10.7, 3.8, C(5)H $\left.H_{\mathrm{B}}\right), 7.12-7.34(20 \mathrm{H}, \mathrm{m}, \mathrm{Ph}) ; \delta_{\mathrm{C}}\left(125 \mathrm{MHz}, \mathrm{CDCl}_{3}\right) 12.0\left(\mathrm{Si}\left(\mathrm{CHMe}_{2}\right)_{3}\right), 18.3\left(\mathrm{Si}(\mathrm{CHMe})_{3}\right), 21.6$

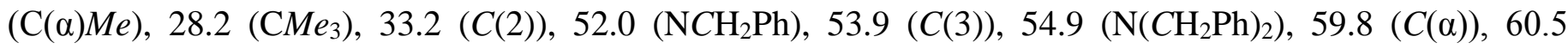
(C(4)), 65.8 (C(5)), 79.9 (CМе $), 126.4,126.5,126.8$ (p-Ph), 127.9, 128.0, 128.2, 128.4, 128.8, 129.8 (o,mPh), 140.4, 140.6, 141.4 (i-Ph), 173.4 (C(1)); m/z (ESI $\left.{ }^{+}\right) 757$ ([M+Na $\left.]^{+}, 18 \%\right), 735$ ([M+H $\left.]^{+}, 100 \%\right)$; HRMS $\left(\mathrm{ESI}^{+}\right) \mathrm{C}_{47} \mathrm{H}_{67} \mathrm{~N}_{2} \mathrm{O}_{3} \mathrm{Si}^{+}\left([\mathrm{M}+\mathrm{H}]^{+}\right)$requires 735.4915; found 735.4917.

tert-Butyl

$(2 R, 3 R, 4 R, \alpha R)-2-h y d r o x y-3-[N$-benzyl- $N$-( $\alpha$-methylbenzyl)amino]-4-( $N, N$ -

dibenzylamino)-5-(triisopropylsilyloxy)pentanoate 51. Doubly Diastereoselective “Matched” Reaction with in situ Enolate Oxidation. BuLi (2.2 M in hexanes, $0.34 \mathrm{~mL}, 0.75 \mathrm{mmol}$ ) was added dropwise to a stirred solution of $(R)-N$-benzyl- $N$-( $\alpha$-methylbenzyl)amine (161 mg, $0.764 \mathrm{mmol}$, >99\% ee) in THF (1 mL) at $-78{ }^{\circ} \mathrm{C}$ and the resultant solution was stirred at $-78{ }^{\circ} \mathrm{C}$ for $30 \mathrm{~min}$. A solution of $(R)-44(200 \mathrm{mg}, 0.382$ mmol, >99:1 dr $\left[(E):(Z)\right.$ ratio]) in THF $(1 \mathrm{~mL})$ at $-78{ }^{\circ} \mathrm{C}$ was added dropwise via cannula and the resultant solution was stirred at $-78{ }^{\circ} \mathrm{C}$ for $2 \mathrm{~h}$. (-)-CSO (175 $\left.\mathrm{mg}, 0.764 \mathrm{mmol}\right)$ was then added and the resultant solution was allowed to warm to rt over $18 \mathrm{~h}$, then concentrated in vacuo. The residue was suspended in $10 \%$ aq citric acid $(10 \mathrm{~mL})$ and extracted with $\mathrm{CH}_{2} \mathrm{Cl}_{2}(3 \times 25 \mathrm{~mL})$. The combined organics were washed sequentially with satd aq $\mathrm{NaHCO}_{3}(10 \mathrm{~mL})$ and brine $(10 \mathrm{~mL})$, then dried and concentrated in vacuo to give a 24:76 mixture of $(3 S, 4 R, \alpha R)-47$ and $(2 R, 3 R, 4 R, \alpha R)-51$, respectively. Purification via flash column chromatography (eluent $30-40{ }^{\circ} \mathrm{C}$ petroleum ether/EtOAc, 20:1; increased to $30-40{ }^{\circ} \mathrm{C}$ petroleum ether/EtOAc, 5:1) gave $(3 S, 4 R, \alpha R)-47$ as a colourless oil (46 mg, 16\%, >99:1 dr); $[\alpha]_{\mathrm{D}}^{20}-0.9$ (c 1.0 in $\left.\mathrm{CHCl}_{3}\right)$. Further elution gave $(2 R, 3 R, 4 R, \alpha R)-51$ as a colourless oil (210 mg, 73\%, >99:1 dr); $\mathrm{C}_{47} \mathrm{H}_{66} \mathrm{~N}_{2} \mathrm{O}_{4} \mathrm{Si}$ requires C, 75.15; H, 8.9; N, 3.7\%; found C, 75.05; H, 8.8; N, 3.8\%; $[\alpha]_{\mathrm{D}}^{20}-13.1$ (c 1.0 in $\left.\mathrm{CHCl}_{3}\right) ; v_{\max } 3021$ $(\mathrm{O}-\mathrm{H}), 1735(\mathrm{C}=\mathrm{O}) ; \delta_{\mathrm{H}}\left(500 \mathrm{MHz}, \mathrm{CDCl}_{3}\right)$ 1.10-1.23 (21H, m, Si(CHMe $\left.)_{3}\right), 1.38(3 \mathrm{H}, \mathrm{d}, J$ 7.7, C( $\left.\alpha) M e\right)$ overlapping 1.40 (9H, s, CMe 3 ), $3.40(1 \mathrm{H}, \mathrm{m}, \mathrm{C}(4) \mathrm{H}), 3.72(1 \mathrm{H}, \mathrm{dd}, \mathrm{J} 4.6,1.7 \mathrm{C}(3) \mathrm{H})$ overlapping $3.75(2 \mathrm{H}$, d, $J$ 14.0, N(CH $\left.\left.\mathrm{A}_{\mathrm{B}} \mathrm{Ph}\right)_{2}\right), 3.80-3.82(1 \mathrm{H}, \mathrm{m}, \mathrm{C}(2) H), 3.87\left(1 \mathrm{H}, \mathrm{d}, J\right.$ 16.4, $\left.\mathrm{NCH}_{\mathrm{A}} \mathrm{H}_{\mathrm{B}} \mathrm{Ph}\right), 3.95$ (1H, q, $J$ 7.7, $\mathrm{C}(\alpha) H), 4.00\left(2 \mathrm{H}, \mathrm{d}, J\right.$ 14.0, $\left.\mathrm{N}\left(\mathrm{CH}_{\mathrm{A}} H_{\mathrm{B}} \mathrm{Ph}\right)_{2}\right)$ overlapping $4.06\left(1 \mathrm{H}, J\right.$ 10.6, 7.1, C(5)H $\left.H_{\mathrm{A}}\right), 4.21(1 \mathrm{H}, J$ 10.6, 
6.3, C(5)HB $), 4.48$ (1H, d, $J$ 16.4, $\left.\mathrm{NCH}_{\mathrm{A}} H_{\mathrm{B}} \mathrm{Ph}\right), 6.37$ (1H, br d, $J$ 6.1, OH), 7.00-7.28 (20H, m, Ph); $\delta_{\mathrm{C}}(125$ MHz, $\left.\mathrm{CDCl}_{3}\right) 12.0$ ( $\left.\mathrm{Si}\left(\mathrm{CHMe}_{2}\right)_{3}\right), 18.2$ (Si(CHMe$\left.)_{3}\right), 20.8$ (C( $\left.\left.\alpha\right) M e\right), 28.1\left(\mathrm{CMe}_{3}\right), 53.5\left(\mathrm{NCH}_{2} \mathrm{Ph}\right), 56.1$ (N(CH $\left.2 \mathrm{Ph})_{2}\right), 57.4(C(3)), 58.5(C(\alpha)), 62.1(C(5)), 64.7(C(4)), 73.7(C(2)), 81.2\left(C \mathrm{Me}_{3}\right), 126.0,126.8$, 127.1, 127.3, 128.0, 128.1, 128.2, 128.6, 129.0 (o,m,p-Ph) 138.7, 141.2, 141.6 (i-Ph), 173.2 (C(1)); m/z

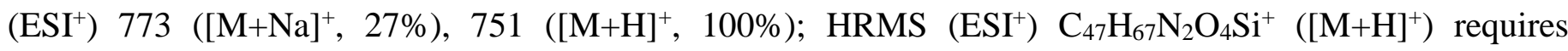
751.4865; found 751.4863.

(2R,3R,4R, $\alpha R)-3-[N$-Benzyl- $N$-( $\alpha$-methylbenzyl)amino]-4-( $N, N$-dibenzylamino)pentan-1,2,5-

triol 52. $\mathrm{LiAlH}_{4}(1.0 \mathrm{M}$ in THF, $2.0 \mathrm{~mL}, 2.0 \mathrm{mmol})$ was added to a stirred solution of 51 (500 mg, 0.666 mmol) in THF (5 mL) at $-78^{\circ} \mathrm{C}$ and the resultant solution was stirred at $\mathrm{rt}$ for $18 \mathrm{~h}$, then cooled to $0{ }^{\circ} \mathrm{C} .2 .0$ $\mathrm{M}$ aq $\mathrm{NaOH}(5 \mathrm{~mL})$ was added and the resultant biphasic mixture was stirred at $\mathrm{rt}$ for $2 \mathrm{~h}$, before being filtered through Celite ${ }^{\circledR}$ (eluent EtOAc) and concentrated in vacuo. Purification via flash column chromatography (eluent $\mathrm{CHCl}_{3} / \mathrm{PrOH}, 20: 1$ ) gave 52 as a pale yellow solid (309 mg, 88\%, >99:1 dr); mp 80-83 ${ }^{\circ} \mathrm{C} ;[\alpha]_{\mathrm{D}}^{22}+29.2\left(\right.$ c 1.0 in $\left.\mathrm{CHCl}_{3}\right) ; v_{\max } 3390(\mathrm{O}-\mathrm{H}) ; \delta_{\mathrm{H}}(500 \mathrm{MHz}, \mathrm{CDCL}) 1.43(3 \mathrm{H}, \mathrm{d}, J$ 7.1.

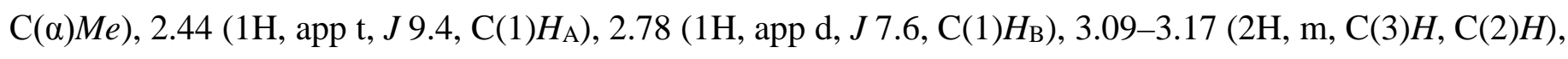
3.22-3.27 (1H, m, C(4)H), $\left.3.60\left(2 \mathrm{H}, \mathrm{d}, J \text { 13.7, N(CH} \mathrm{H}_{\mathrm{B}} \mathrm{Ph}\right)_{2}\right), 3.82(1 \mathrm{H}$, br s, $\mathrm{OH}), 3.91(1 \mathrm{H}, \mathrm{q}, J$ 7.1, $\mathrm{C}(\alpha) H), 4.03\left(1 \mathrm{H}, \mathrm{d}, J\right.$ 16.1, $\left.\mathrm{NCH}_{\mathrm{A}} \mathrm{H}_{\mathrm{B}} \mathrm{Ph}\right), 4.09-4.17$ (3H, m, C(5)H $\left.H_{\mathrm{A}}, \mathrm{N}\left(\mathrm{CH}_{\mathrm{A}} H_{\mathrm{B}} \mathrm{Ph}\right)_{2}\right), 4.32(1 \mathrm{H}, \mathrm{dd}, J 11.2$, 5.0, C(5)HB $), 4.62\left(1 \mathrm{H}, \mathrm{d}, J\right.$ 16.1, $\left.\mathrm{NCH}_{\mathrm{A}} H_{\mathrm{B}} \mathrm{Ph}\right), 7.16-7.39(20 \mathrm{H}, \mathrm{m}, \mathrm{Ph}) ; \delta_{\mathrm{C}}\left(125 \mathrm{MHz}, \mathrm{CDCl}_{3}\right) 19.5$ $(\mathrm{C}(\alpha) M e), 53.4\left(\mathrm{NCH}_{2} \mathrm{Ph}\right), 56.0(C(3)), 56.2\left(\mathrm{~N}\left(\mathrm{CH}_{2} \mathrm{Ph}\right)_{2}\right), 58.2(C(\alpha)), 59.6(C(5)), 60.5(C(4)), 65.0(C(1))$, 72.8 (C(2)), 126.7, 127.4, 127.5, 127.8, 128.2, 128.3, 128.4, 128.5, 129.3 (o,m,p-Ph), 137.8, 139.8, 140.7 (i$\mathrm{Ph}) ; \mathrm{m} / \mathrm{z}\left(\mathrm{ESI}^{+}\right) 525\left([\mathrm{M}+\mathrm{H}]^{+}, 100 \%\right) ; \mathrm{HRMS}\left(\mathrm{ESI}^{+}\right) \mathrm{C}_{34} \mathrm{H}_{41} \mathrm{~N}_{2} \mathrm{O}_{3}{ }^{+}\left([\mathrm{M}+\mathrm{H}]^{+}\right)$requires 525.3112; found 525.3107.

tert-Butyl

$(2 R, 3 R, 4 R, \alpha R)-2-h y d r o x y-3-[N$-benzyl- $N$-( $\alpha$-methylbenzyl)amino]-4-( $N, N$ -

dibenzylamino)-5-(triisopropylsilyloxy)pentanoate 51 and tert-butyl $(2 S, 3 S, 4 S, \alpha S)-3-\left[N-3^{\prime}, 4^{\prime}-\right.$ dimethoxybenzyl- $N$-( $\alpha$-methylbenzyl)amino]-4-( $N, N$-dibenzylamino)-5-

(triisopropylsilyloxy)pentanoate 53. Parallel Kinetic Resolution with in situ Enolate Oxidation. BuLi (2.2

$\mathrm{M}$ in hexanes, $0.34 \mathrm{~mL}, 0.75 \mathrm{mmol})$ was added dropwise to a stirred solution of $(R)-N$-benzyl- $N$ - $(\alpha-$ methylbenzyl)amine (80.7 mg, $0.382 \mathrm{mmol},>99 \%$ ee) and (S)- $N$-3,4-dimethoxybenzyl- $N$ - $(\alpha-$ methylbenzyl)amine (104 mg, $0.382 \mathrm{mmol}$, >99\% ee) in THF (1 mL) at $-78{ }^{\circ} \mathrm{C}$ and the resultant solution was stirred at $-78{ }^{\circ} \mathrm{C}$ for $30 \mathrm{~min}$. A solution of $(R S)-44(200 \mathrm{mg}, 0.382 \mathrm{mmol},>99: 1 \mathrm{dr}[(E):(Z)$ ratio]) in THF ( $1 \mathrm{~mL})$ at $-78{ }^{\circ} \mathrm{C}$ was added dropwise via cannula and the resultant solution was stirred at $-78{ }^{\circ} \mathrm{C}$ for 2 h. (-)-CSO (87 mg, $0.38 \mathrm{mmol})$ and (+)-CSO (87 mg, $0.38 \mathrm{mmol})$ were then added and the resultant solution was allowed to warm to rt over $18 \mathrm{~h}$, then concentrated in vacuo. The residue was suspended in $10 \%$ aq 
citric acid $(10 \mathrm{~mL})$ and extracted with $\mathrm{CH}_{2} \mathrm{Cl}_{2}(3 \times 25 \mathrm{~mL})$. The combined organics were washed sequentially with satd aq $\mathrm{NaHCO}_{3}(10 \mathrm{~mL})$ and brine $(10 \mathrm{~mL})$, then dried and concentrated in vacuo. Purification via flash column chromatography (eluent 30-40 ${ }^{\circ} \mathrm{C}$ petroleum ether/EtOAc, 25:1; increased to $30-40{ }^{\circ} \mathrm{C}$ petroleum ether/EtOAc, 5:1) gave $(3 S, 4 R, \alpha R)-47$ as a colourless oil (42 mg, 15\%, $\left.>99: 1 \mathrm{dr}\right) ;[\alpha]_{\mathrm{D}}^{25}$ -0.7 (c 1.0 in $\left.\mathrm{CHCl}_{3}\right)$. Further elution gave $(2 R, 3 R, 4 R, \alpha R)-51$ as a yellow oil (34 mg, 12\%, $\left.>99: 1 \mathrm{dr}\right) ;[\alpha]_{\mathrm{D}}^{25}$ -13.6 (c 1.0 in $\mathrm{CHCl}_{3}$ ). Further elution gave (3R,4S, $\left.\alpha S\right)-\mathbf{4 8}$ as a colourless oil (42 mg, 14\%, $\left.>99: 1 \mathrm{dr}\right)$; $[\alpha]_{\mathrm{D}}^{25}$ +3.4 (c 1.0 in $\left.\mathrm{CHCl}_{3}\right)$. Further elution gave (2S,3S,4S, $\left.\alpha S\right)$-53 as a colourless oil (12 mg, 4\%, >99:1 dr); $[\alpha]_{\mathrm{D}}^{25}$ +24.9 (c 1.0 in $\left.\mathrm{CHCl}_{3}\right)$; v $v_{\max } 3514(\mathrm{O}-\mathrm{H}), 1722(\mathrm{C}=\mathrm{O})$; $\delta_{\mathrm{H}}\left(500 \mathrm{MHz}, \mathrm{CDCl}_{3}\right)$ 1.15-1.22 (21H, m,

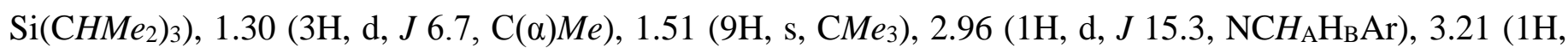
br s, OH), 3.59-3.64 (1H, m, C(4)H), 3.76 (3H, s, OMe), 3.79 (3H, s, OMe), 3.89-3.91 (3H, m, $\mathrm{NCH}_{\mathrm{A}} \mathrm{H}_{\mathrm{B}} \mathrm{Ar}$, $\left.\mathrm{N}\left(\mathrm{CH}_{\mathrm{A}} \mathrm{H}_{\mathrm{B}} \mathrm{Ph}\right)_{2}\right), 3.99(1 \mathrm{H}, \mathrm{dd}, J$ 6.4, 3.3, C(3)H), $4.05(1 \mathrm{H}, \mathrm{q}, J$ 6.7, $\mathrm{C}(\alpha) H), 4.11(2 \mathrm{H}, \mathrm{d}, J$ 14.0, $\left.\mathrm{N}\left(\mathrm{CH}_{\mathrm{A}} H_{\mathrm{B}} \mathrm{Ph}\right)_{2}\right), 4.20\left(1 \mathrm{H}, \mathrm{dd}, J 11.4,6.2, \mathrm{C}(5) H_{\mathrm{A}}\right), 4.38\left(1 \mathrm{H}, \mathrm{dd}, J 11.4,3.1, \mathrm{C}(5) H_{\mathrm{B}}\right), 4.40-4.42(1 \mathrm{H}, \mathrm{m}$, C(2)H), 6.11 (1H, dd, J 8.3, 1.7, C(6')H), 6.42-6.48 (2H, m, C(2')H, C(5')H), 6.92-6.98 (5H, m, Ph), 7.277.31 (2H, m, Ph), 7.37 (4H, t, J 7.6, Ph), 7.48 (4H, d, J 7.4, Ph); $\delta_{\mathrm{C}}\left(125 \mathrm{MHz}, \mathrm{CDCl}_{3}\right) 12.2\left(\mathrm{Si}\left(\mathrm{CHMe}_{2}\right)_{3}\right)$, $18.3\left(\mathrm{Si}(\mathrm{CHMe})_{3}\right), 22.0(\mathrm{C}(\alpha) M e), 28.1\left(\mathrm{CMe}_{3}\right), 53.9\left(\mathrm{NCH}_{2} \mathrm{Ar}\right), 55.6\left(\mathrm{~N}\left(\mathrm{CH}_{2} \mathrm{Ph}\right)_{2}\right)$, 55.7, $55.9(\mathrm{OMe}), 59.0$ (C(4)), 59.4 (C(3)), $61.5(C(5)), 62.7(C(\alpha)), 74.1(C(2)), 82.3\left(C \mathrm{Me}_{3}\right), 110.3\left(C\left(5^{\prime}\right)\right), 111.4\left(C\left(2^{\prime}\right)\right), 119.6$ (C(6')), 126.4, 127.0, 127.3, 128.3, 128.4, 129.7 (o,m,p-Ph), 135.3 (C(1')), 140.0, 145.1 (i-Ph), 146.6 (C(4')), $148.1\left(C\left(3^{\prime}\right)\right), 174.1(C(1)) ; \mathrm{m} / \mathrm{z}\left(\mathrm{ESI}^{+}\right) 812\left([\mathrm{M}+\mathrm{H}]^{+}, 100 \%\right), 755$ (17\%); HRMS (ESI $\left.{ }^{+}\right) \mathrm{C}_{49} \mathrm{H}_{71} \mathrm{~N}_{2} \mathrm{O}_{6} \mathrm{Si}^{+}$ $\left([\mathrm{M}+\mathrm{H}]^{+}\right)$requires 811.5076; found 811.5067.

tert-Butyl

hydroxypentanoate
$(3 S, 4 R, \alpha R)-3-[N$-benzyl- $N$-( $\alpha$-methylbenzyl)amino]-4-( $N, N$-dibenzylamino)-554 and $(3 S, 4 R, \alpha R)-3-[N$-benzyl- $N$-( $\alpha$-methylbenzyl)amino]-4-( $N, N-$

dibenzylamino)-5-pentanolactone 55. Method A. TBAF (1.0 M in THF, $0.41 \mathrm{~mL}, 0.41 \mathrm{mmol}$ ) was added to a stirred solution of $(3 S, 4 R, \alpha R)-47(200 \mathrm{mg}, 0.272 \mathrm{mmol},>99: 1 \mathrm{dr})$ in THF $(2 \mathrm{~mL})$ at $0{ }^{\circ} \mathrm{C}$ and the resultant solution was stirred at $0{ }^{\circ} \mathrm{C}$ for $2 \mathrm{~h}$. $\mathrm{Et}_{2} \mathrm{O}(1 \mathrm{~mL})$ and $\mathrm{H}_{2} \mathrm{O}(1 \mathrm{~mL})$ were added and the aqueous layer was extracted with $\mathrm{Et}_{2} \mathrm{O}(3 \times 25 \mathrm{~mL})$. The combined organics were washed with satd aq $\mathrm{NaHCO}_{3}(25 \mathrm{~mL})$, then dried and concentrated in vacuo to give 82\% conversion to a 16:84 mixture of $\mathbf{5 4}$ and $\mathbf{5 5}$, respectively. Purification via flash column chromatography (eluent 30-40 ${ }^{\circ} \mathrm{C}$ petroleum ether/EtOAc, 20:1; increased to $30-40{ }^{\circ} \mathrm{C}$ petroleum ether/EtOAc, 5:1) gave $(3 S, 4 R, \alpha R)-47$ as a colourless oil (18 mg, 9\%, >99:1 dr); $[\alpha]_{\mathrm{D}}^{20}$ -1.4 (c 1.0 in $\mathrm{CHCl}_{3}$ ). Further elution gave 54 as a colourless oil (20 mg, 13\% >99:1 dr); $[\alpha]_{\mathrm{D}}^{20}-26.7$ (c 1.0 in $\left.\mathrm{CHCl}_{3}\right) ; v_{\max } 3427(\mathrm{O}-\mathrm{H}), 1721(\mathrm{C}=\mathrm{O}) ; \delta_{\mathrm{H}}\left(500 \mathrm{MHz}, \mathrm{CDCl}_{3}\right) 1.38\left(9 \mathrm{H}, \mathrm{s}, \mathrm{CMe}_{3}\right), 1.63(3 \mathrm{H}, \mathrm{d}, J$ 6.9, $\mathrm{C}(\alpha) M e), 1.86\left(1 \mathrm{H}, \mathrm{dd}, J\right.$ 16.7, 2.4, C(2)H $\left.H_{\mathrm{A}}\right), 1.94\left(1 \mathrm{H}, \mathrm{dd}, J 16.7,8.8, \mathrm{C}(2) H_{\mathrm{B}}\right), 3.07(1 \mathrm{H}, \mathrm{m}, \mathrm{C}(4) H), 3.22$ (1H, br s, OH), 3.44 (1H, dd, $J$ 10.9, 8.7, C(5)H $\left.H_{\mathrm{A}}\right), 3.55\left(1 \mathrm{H}, \mathrm{d}, J\right.$ 15.0, $\left.\mathrm{NCH}_{\mathrm{A}} \mathrm{H}_{\mathrm{B}} \mathrm{Ph}\right)$ overlapping 3.54-3.59 
(1H, m, C(5)HB $\left.), 3.69\left(2 \mathrm{H}, \mathrm{d}, J \text { 13.9, N( } \mathrm{CH}_{\mathrm{A}} \mathrm{H}_{\mathrm{B}} \mathrm{Ph}\right)_{2}\right), 3.78\left(2 \mathrm{H}, \mathrm{d}, J 13.9, \mathrm{~N}\left(\mathrm{CH}_{\mathrm{A}} H_{\mathrm{B}} \mathrm{Ph}\right)_{2}\right), 3.90(1 \mathrm{H}, \mathrm{m}$, C(3)H), $4.04(1 \mathrm{H}, \mathrm{q}, J$ 6.9, C( $\alpha) H)$ overlapping 4.04 (1H, d, $J$ 15.0, $\left.\mathrm{NCH}_{\mathrm{A}} H_{\mathrm{B}} \mathrm{Ph}\right), 7.16-7.40(20 \mathrm{H}, \mathrm{m}, P h) ; \delta_{\mathrm{C}}$

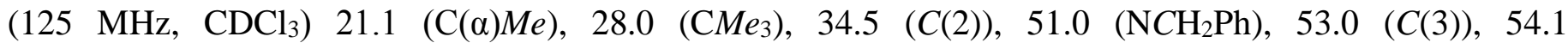

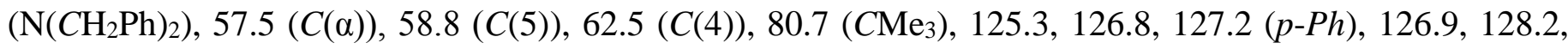
128.3, 128.7, 128.9, 129.0 (o,m-Ph), 139.9, 140.1, 142.5 (i-Ph), 172.2 (C(1)); m/z (ESI $\left.{ }^{+}\right) 579\left([\mathrm{M}+\mathrm{H}]^{+}\right.$, 100\%); HRMS $\left(\mathrm{ESI}^{+}\right) \mathrm{C}_{38} \mathrm{H}_{47} \mathrm{~N}_{2} \mathrm{O}_{3}{ }^{+}\left([\mathrm{M}+\mathrm{H}]^{+}\right)$requires 579.3581; found 579.3584. Further elution gave 55 as a white foam (94 mg, 69\%, >99:1 dr); $[\alpha]_{\mathrm{D}}^{20}-60.7$ (c 1.0 in $\left.\mathrm{CHCl}_{3}\right) ; v_{\max } 1748(\mathrm{C}=\mathrm{O}) ; \delta_{\mathrm{H}}\left(500 \mathrm{MHz}, \mathrm{CDCl}_{3}\right)$ 1.37 (3H, d, J 6.9, C( $\alpha) M e), 2.15$ (1H, dd, $J$ 15.1, 6.5, C(2)H $\left.H_{\mathrm{A}}\right), 2.23\left(1 \mathrm{H}, \mathrm{dd}, J 15.1,9.0, \mathrm{C}(2) H_{\mathrm{B}}\right), 3.27(1 \mathrm{H}$, m, C(4)H), 3.47 (2H, d, $J$ 13.9, N( $\left.\left.\mathrm{CH}_{\mathrm{A}} \mathrm{H}_{\mathrm{B}} \mathrm{Ph}\right)_{2}\right), 3.56\left(1 \mathrm{H}, \mathrm{d}, J 14.3, \mathrm{NCH}_{\mathrm{A}} \mathrm{H}_{\mathrm{B}} \mathrm{Ph}\right), 3.59-3.65(1 \mathrm{H}, \mathrm{m}, \mathrm{C}(3) H)$ overlapping $3.62\left(1 \mathrm{H}, \mathrm{d}, J\right.$ 14.3, $\left.\mathrm{NCH}_{\mathrm{A}} \mathrm{H}_{\mathrm{B}} \mathrm{Ph}\right), 3.82(1 \mathrm{H}, \mathrm{q}, J$ 6.9, $\mathrm{C}(\alpha) H)$ overlapping $3.84(2 \mathrm{H}, \mathrm{d}, J$ 13.9, $\left.\mathrm{N}\left(\mathrm{CH}_{\mathrm{A}} H_{\mathrm{B}} \mathrm{Ph}\right)_{2}\right), 4.15$ (1H, dd, $J$ 12.3, 4.4, C(5)H $\left.H_{\mathrm{A}}\right), 4.43$ (1H, dd, $J$ 12.3, 4.7, C(5)H $\left.H_{\mathrm{B}}\right), 7.00-7.46$ (20H, m, $\left.P h) ; \delta_{\mathrm{C}}\left(125 \mathrm{MHz}, \mathrm{CDCl}_{3}\right) 20.4(\mathrm{C}(\alpha) M e), 31.8(C(2)), 50.9\left(\mathrm{NCH}_{2} \mathrm{Ph}\right), 53.8(C(3)), 54.9\left(\mathrm{~N}_{(} \mathrm{CH}_{2} \mathrm{Ph}\right)_{2}\right), 57.9$ $(C(4))$, $58.1(C(\alpha)), 65.5(C(5)), 126.8,127.3,127.5,127.6,128.2,128.4,128.4,128.6,129.0(o, m, p-P h)$, 139.1, 140.2, 142.7 (i-Ph), $172.9(C(1)) ; \mathrm{m} / \mathrm{z}\left(\mathrm{ESI}^{+}\right) 527\left([\mathrm{M}+\mathrm{Na}]^{+}, 20 \%\right), 505\left([\mathrm{M}+\mathrm{H}]^{+}, 100 \%\right)$; HRMS $\left(\mathrm{ESI}^{+}\right) \mathrm{C}_{34} \mathrm{H}_{36} \mathrm{~N}_{2} \mathrm{NaO}_{2}{ }^{+}\left([\mathrm{M}+\mathrm{Na}]^{+}\right)$requires 527.2669; found 527.2663.

Method B. TBAF (1.0 M in THF, $3.24 \mathrm{~mL}, 3.24 \mathrm{mmol})$ was added to a stirred solution of $(3 S, 4 R, \alpha R)$ 47 (1.59 g, $2.16 \mathrm{mmol},>99: 1 \mathrm{dr})$ in THF $(15 \mathrm{~mL})$ at $0{ }^{\circ} \mathrm{C}$ and the resultant solution was stirred at rt for $24 \mathrm{~h}$. $\mathrm{Et}_{2} \mathrm{O}(15 \mathrm{~mL})$ and $\mathrm{H}_{2} \mathrm{O}(15 \mathrm{~mL})$ were added and the aqueous layer was extracted with $\mathrm{Et}_{2} \mathrm{O}(3 \times 50 \mathrm{~mL})$. The combined organics were washed with satd aq $\mathrm{NaHCO}_{3}(100 \mathrm{~mL})$, then dried and concentrated in vacuo to give 55. Purification via flash column chromatography (eluent $30-40{ }^{\circ} \mathrm{C}$ petroleum ether/EtOAc, 5:1) gave 55 as a pale yellow oil $(1.07 \mathrm{~g}, 98 \%,>99: 1 \mathrm{dr}) ;[\alpha]_{\mathrm{D}}^{20}-55.1\left(\right.$ c 1.0 in $\left.\mathrm{CHCl}_{3}\right)$.

\section{$(2 R, 3 S, \alpha R, E)-2-(N, N$-Dibenzylamino)-3-[ $N$-benzyl- $N$-( $\alpha$-methylbenzyl)amino]octadec-5-en-1-ol}

57 and $(2 R, 3 S, \alpha R, Z)-2-(N, N$-dibenzylamino)-3-[ $N$-benzyl- $N$-( $\alpha$-methylbenzyl)amino]octadec-5-en-1-ol

58. DIBAL-H (1.0 M in PhMe, $2.82 \mathrm{~mL}, 2.82 \mathrm{mmol})$ was added to a stirred solution of 55 (1.36 g, 2.69 mmol, >99:1 dr) in PhMe $(13 \mathrm{~mL})$ at $-78{ }^{\circ} \mathrm{C}$ and the resultant mixture was stirred at $-78{ }^{\circ} \mathrm{C}$ for $1 \mathrm{~h}$. Meanwhile, BuLi (2.2 M in hexanes, $1.78 \mathrm{~mL}, 3.91 \mathrm{mmol}$ ) was added dropwise to a stirred solution of $\left[\mathrm{C}_{13} \mathrm{H}_{27} \mathrm{PPh}_{3}\right]^{+}[\mathrm{Br}]^{-}(2.12 \mathrm{~g}, 4.03 \mathrm{mmol})$ in THF $(6.5 \mathrm{~mL})$ at $0{ }^{\circ} \mathrm{C}$ and the resultant solution was stirred at 0 ${ }^{\circ} \mathrm{C}$ for $30 \mathrm{~min}$. The 'lactol' solution was then added dropwise via cannula and the resultant solution was stirred at $80^{\circ} \mathrm{C}$ for $1 \mathrm{~h}$. The resultant solution was allowed to cool to rt, then $\mathrm{H}_{2} \mathrm{O}(5 \mathrm{~mL})$ and brine $(5 \mathrm{~mL})$ were added sequentially and the aqueous layer was extracted with EtOAc $(3 \times 10 \mathrm{~mL})$. The combined organics were washed with satd aq $\mathrm{NaHCO}_{3}(30 \mathrm{~mL})$, then dried and concentrated in vacuo. Purification via flash column chromatography (eluent $30-40{ }^{\circ} \mathrm{C}$ petroleum ether/EtOAc, 12:1) gave an 50:50 mixture of 57 
and 58 as a colourless viscous oil (1.32 g, 73\%); $v_{\max } 3457(\mathrm{O}-\mathrm{H}) ; \delta_{\mathrm{H}}\left(400 \mathrm{MHz}, \mathrm{CDCl}_{3}\right)$ 0.88-0.97 (6H, m, $\left.\mathrm{C}(18) H_{3}\right), 1.20-1.35\left(40 \mathrm{H}, \mathrm{m}, \mathrm{C}(8) H_{2}-\mathrm{C}(17) H_{2}\right), 1.44(3 \mathrm{H}, \mathrm{d}, J$ 7.3, C( $\left.\alpha) M e\right), 1.48(3 \mathrm{H}, \mathrm{d}, J$ 6.9, C( $(\alpha) M e)$, 1.84-1.94 (4H, m, C(7)H $\left.H_{2}\right), 1.97-2.06$ (4H, m, C(4)H $\left.H_{2}\right), 3.09$ (2H, br s, OH), 3.15-3.28 (4H, m, C(2)H, $\mathrm{C}(3) H)$, 3.46-3.73 (14H, m, C(1) $\left.H_{2}, \mathrm{NCH}_{\mathrm{A}} \mathrm{H}_{\mathrm{B}} \mathrm{Ph}, \mathrm{N}\left(\mathrm{CH}_{2} \mathrm{Ph}\right)_{2}\right)$, 3.98-4.15 (4H, m, C( $\left.\left.\alpha\right) H, \mathrm{NCH}_{\mathrm{A}} H_{\mathrm{B}} \mathrm{Ph}\right)$, 5.01-5.18 (2H, m, C(5)H), 5.20-5.34 (2H, m, C(6)H), 7.14-7.40 (40H, m, Ph); $\delta_{\mathrm{C}}\left(100 \mathrm{MHz}, \mathrm{CDCl}_{3}\right) 14.2$ (C(18)), 21.0, $21.4(\mathrm{C}(\alpha) M e), 22.7(C(17)), 25.6(C(4)$ [58]), $27.8(C(7)$ [58]), 29.3, 29.4, 29.7, $29.7(C(8)-$ $C(16)), 30.5$ (C(4) [57]), 31.9 (C(8)-C(16)), 32.7 (C(7) [57]), 51.2, 51.3, 53.7, 54.2, 57.6, 58.4, 59.5, 59.8, $63.3\left(C(1)-C(3), C(\alpha), \mathrm{NCH}_{2} \mathrm{Ph}, \mathrm{N}\left(\mathrm{CH}_{2} \mathrm{Ph}\right)_{2}\right), 126.6,126.7,127.0,127.0,127.1,128.2,128.2,128.3,128.3$, 128.3, 128.4, 128.4, 128.7 (o,m,p-Ph), 128.8, 128.9 (C(5)), 128.9, 129.0 (o,m,p-Ph), 130.6, 132.1 (C(6)), 139.9, 140.0, 141.1, 141.1, 144.1, 144.4 (i-Ph); m/z (ESI $) 673.5\left([\mathrm{M}+\mathrm{H}]^{+}, 72 \%\right) ; \mathrm{HRMS}^{+}\left(\mathrm{ESI}^{+}\right) \mathrm{C}_{47} \mathrm{H}_{65} \mathrm{~N}_{2} \mathrm{O}^{+}$ $\left([\mathrm{M}+\mathrm{H}]^{+}\right)$requires 673.5091; found 673.5083.

(2R,3S)-2,3-Diacetamidooctadecan-1-yl acetate 59. Step 1. $\mathrm{Pd}(\mathrm{OH})_{2} / \mathrm{C}(50 \% \mathrm{w} / \mathrm{w}$ of substrate, 100 mg) was added to a vigorously stirred solution of a 50:50 mixture of 57 and 58 (200 mg, $0.297 \mathrm{mmol}$ ) in degassed $\mathrm{HCl}(1.25 \mathrm{M}$ in $\mathrm{MeOH}, 3 \mathrm{~mL})$ at $\mathrm{rt}$ and the resultant suspension was stirred under $\mathrm{H}_{2}(5 \mathrm{~atm})$ at $\mathrm{rt}$ for $72 \mathrm{~h}$, then filtered through Celite ${ }^{\circledR}$ (eluent $\mathrm{MeOH}$ ) and concentrated in vacuo.

Step 2. $\mathrm{Ac}_{2} \mathrm{O}(225 \mu \mathrm{L}, 2.38 \mathrm{mmol})$ and DMAP (3.6 mg, $\left.0.030 \mathrm{mmol}\right)$ were added sequentially to a stirred solution of the residue from the previous step in pyridine (838 $\mu \mathrm{L}, 10.4 \mathrm{mmol}$ ) at rt, and the resultant solution was stirred at rt for $72 \mathrm{~h}$. EtOAc $(5 \mathrm{~mL})$ was added, the resultant solution was washed with satd aq $\mathrm{CuSO}_{4}(5 \mathrm{~mL})$, and the aqueous layer was extracted with EtOAc $(3 \times 5 \mathrm{~mL})$. The combined organics were washed with satd aq $\mathrm{NaHCO}_{3}(3 \times 10 \mathrm{~mL})$ and the combined aqueous layers were then extracted with EtOAc $(3 \times 10 \mathrm{~mL})$. The combined organics were dried and concentrated in vacuo. Recrystallisation $\left(\mathrm{CH}_{2} \mathrm{Cl}_{2} / 30-40{ }^{\circ} \mathrm{C}\right.$ petroleum ether) gave 59 as a pale orange solid (101 mg, 79\%, >99:1 dr); mp 115-116 ${ }^{\circ} \mathrm{C} ;[\alpha]_{\mathrm{D}}^{22}-16.0$ (c 1.0 in $\mathrm{CHCl}_{3}$ ); $v_{\max } 3282(\mathrm{~N}-\mathrm{H}), 1737$ (C=O ester), 1645 (C=O amide); $\delta_{\mathrm{H}}(500 \mathrm{MHz}$, $\left.\mathrm{CDCl}_{3}\right) 0.88\left(3 \mathrm{H}, \mathrm{t}, J\right.$ 7.0, C(18)H $\left.H_{3}\right), 1.20-1.33\left(26 \mathrm{H}, \mathrm{m}, \mathrm{C}(5) \mathrm{H}_{2}-\mathrm{C}(17) \mathrm{H}_{2}\right), 1.36-1.45\left(1 \mathrm{H}, \mathrm{m}, \mathrm{C}(4) \mathrm{H}_{\mathrm{A}}\right)$, 1.56-1.64 (1H, m, C(4)Hв), 1.97 (3H, s, COMe), 1.98 (3H, s, COMe), 2.10 (3H, s, COMe), 3.97 (1H, ddd, J 18.0, 9.0, 3.6, C(3)H), 4.05-4.11 (1H, m, C(2)H), 4.14 (1H, dd, $\left.J 11.7,3.6, \mathrm{C}(1) H_{\mathrm{A}}\right), 4.20$ (1H, dd, $J 11.7$, 5.0, C(1)HB ), 5.91 (1H, d, J 9.1, NHAc), 6.46 (1H, d, J 8.5, NHAc); $\delta_{\mathrm{C}}\left(125 \mathrm{MHz}, \mathrm{CDCl}_{3}\right) 14.1$ (C(18)), 20.8 (COMe), 22.7 (C(17)), 23.2, 23.2 (COMe), 29.3, 29.4, 29.5, 29.5, 29.6, 29.6, 29.6, 29.7 (C(5)-C(16)), 31.5 (C(4)), 31.9 (C(5)-C(16)), $50.4(C(3)), 52.6(C(2)), 63.7(C(1)), 170.9,171.0,171.2(C O M e) ; \mathrm{m} / \mathrm{z}$

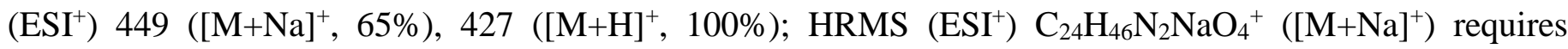
449.3350; found 449.3338. 
hydroxypentanoate 60. TBAF (1.0 M in THF, $1.02 \mathrm{~mL}, 1.02 \mathrm{mmol}$ ) was added to a stirred solution of an 87:13 mixture of 49 and 50 (500 mg, $0.680 \mathrm{mmol})$ in THF $(12 \mathrm{~mL})$ at $0{ }^{\circ} \mathrm{C}$ and the resultant solution was stirred at rt for $24 \mathrm{~h}$. $\mathrm{Et}_{2} \mathrm{O}(5 \mathrm{~mL})$ and $\mathrm{H}_{2} \mathrm{O}(5 \mathrm{~mL})$ were added and the aqueous layer was extracted with $\mathrm{Et}_{2} \mathrm{O}(3 \times 10 \mathrm{~mL})$. The combined organics were washed with satd aq $\mathrm{NaHCO}_{3}(30 \mathrm{~mL})$, then dried and concentrated in vacuo. Purification via flash column chromatography (eluent $30-40{ }^{\circ} \mathrm{C}$ petroleum ether/EtOAc, 5:1) gave 60 as a pale yellow oil (260 mg, 66\%, >99:1 dr); $[\alpha]_{\mathrm{D}}^{22}-26.4$ (c 1.0 in $\mathrm{CHCl}_{3}$ ); $v_{\max }$ $3424(\mathrm{O}-\mathrm{H}), 1724(\mathrm{C}=\mathrm{O})$; $\delta_{\mathrm{H}}\left(500 \mathrm{MHz}, \mathrm{MeOH}-d_{4}\right) 1.16$ (3H, d, J 6.8, C( $\left.\left.\alpha\right) M e\right), 1.41$ (9H, s, CMe $), 1.94-$ $2.03\left(1 \mathrm{H}, \mathrm{m}, \mathrm{C}(2) H_{\mathrm{A}}\right), 2.74\left(1 \mathrm{H}, \mathrm{dd}, J\right.$ 16.5, 3.0, C(2)H $\left.H_{\mathrm{B}}\right), 2.86-2.93(1 \mathrm{H}, \mathrm{m}, \mathrm{C}(4) H), 3.26-3.31(2 \mathrm{H}, \mathrm{m}$, $\mathrm{NCH}_{2} \mathrm{Ph}$ ), 3.54 (2H, d, $J$ 11.7, N(CH $\left.\left.\mathrm{CH}_{\mathrm{B}} \mathrm{Ph}\right)_{2}\right), 3.62-3.72$ (3H, m, C(3)H, $\left.\mathrm{N}\left(\mathrm{CH}_{\mathrm{A}} H_{\mathrm{B}} \mathrm{Ph}\right)_{2}\right), 3.73(1 \mathrm{H}, \mathrm{q}, J 6.8$, $\mathrm{C}(\alpha) H)$, 3.80-3.87 (1H, m, C(5)H $\left.H_{\mathrm{A}}\right), 3.90-4.05$ (1H, m, C(5)HB ), 7.15-7.30 (20H, m, Ph); $\delta_{\mathrm{C}}(125 \mathrm{MHz}$, MeOH-d $\left.)_{4} 22.4(\mathrm{C}(\alpha) M e), 28.7(\mathrm{CMe})_{3}\right), 34.3(C(2)), 53.7\left(\mathrm{NCH}_{2} \mathrm{Ph}\right), 55.6\left(\mathrm{~N}\left(\mathrm{CH}_{2} \mathrm{Ph}\right)_{2}\right), 56.6(C(3)), 61.3$ (C(5)), $61.5(C(4)), 63.1(C(\alpha)), 81.7\left(C \mathrm{Me}_{3}\right), 128.0,128.1,128.4,129.2,129.3,129.6,130.0,130.0,130.8$ (o,m,p-Ph), 141.5, 142.0, 145.5 (i-Ph), 175.2 (C(1)); m/z (ESI $\left.\left.{ }^{+}\right) 579\left([\mathrm{M}+\mathrm{H}]^{+}, 100 \%\right) ; \mathrm{HRMS}_{(\mathrm{ESI}}^{+}\right)$ $\mathrm{C}_{38} \mathrm{H}_{47} \mathrm{~N}_{2} \mathrm{O}_{3}{ }^{+}\left([\mathrm{M}+\mathrm{H}]^{+}\right)$requires 579.3581; found 579.3572. Further elution gave an impure sample of $\mathbf{6 1}$ as a colourless oil (37 mg, 10\%); $v_{\max } 1748(\mathrm{C}=\mathrm{O}) ; \delta_{\mathrm{H}}\left(400 \mathrm{MHz}, \mathrm{CDCl}_{3}\right) 1.38(3 \mathrm{H}, \mathrm{d}, \mathrm{J}$ 6.9, C( $\left.\alpha) M e\right), 2.72$ (1H, dd, $J$ 15.3, 6.6, C(2)H $\left.H_{\mathrm{A}}\right), 2.82$ (1H, dd, $J$ 15.3, 8.5, C(2)Hв), 3.25 (1H, app q, J 4.9, C(4)H), 3.28 (2H, d, $J$ 13.7, $\left.\mathrm{N}\left(\mathrm{CH}_{\mathrm{A}} \mathrm{H}_{\mathrm{B}} \mathrm{Ph}\right)_{2}\right), 3.50$ (2H, d, $J$ 13.7, N( $\left.\left.\mathrm{CH}_{\mathrm{A}} H_{\mathrm{B}} \mathrm{Ph}\right)_{2}\right)$, 3.53-3.56 (1H, m, C(3)H), 3.59 (1H, d, $J$ 13.6, $\left.\mathrm{NCH}_{\mathrm{A}} \mathrm{H}_{\mathrm{B}} \mathrm{Ph}\right), 3.65$ (1H, d, $J$ 13.6, $\left.\mathrm{NCH}_{\mathrm{A}} H_{\mathrm{B}} \mathrm{Ph}\right), 3.90(1 \mathrm{H}, \mathrm{q}, J$ 6.9, $\mathrm{C}(\alpha) H), 4.12-4.17$ (1H, dd, $J$ 12.4, 4.9, C(5) $\left.H_{\mathrm{A}}\right), 4.43$ (1H, dd, J 12.4, 4.9, C(5)HB ), 6.95-7.05 (5H, m, Ph), 7.20-7.43 (15H, m, Ph); $\delta_{\mathrm{C}}(100 \mathrm{MHz}$, $\left.\left.\mathrm{CDCl}_{3}\right) 14.9(\mathrm{C}(\alpha) M e), 34.4(C(2)), 50.4\left(\mathrm{NCH}_{2} \mathrm{Ph}\right), 53.3(C(3)), 54.7\left(\mathrm{~N}_{(} \mathrm{CH}_{2} \mathrm{Ph}\right)_{2}\right), 56.5(C(\alpha)), 58.1(C(4))$, 66.0 (C(5)), 127.0, 127.1, 128.2, 128.2, 128.2, 128.3, 128.8, 129.0, 129.0 (o,m,p-Ph), 139.1, 139.5, 143.4 (i-

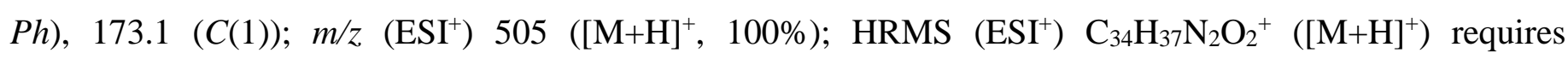
505.2850; found 505.2846.

\section{$(3 R, 4 R, \alpha S)-3-[N-$ Benzyl- $N$-( $\alpha$-methylbenzyl)amino]-4-( $N, N$-dibenzylamino)-5-}

(triisopropylsilyloxy)pentan-1-ol 62. $\mathrm{LiAlH}_{4}(1.0 \mathrm{M}$ in THF, $1.1 \mathrm{~mL}, 1.1 \mathrm{mmol}$ ) was added to a stirred solution of an 87:13 mixture of 49 and 50 (200 mg, $0.272 \mathrm{mmol})$ in THF (13 mL) at $-78{ }^{\circ} \mathrm{C}$ and the resultant solution was stirred at rt for $18 \mathrm{~h}$. The resultant solution was cooled to $0{ }^{\circ} \mathrm{C}, 1 \mathrm{M}$ aq $\mathrm{NaOH}(1 \mathrm{~mL})$ was added and the resultant biphasic mixture was stirred at $67^{\circ} \mathrm{C}$ for $1 \mathrm{~h}$, then filtered through Celite ${ }^{\circledR}$ (eluent EtOAc), dried and concentrated in vacuo to give an 87:13 mixture of $\mathbf{6 2}$ and $\mathbf{6 3}$, respectively. Purification via flash column chromatography $\left(30-40^{\circ} \mathrm{C}\right.$ petroleum ether/EtOAc, 5:1) gave 62 as a colourless oil (115 mg, 64\%, >99:1 dr); $[\alpha]_{\mathrm{D}}^{22}+24.8\left(c 1.0\right.$ in $\left.\mathrm{CHCl}_{3}\right) ; v_{\max } 3410(\mathrm{O}-\mathrm{H}) ; \delta_{\mathrm{H}}\left(400 \mathrm{MHz}\right.$, benzene- $\left.d_{6}\right) 1.13(3 \mathrm{H}, \mathrm{d}$, 
$J$ 6.8, C $(\alpha) M e), 1.22-1.28$ (21H, m, Si (CHMe $\left.)_{3}\right), 1.50-1.57\left(1 \mathrm{H}, \mathrm{m}, \mathrm{C}(2) H_{\mathrm{A}}\right), 1.60-1.67\left(1 \mathrm{H}, \mathrm{m}, \mathrm{C}(2) H_{\mathrm{B}}\right)$, $2.24\left(1 \mathrm{H}\right.$, br s, OH), 2.82-2.88 (1H, m, C(3)H), 3.26-3.34 (1H, m, C(4)H), 3.35-3.42 (1H, m, NCH $\left.\mathrm{A}_{\mathrm{B}} \mathrm{Ph}\right)$, 3.45-3.55 (3H, m, C(1) $\left.H_{2}, \mathrm{NCH}_{\mathrm{A}} H_{\mathrm{B}} \mathrm{Ph}\right), 3.66(1 \mathrm{H}, \mathrm{q}, J$ 6.8, C $(\alpha) H), 3.80-3.88\left(2 \mathrm{H}, \mathrm{m}, \mathrm{N}\left(\mathrm{CH}_{\mathrm{A}} \mathrm{H}_{\mathrm{B}} \mathrm{Ph}\right)_{2}\right)$, 3.93-4.13 (3H, m, C(5)H $\left.H_{\mathrm{A}}, \mathrm{N}\left(\mathrm{CH}_{\mathrm{A}} H_{\mathrm{B}} \mathrm{Ph}\right)_{2}\right)$, 4.58 (1H, dd, J 10.9, 3.9, C(5)HB ), 7.05-7.09 (4H, m, Ph), 7.177.27 (10H, m, Ph), 7.34 (2H, d, J 7.3, Ph), 7.49 (4H, d, J 7.3, Ph); $\delta_{\mathrm{C}}\left(100 \mathrm{MHz}\right.$, benzene- $\left.d_{6}\right) 12.8$ (Si(CHMe $\left.)_{3}\right), 18.9\left(\mathrm{Si}(\mathrm{CHMe})_{3}\right), 23.0(\mathrm{C}(\alpha) M e), 32.4$ (C(2)), $\left.53.2\left(\mathrm{NCH}_{2} \mathrm{Ph}\right), 55.9\left(\mathrm{~N}_{(} \mathrm{CH}_{2} \mathrm{Ph}\right)_{2}\right), 56.3$ $(C(1)), 56.9(C(3)), 61.3(C(\alpha)), 62.5(C(4)), 66.3(C(5)), 127.2,127.6,127.8-129.5,131.0(o, m, p-P h)$, 140.7, 142.7, $146.4(\mathrm{i}-\mathrm{Ph}) ; \mathrm{m} / \mathrm{z}\left(\mathrm{ESI}^{+}\right) 665\left([\mathrm{M}+\mathrm{H}]^{+}, 100 \%\right) ; \mathrm{HRMS}\left(\mathrm{ESI}^{+}\right) \mathrm{C}_{43} \mathrm{H}_{61} \mathrm{~N}_{2} \mathrm{O}_{2} \mathrm{Si}^{+}\left([\mathrm{M}+\mathrm{H}]^{+}\right)$ requires 665.4497 ; found 665.4492 .

(2R,3R)-1-Triisopropylsilyloxy-2,3-di-(N-tert-butoxycarbonylamino)pentan-5-ol 64. Boc $2 \mathrm{O}$ (985 $\mathrm{mg}, 4.51 \mathrm{mmol})$ and $\mathrm{Pd}(\mathrm{OH})_{2} / \mathrm{C}(40 \% \mathrm{w} / \mathrm{w}$ of substrate, $400 \mathrm{mg})$ were added sequentially to a vigorously stirred solution of $62(1.00 \mathrm{~g}, 1.50 \mathrm{mmol}$, >99:1 dr) in degassed $\mathrm{MeOH}(5 \mathrm{~mL})$ at rt and the resultant suspension was stirred under $\mathrm{H}_{2}(5 \mathrm{~atm})$ at rt for $72 \mathrm{~h}$, then filtered through Celite ${ }^{\circledR}$ (eluent MeOH) and concentrated in vacuo. Purification via flash column chromatography (eluent $30-40{ }^{\circ} \mathrm{C}$ petroleum ether/Et $2 \mathrm{O}, 3: 1$; increased to $30-40{ }^{\circ} \mathrm{C}$ petroleum ether/Et $\left.t_{2} \mathrm{O}, 1: 1\right)$ gave 64 as a pale yellow oil (606 mg, 82\%, >99:1 dr); $[\alpha]_{\mathrm{D}}^{22}+19.8$ (c 1.0 in $\left.\mathrm{CHCl}_{3}\right) ; v_{\max } 3355(\mathrm{~N}-\mathrm{H}, \mathrm{O}-\mathrm{H}), 1684(\mathrm{C}=\mathrm{O}) ; \delta_{\mathrm{H}}\left(400 \mathrm{MHz}, \mathrm{CDCl}_{3}\right)$ 1.02-1.19 (21H, m, Si(CHMe $\left.)_{3}\right), 1.40-1.50$ (19H, m, C(4)HA, CMe $), 1.77-1.87\left(1 \mathrm{H}, \mathrm{m}, \mathrm{C}(4) H_{\mathrm{B}}\right), 3.56-$ 3.74 (3H, m, C(2)H, C(5)H $\left.H_{2}\right), 3.88$ (1H, d, J 13.0, C(1)H $\left.H_{\mathrm{A}}\right), 3.93-4.04$ (3H, m, C(1)H $\left.H_{\mathrm{B}}, \mathrm{C}(3) H\right), 5.12(1 \mathrm{H}, \mathrm{d}$, J 8.5, $\mathrm{NH}), 5.94(1 \mathrm{H}, \mathrm{d}, J$ 9.2, $\mathrm{NH})$; $\delta_{\mathrm{C}}\left(100 \mathrm{MHz}, \mathrm{CDCl}_{3}\right) 11.7\left(\mathrm{Si}\left(\mathrm{CHMe}_{2}\right)_{3}\right), 17.9\left(\mathrm{Si}(\mathrm{CHMe})_{3}\right), 28.3,28.4$ (CMe3), 36.3 (C(4)), 50.0 (C(3)), 53.1 (C(2)), 58.4 (C(5)), 63.5 (C(1)), 79.7, 79.8 (CMe ), 155.4, 157.5 (NCO); m/z $\left(\mathrm{ESI}^{+}\right) 513\left([\mathrm{M}+\mathrm{Na}]^{+}, 100 \%\right) ; \mathrm{HRMS}\left(\mathrm{ESI}^{+}\right) \mathrm{C}_{24} \mathrm{H}_{50} \mathrm{~N}_{2} \mathrm{NaO}_{6} \mathrm{Si}^{+}\left([\mathrm{M}+\mathrm{Na}]^{+}\right)$requires 513.3330; found 513.3341.

(2R,3R)-1-Triisopropylsilyloxy-2,3-di-( $N$-tert-butoxycarbonylamino)-5-(1'-phenyl-1H-tetrazol5'-ylthio)pentane 66. Method A. Mitsunobu Reaction. DEAD (42 $\mu \mathrm{L}, 0.265$ mmol), $\mathrm{PPh}_{3}(64.1 \mathrm{mg}, 0.245$ mmol) and PTSH (182 mg, $1.02 \mathrm{mmol})$ were added sequentially to a stirred solution of 64 (100 mg, 0.204 mmol, $>99: 1 \mathrm{dr})$ in THF $(1.5 \mathrm{~mL})$ at $0{ }^{\circ} \mathrm{C}$ and the resultant solution was stirred at rt for $18 \mathrm{~h}$. The resultant solution was diluted with EtOAc (2 mL), washed sequentially with brine (2 mL) and $\mathrm{H}_{2} \mathrm{O}(2 \mathrm{~mL})$, then dried and concentrated in vacuo. Purification via flash column chromatography (eluent $\mathrm{CHCl}_{3} /{ }^{\mathrm{i}} \mathrm{PrOH}, 30: 1$ ) gave 66 as a colourless oil (80 mg, 60\%, >99:1 dr); $[\alpha]_{\mathrm{D}}^{22}+25.9$ (c 1.0 in $\left.\mathrm{CHCl}_{3}\right) ; v_{\max } 3357(\mathrm{~N}-\mathrm{H}), 1687(\mathrm{C}=\mathrm{O})$; $\delta_{\mathrm{H}}\left(400 \mathrm{MHz}, \mathrm{CDCl}_{3}\right)$ 1.10-1.15 (21H, m, Si(CHMe $\left.)_{3}\right), 1.43\left(18 \mathrm{H}, \mathrm{s}, \mathrm{CM} e_{3}\right), 1.96-2.07\left(1 \mathrm{H}, \mathrm{m}, \mathrm{C}(4) H_{\mathrm{A}}\right)$, 2.10-2.27 (1H, m, C(4)HB ), 3.26-3.35 (1H, m, C(5)H $\left.H_{\mathrm{A}}\right)$, 3.55-3.70 (2H, m, C(2)H, C(5)HB), 3.85 (1H, app d, $J$ 10.6, C(1)H $\left.H_{\mathrm{A}}\right), 3.99$ (1H, dd, $J$ 10.6, 2.1, C(1)HB ), 4.01-4.06 (1H, m, C(3)H), $5.11(1 \mathrm{H}, \mathrm{d}, J$ 8.5, NH), 
$5.75\left(1 \mathrm{H}, \mathrm{d}, J\right.$ 9.5, NH), 7.50-7.62 (5H, m, Ph); $\delta_{\mathrm{C}}\left(100 \mathrm{MHz}, \mathrm{CDCl}_{3}\right) 11.7\left(\mathrm{Si}\left(\mathrm{CHMe}_{2}\right)_{3}\right), 18.0$ (Si(CHMe $\left.)_{3}\right)$ ), 28.3, 28.3 (CMe3), 30.3 (C(5)), 33.7 (C(4)), 52.2 (C(2)), $52.7(C(3)), 63.5(C(1)), 79.3,79.6$ (CMe $)$, 123.9, 129.8, 130.0 (o,m,p-Ph), 133.7 (i-Ph), 154.4 (C(5')), 155.4, 156.3 (NCO); m/z (ESI $) 673$ $\left([\mathrm{M}+\mathrm{Na}]^{+}, 100 \%\right), 651\left([\mathrm{M}+\mathrm{H}]^{+}, 47 \%\right) ; \mathrm{HRMS}\left(\mathrm{ESI}^{+}\right) \mathrm{C}_{31} \mathrm{H}_{55} \mathrm{~N}_{6} \mathrm{O}_{5} \mathrm{SSi}^{+}\left([\mathrm{M}+\mathrm{H}]^{+}\right)$requires 651.3718; found 651.3716.

Method B. Mesylation/displacement. Step 1. Et $\mathrm{H}_{3} \mathrm{~N}$ (606 $\left.\mu \mathrm{L}, 4.35 \mathrm{mmol}\right), \mathrm{MsCl}(135 \mu \mathrm{L}, 1.74 \mathrm{mmol})$ and DMAP (10.6 mg, $0.087 \mathrm{mmol}$ ) were added sequentially to a stirred solution of 64 (427 mg, $0.870 \mathrm{mmol}$, >99:1 dr) in $\mathrm{CH}_{2} \mathrm{Cl}_{2}(26 \mathrm{~mL})$ at rt and the resultant solution was stirred at rt for $3 \mathrm{~h} . \mathrm{H}_{2} \mathrm{O}(15 \mathrm{~mL})$ was added and the aqueous layer was extracted with $\mathrm{CH}_{2} \mathrm{Cl}_{2}(3 \times 10 \mathrm{~mL})$. The combined organics were washed sequentially with $1 \mathrm{M}$ aq $\mathrm{HCl}(50 \mathrm{~mL})$, satd aq $\mathrm{NaHCO}_{3}(50 \mathrm{~mL})$ and brine $(50 \mathrm{~mL})$, then dried and concentrated in vacuo to give $\mathbf{6 5}$ as a colourless oil (450 mg).

Step 2. PTSH (171 mg, $0.957 \mathrm{mmol})$ and $\mathrm{K}_{2} \mathrm{CO}_{3}(240 \mathrm{mg}, 1.74 \mathrm{mmol}$ ) were added sequentially to a stirred solution of the residue 65 (450 $\mathrm{mg})$ from the previous step in acetone $(8 \mathrm{~mL})$ at $\mathrm{rt}$ and the resultant solution was stirred at $67^{\circ} \mathrm{C}$ for $2.5 \mathrm{~h}$, then allowed to cool rt and filtered. $\mathrm{CH}_{2} \mathrm{Cl}_{2}(10 \mathrm{~mL})$ and $\mathrm{H}_{2} \mathrm{O}(10 \mathrm{~mL})$ were added, and the aqueous layer was extracted with $\mathrm{CH}_{2} \mathrm{Cl}_{2}(3 \times 10 \mathrm{~mL})$. The combined organics were washed with $\mathrm{H}_{2} \mathrm{O}(3 \times 25 \mathrm{~mL})$, then dried and concentrated in vacuo. Purification via flash column chromatography (eluent $30-40{ }^{\circ} \mathrm{C}$ petroleum ether/EtOAc, 6:1) gave 66 as a pale yellow oil (458 mg, 81\%, $>99: 1 \mathrm{dr})$.

(2R,3R)-1-Triisopropylsilyloxy-2,3-di-( $N$-tert-butoxycarbonylamino)-5-(1'-phenyl-1H-tetrazol-

5'-ylsulfonyl)pentane 67. A solution of 66 (383 mg, $0.588 \mathrm{mmol},>99: 1 \mathrm{dr})$ in EtOH (10 mL) was added dropwise to a stirred solution of $\left(\mathrm{NH}_{4}\right)_{2} \mathrm{Mo}_{7} \mathrm{O}_{24} \cdot 4 \mathrm{H}_{2} \mathrm{O}(146 \mathrm{mg}, 0.118 \mathrm{mmol})$ in $30 \%$ aq $\mathrm{H}_{2} \mathrm{O}_{2}(1.00 \mathrm{~mL}, 8.86$ $\mathrm{mmol})$ at $0^{\circ} \mathrm{C}$ and the resultant solution was stirred at $\mathrm{rt}$ for $18 \mathrm{~h}$. Brine $(10 \mathrm{~mL})$ was added and the aqueous layer was extracted with EtOAc $(3 \times 20 \mathrm{~mL})$. The combined organics were dried and concentrated in vacuo. Purification via flash column chromatography (eluent $30-40{ }^{\circ} \mathrm{C}$ petroleum ether/EtOAc, 5:1) gave 67 as a white solid (374 mg, 93\%, >99:1 dr); mp 95-97 ${ }^{\circ} \mathrm{C}$; $[\alpha]_{\mathrm{D}}^{22}-1.2$ (c 1.0 in $\left.\mathrm{CHCl}_{3}\right)$; $v_{\max } 3355(\mathrm{~N}-\mathrm{H}), 1684$ $(\mathrm{C}=\mathrm{O}), 1164(\mathrm{~S}=\mathrm{O}) ; \delta_{\mathrm{H}}\left(400 \mathrm{MHz}, \mathrm{CDCl}_{3}\right)$ 1.00-1.18 (21H, m, Si(CHMe $\left.)_{3}\right), 1.41-1.46\left(18 \mathrm{H}, \mathrm{m}, \mathrm{CMe}_{3}\right)$, 2.04-2.15 (1H, m, C $\left.(4) H_{\mathrm{A}}\right), 2.19-2.30\left(1 \mathrm{H}, \mathrm{m}, \mathrm{C}(4) H_{\mathrm{B}}\right), 3.64-3.72(1 \mathrm{H}, \mathrm{m}, \mathrm{C}(2) H), 3.76-3.91$ (3H, m, C(1) $\left.H_{\mathrm{A}}, \mathrm{C}(5) H_{2}\right), 3.91-4.01\left(2 \mathrm{H}, \mathrm{m}, \mathrm{C}(1) H_{\mathrm{B}}, \mathrm{C}(3) H\right), 5.07(1 \mathrm{H}, \mathrm{d}, J$ 8.4, NH), $5.66(1 \mathrm{H}, \mathrm{d}, J$ 9.0, NH), 7.50$7.65(5 \mathrm{H}, \mathrm{m}, \mathrm{Ph}) ; \delta_{\mathrm{C}}\left(100 \mathrm{MHz}, \mathrm{CDCl}_{3}\right) 11.7\left(\mathrm{Si}\left(\mathrm{CHMe}_{2}\right)_{3}\right), 18.0\left(\mathrm{Si}(\mathrm{CHMe})_{3}\right), 28.3\left(\mathrm{CMe}_{3}\right), 29.7(\mathrm{C}(4))$, 51.8 (C(3)), 53.1 (C(2)), 53.8 (C(5)), 63.3 (C(1)), 79.8, $80.0\left(C \mathrm{Me}_{3}\right), 125.1,129.7,131.4($ o,m,p-Ph), 133.0 (i-Ph), 153.3, 155.5, 156.1 (C(5'), NCO); m/z (ESI $\left.{ }^{+}\right) 705$ ([M+Na] $\left.]^{+}, 100 \%\right), 683$ (27\%), 527 (66\%); HRMS $\left(\mathrm{ESI}^{+}\right) \mathrm{C}_{31} \mathrm{H}_{54} \mathrm{~N}_{6} \mathrm{NaO}_{7} \mathrm{SSi}^{+}\left([\mathrm{M}+\mathrm{Na}]^{+}\right)$requires 705.3436; found 705.3442. 
(2R,3R,Z)-1-triisopropylsiloxy-2,3-di-(N-tert-butoxycarbonylamino)octadec-5-ene 69. Tridecanal (139 $\mu \mathrm{L}, 0.584 \mathrm{mmol})$ and LiHMDS (1.0 $\mathrm{M}$ in THF, $2.36 \mathrm{~mL}, 2.36 \mathrm{mmol})$ were added sequentially to a stirred solution of 67 (400 mg, $0.614 \mathrm{mmol},>99: 1 \mathrm{dr})$ in THF $(2 \mathrm{~mL})$ at $-10{ }^{\circ} \mathrm{C}$ and the resultant solution was stirred at rt for $18 \mathrm{~h}$. The resultant solution was cooled to $0{ }^{\circ} \mathrm{C}$ and then satd aq $\mathrm{NH}_{4} \mathrm{Cl}(1 \mathrm{~mL})$ and brine $(5$ $\mathrm{mL})$ were added sequentially. The aqueous layer was extracted with $\mathrm{Et}_{2} \mathrm{O}(3 \times 5 \mathrm{~mL})$ and then the combined organics were dried and concentrated in vacuo to give a 50:50 mixture of $\mathbf{6 8}$ and $\mathbf{6 9}$. Purification via flash column chromatography (eluent $30-40{ }^{\circ} \mathrm{C}$ petroleum ether/Et $2 \mathrm{O}, 10: 1$ ) gave a 50:50 mixture of $\mathbf{6 8}$ and $\mathbf{6 9}$ as a colourless oil (291 mg, 80\%); $v_{\max } 3365(\mathrm{~N}-\mathrm{H}), 1687(\mathrm{C}=\mathrm{O}) ; \delta_{\mathrm{H}}\left(500 \mathrm{MHz}, \mathrm{CDCl}_{3}\right)$ 0.85-0.90 (6H, m, $\left.\mathrm{C}(18) H_{3}\right), 1.03-1.14$ (42H, m, Si(CHMe $\left.)_{3}\right), 1.21-1.31$ (40H, m, C(8)H $\left.H_{2}-\mathrm{C}(17) H_{2}\right), 1.39-1.47$ (36H, m, $\mathrm{CMe}_{3}$ ), 1.92-1.98 (2H, m, C(7)H [68]), 1.98-2.05 (2H, m, C(7)H [69]), 2.17-2.27 (2H, m, C(4)HA), 2.29$2.43\left(2 \mathrm{H}, \mathrm{m}, \mathrm{C}(4) \mathrm{H}_{\mathrm{B}}\right), 3.62-3.68$ (2H, m, C(2)H), 3.76-3.69 (4H, m, C(1)H $\left.H_{\mathrm{A}}, \mathrm{C}(3) H\right)$, 3.93-3.99 (2H, m, C(1)Hв), 5.09-5.14 (2H, m, NH), 5.32-5.40 (2H, m, C(5)H), 5.43-5.51 (2H, m, C(6)H), 5.54-5.64 (2H, m, $\mathrm{NH}) ; \delta_{\mathrm{C}}\left(125 \mathrm{MHz}, \mathrm{CDCl}_{3}\right) 11.7\left(\mathrm{Si}\left(\mathrm{CHMe}_{2}\right)_{3}\right), 14.1$ (C(18)), 18.0, $18.0\left(\mathrm{Si}(\mathrm{CHMe})_{3}\right), 22.7(C(17)), 27.6$ (C(7) [69]), 28.4, 28.4 (CMes), 29.2, 29.3, 29.4, 29.5, 29.6, 29.6, 29.7, 30.3 (C(8)-C(16)), 31.2 (C(4) [69]), 31.9 (C(8)-C(16)), 32.6 (C(7) [68]), 36.7 (C(4) [68]), 51.5, $51.6(C(2)), 53.1,53.4(C(3)), 63.2,63.3(C(1))$, 124.8 (C(5) [69]), 125.4 (C(5) [68]), 132.7 (C(6) [69]), 134.0 (C(6) [68]), 155.3, 155.9 (NCO); m/z (ESI $\left.{ }^{+}\right)$ $677\left([\mathrm{M}+\mathrm{Na}]^{+}, 100 \%\right), 499$ (59\%); HRMS $\left(\mathrm{ESI}^{+}\right) \mathrm{C}_{37} \mathrm{H}_{74} \mathrm{~N}_{2} \mathrm{NaO}_{5} \mathrm{Si}^{+}\left([\mathrm{M}+\mathrm{Na}]^{+}\right)$requires 677.5259; found 677.5250.

(2R,3R)-1-Triisopropylsilyloxy-2,3-diacetamidooctadecane 71. Step 1. Pd/C (20\% w/w of substrate, $12 \mathrm{mg}$ ) was added to a vigorously stirred suspension of a 50:50 mixture of 68 and 69 (59 mg, $0.090 \mathrm{mmol})$ in degassed $\mathrm{MeOH}(1.5 \mathrm{~mL})$ at rt. The resultant suspension was stirred under $\mathrm{H}_{2}(5 \mathrm{~atm})$ at $\mathrm{rt}$ for $3 \mathrm{~h}$, then filtered through Celite ${ }^{\circledR}$ (eluent $\mathrm{MeOH}$ ) and concentrated in vacuo to give $\mathbf{7 0}$ as a pale yellow viscous oil (53 mg).

Step 2. TFA ( $69 \mu \mathrm{L}, 0.90 \mathrm{mmol}$ ) was added to a stirred solution of the residue $\mathbf{7 0}$ from the previous step (53 mg) in $\mathrm{CH}_{2} \mathrm{Cl}_{2}(1.5 \mathrm{~mL})$ at $\mathrm{rt}$ and the resultant solution was stirred at rt for $18 \mathrm{~h}$, then concentrated in vacuo to give a pale yellow oil (93 mg).

Step 3. $\mathrm{Ac}_{2} \mathrm{O}(0.13 \mathrm{~mL}, 1.4 \mathrm{mmol})$ was added to a stirred solution of the residue from the previous step (93 mg) and DMAP (1 mg, $9 \mu \mathrm{mol})$ in pyridine $(0.25 \mathrm{~mL}, 3.2 \mathrm{mmol})$ at rt, and the resultant solution was stirred at rt for $24 \mathrm{~h}$. EtOAc $(10 \mathrm{~mL})$ was added, the resultant solution was washed with satd aq $\mathrm{CuSO}_{4}(2 \times$ $5 \mathrm{~mL})$, and the aqueous layer was extracted with EtOAc $(2 \times 5 \mathrm{~mL})$. The combined organics were washed with satd aq $\mathrm{NaHCO}_{3}(15 \mathrm{~mL})$, then dried and concentrated in vacuo. Purification via flash column 
chromatography (eluent $\mathrm{CHCl}_{3} / \mathrm{PrOH} / 35 \%$ aq $\mathrm{NH}_{4} \mathrm{OH}, 90: 3: 1$ ) gave 71 as a white solid (35 mg, 72\%, >99:1 dr); mp 146-149 ${ }^{\circ} \mathrm{C} ;[\alpha]_{\mathrm{D}}^{22}+45.7$ ( c 1.0 in $\left.\mathrm{CHCl}_{3}\right) ; v_{\max } 3270(\mathrm{~N}-\mathrm{H}), 1643(\mathrm{C}=\mathrm{O}) ; \delta_{\mathrm{H}}\left(500 \mathrm{MHz}, \mathrm{CDCl}_{3}\right)$ 0.89 (3H, t, J 7.0, C(18)H $\left.H_{3}\right), 1.06-1.14$ (21H, m, Si(CHMe $\left.)_{3}\right), 1.22-1.33$ (26H, m, C(5)H $\left.H_{2}-\mathrm{C}(17) H_{2}\right), 1.46-$ 1.56 (2H, m, C(4)H $), 1.99$ (3H, s, COMe), 2.00 (3H, s, COMe), 3.85 (1H , dd, J 10.4, 3.9, C(1)HA), 3.93$3.99\left(2 \mathrm{H}, \mathrm{m}, \mathrm{C}(1) H_{\mathrm{B}}, \mathrm{C}(2) H\right), 4.06-4.13(1 \mathrm{H}, \mathrm{m}, \mathrm{C}(3) H), 6.16\left(1 \mathrm{H}, \mathrm{d}, J\right.$ 7.6, NH), $6.50\left(1 \mathrm{H}, \mathrm{d}, J\right.$ 9.2, NH); $\delta_{\mathrm{C}}$ (125 MHz, $\left.\mathrm{CDCl}_{3}\right) 11.7\left(\mathrm{Si}\left(\mathrm{CHMe}_{2}\right)_{3}\right), 14.1$ (C(18)), 17.9 (Si(CHMe$\left.)_{3}\right), 22.7(C(17)), 26.2$, 29.3, 29.4, 29.5, 29.5, 29.6-29.7, 32.0 (C(5)-C(16)), 23.4, 23.5 (COMe), 33.2 (C(4)), $52.1(C(2)), 52.3(C(3)), 63.1(C(1))$, 169.9 (COMe), 170.3 (COMe); m/z $\left(\mathrm{ESI}^{+}\right) 541\left([\mathrm{M}+\mathrm{H}]^{+}, 100 \%\right) ; \mathrm{HRMS}\left(\mathrm{ESI}^{+}\right) \mathrm{C}_{31} \mathrm{H}_{65} \mathrm{~N}_{2} \mathrm{O}_{3} \mathrm{Si}^{+}\left([\mathrm{M}+\mathrm{H}]^{+}\right)$ requires 541.4759; found 541.4753.

\section{(2R,3R,4R, $\alpha R)-2-H y d r o x y-3-[N$-benzyl- $N$-( $\alpha$-methylbenzyl)amino]-4-( $N, N$-dibenzylamino)-5-}

pentanolactone 73 . TBAF (1.0 M in THF, $10.6 \mathrm{~mL}, 10.6 \mathrm{mmol})$ was added to a stirred solution of $(2 R, 3 R, 4 R, \alpha R)-51(3.96 \mathrm{~g}, 5.28 \mathrm{mmol},>99: 1 \mathrm{dr})$ in THF $(80 \mathrm{~mL})$ at $0{ }^{\circ} \mathrm{C}$ and the resultant solution was stirred at rt for $24 \mathrm{~h}$. $\mathrm{Et}_{2} \mathrm{O}(40 \mathrm{~mL})$ and $\mathrm{H}_{2} \mathrm{O}(40 \mathrm{~mL})$ were added and the aqueous layer was extracted with $\mathrm{Et}_{2} \mathrm{O}(3 \times 200 \mathrm{~mL})$. The combined organics were washed with satd aq $\mathrm{NaHCO}_{3}(150 \mathrm{~mL})$, then dried and concentrated in vacuo. Purification via flash column chromatography (eluent $30-40{ }^{\circ} \mathrm{C}$ petroleum ether/EtOAc, 20:1; increased to $30-40{ }^{\circ} \mathrm{C}$ petroleum ether/EtOAc, 5:1) gave 73 as a white foam (1.67 $\mathrm{g}$, 61\%, >99:1 dr); $\mathrm{C}_{34} \mathrm{H}_{36} \mathrm{~N}_{2} \mathrm{O}_{3}$ requires C, 78.4; H, 7.0; N, 5.4\%; found C, 78.4; H, 6.95; N, 5.4\%; $[\alpha]_{D}^{20}-14.3$

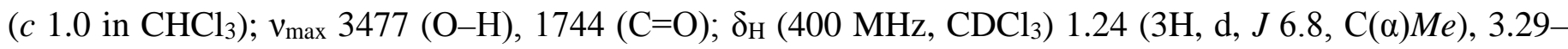
$3.40(2 \mathrm{H}, \mathrm{m}, \mathrm{C}(3) \mathrm{H}, \mathrm{C}(4) \mathrm{H})$ overlapping 3.34 (2H, d, J 12.9, N( $\left.\left.\mathrm{CH}_{\mathrm{A}} \mathrm{H}_{\mathrm{B}} \mathrm{Ph}\right)_{2}\right), 3.67-3.76\left(2 \mathrm{H}, \mathrm{m}, \mathrm{NCH}_{2} \mathrm{Ph}\right)$ overlapping $3.73\left(2 \mathrm{H}, \mathrm{d}, J\right.$ 12.9, $\left.\mathrm{N}\left(\mathrm{CH}_{\mathrm{A}} H_{\mathrm{B}} \mathrm{Ph}\right)_{2}\right), 3.93\left(1 \mathrm{H}, \mathrm{dd}, J\right.$ 13.0, 3.3, C(5)H $\left.\mathrm{H}_{\mathrm{A}}\right), 4.24(1 \mathrm{H}, \mathrm{q}, J$ 6.8, $\mathrm{C}(\alpha) H), 4.34(1 \mathrm{H}, \mathrm{d}, J 10.9, \mathrm{C}(2) H), 4.67$ (1H, app d, $J$ 13.0, C(5)HB $) 7.01-7.42(20 \mathrm{H}, \mathrm{m}, P h) ; \delta_{\mathrm{C}}(100 \mathrm{MHz}$, $\left.\mathrm{CDCl}_{3}\right) 20.3(\mathrm{C}(\alpha) M e), 51.1\left(\mathrm{NCH}_{2} \mathrm{Ph}\right), 54.7\left(\mathrm{~N}\left(\mathrm{CH}_{2} \mathrm{Ph}\right)_{2}\right), 56.7(C(3)), 61.0(C(\alpha)), 62.6(C(4)), 63.9(C(5))$, $68.4(C(2)), 126.8,127.1,127.4,128.0,128.1,128.4,128.4,129.2$ (o,m,p-Ph), 138.7, 140.8, $145.0(i-P h)$, $174.5(C(1)) ; m / z\left(\mathrm{ESI}^{+}\right) 543\left([\mathrm{M}+\mathrm{Na}]^{+}, 40 \%\right), 521\left([\mathrm{M}+\mathrm{H}]^{+}, 100 \%\right) ; \mathrm{HRMS}\left(\mathrm{ESI}^{+}\right) \mathrm{C}_{34} \mathrm{H}_{37} \mathrm{~N}_{2} \mathrm{O}_{3}{ }^{+}\left([\mathrm{M}+\mathrm{H}]^{+}\right)$ requires 521.2799; found 521.2780.

tert-Butyl

$(2 R, 3 R, 4 R, \alpha R)-2-b e n z y l o x y-3-[N$-benzyl- $N$-( $\alpha$-methylbenzyl)amino]-4-( $N, N$ dibenzylamino)-5-(triisopropylsilyloxy)pentanoate 77. $\mathrm{NaH}$ (60\% dispersion in mineral oil, $82 \mathrm{mg}, 2.06$ mmol) was added to a stirred solution of (2R,3R,4R, $\alpha R)-51$ (910 mg, $1.21 \mathrm{mmol},>99: 1 \mathrm{dr})$ in THF (10 mL) at $0{ }^{\circ} \mathrm{C}$ and the resultant solution was stirred at $0{ }^{\circ} \mathrm{C}$ for $30 \mathrm{~min}$. $\mathrm{BnBr}(288 \mu \mathrm{L}, 2.42 \mathrm{mmol})$ was then added and the resultant solution was stirred at rt for $24 \mathrm{~h}$. Satd aq $\mathrm{NH}_{4} \mathrm{Cl}(2 \mathrm{~mL})$ was then added and the organic layer was washed sequentially with brine $(15 \mathrm{~mL})$ and $\mathrm{H}_{2} \mathrm{O}(15 \mathrm{~mL})$. The combined aqueous layers were extracted with $\mathrm{Et}_{2} \mathrm{O}(3 \times 25 \mathrm{~mL})$, then the combined organics were dried and concentrated in vacuo. 
Purification via flash column chromatography (eluent $30-40{ }^{\circ} \mathrm{C}$ petroleum ether, neat; increased to $30-40$ ${ }^{\circ} \mathrm{C}$ petroleum ether/EtOAc, 20:1) gave 77 as a pale yellow oil (863 mg, 85\%, >99:1 dr); $[\alpha]_{\mathrm{D}}^{22}+20.4(c 1.0$ in $\left.\mathrm{CHCl}_{3}\right) ; v_{\max } 1735(\mathrm{C}=\mathrm{O}) ; \delta_{\mathrm{H}}\left(400 \mathrm{MHz}, \mathrm{CDCl}_{3}\right)$ 0.97-1.12 (21H, m, Si(CHMe $\left.)_{3}\right), 1.37$ (3H, d, J 6.7, $\mathrm{C}(\alpha) M e), 1.52(9 \mathrm{H}, \mathrm{s}, \mathrm{CMe} 3), 3.53-3.63(2 \mathrm{H}, \mathrm{m}, \mathrm{C}(4) H, \mathrm{C}(\alpha) H), 3.67\left(1 \mathrm{H}, \mathrm{d}, J\right.$ 15.3, $\left.\mathrm{NCH}_{\mathrm{A}} \mathrm{H}_{\mathrm{B}} \mathrm{Ph}\right)$, 3.73-3.80 (2H, m, C(2)H, $\left.\mathrm{NCH}_{\mathrm{A}} H_{\mathrm{B}} \mathrm{Ph}\right), 3.81-3.89\left(3 \mathrm{H}, \mathrm{m}, \mathrm{C}(3) \mathrm{H}, \mathrm{N}\left(\mathrm{CH}_{\mathrm{A}} \mathrm{H}_{\mathrm{B}} \mathrm{Ph}\right)_{2}\right), 3.93-4.02(3 \mathrm{H}, \mathrm{m}$, $\left.\mathrm{OCH}_{\mathrm{A}} \mathrm{H}_{\mathrm{B}} \mathrm{Ph}, \mathrm{N}\left(\mathrm{CH}_{\mathrm{A}} H_{\mathrm{B}} \mathrm{Ph}\right)_{2}\right), 4.02-4.12\left(2 \mathrm{H}, \mathrm{m}, \mathrm{C}(5) H_{2}\right), 4.52\left(1 \mathrm{H}, \mathrm{d}, J 10.6, \mathrm{OCH}_{\mathrm{A}} H_{\mathrm{B}} \mathrm{Ph}\right), 6.98-7.13(10 \mathrm{H}$, m, Ph), 7.19-7.32 (11H, m, Ph), 7.36-7.42 (4H, m, Ph); $\delta_{\mathrm{C}}\left(100 \mathrm{MHz}, \mathrm{CDCl}_{3}\right) 11.9\left(\mathrm{Si}\left(\mathrm{CHMe}_{2}\right)_{3}\right), 18.2$ (Si(CHMe $\left.)_{3}\right), 21.5(\mathrm{C}(\alpha) M e), 28.1\left(\mathrm{CMe}_{3}\right), 53.0\left(\mathrm{NCH}_{2} \mathrm{Ph}\right), 55.0\left(\mathrm{~N}\left(\mathrm{CH}_{2} \mathrm{Ph}\right)_{2}\right), 59.1(\mathrm{C}(\alpha)), 61.2(C(4))$, $61.8(C(3)), 62.5(C(5)), 72.0\left(\mathrm{OCH}_{2} \mathrm{Ph}\right), 80.6(C(2)), 81.6\left(\mathrm{CMe}_{3}\right), 125.8,126.4,126.6,127.4,127.6,127.8$, 127.8, 128.1, 128.3, 128.4, 129.7, 129.7 (o,m,p-Ph), 137.7, 141.0, 141.5, 143.9 (i-Ph), $171.3(C(1)) ; \mathrm{m} / \mathrm{z}$ $\left(\mathrm{ESI}^{+}\right) 841\left([\mathrm{M}+\mathrm{H}]^{+}, 100 \%\right) ; \mathrm{HRMS}\left(\mathrm{ESI}^{+}\right) \mathrm{C}_{54} \mathrm{H}_{73} \mathrm{~N}_{2} \mathrm{O}_{4} \mathrm{Si}^{+}\left([\mathrm{M}+\mathrm{H}]^{+}\right)$requires 841.5334; found 841.5336.

tert-Butyl $\quad(2 R, 3 R, 4 R, \alpha R)-2-b e n z y l o x y-3-[N$-benzyl- $N$ - $(\alpha$-methylbenzyl)amino]-4- $(N, N$ dibenzylamino)-5-hydroxypentanoate 78. HF (70\% in pyridine, $463 \mu \mathrm{L}, 17.8 \mathrm{mmol}$ ) was added to a stirred solution of 77 (500 mg, $0.594 \mathrm{mmol},>99: 1 \mathrm{dr})$ in THF $(10 \mathrm{~mL})$ at $0{ }^{\circ} \mathrm{C}$ and the resultant mixture was stirred at rt for $18 \mathrm{~h}$. Satd aq $\mathrm{NaHCO}_{3}(10 \mathrm{~mL})$ was added and the aqueous layer was extracted with EtOAc $(3 \times 15$ $\mathrm{mL}$ ), then the combined organics were dried and concentrated in vacuo. Purification via flash column chromatography (eluent $30-40{ }^{\circ} \mathrm{C}$ petroleum ether/EtOAc, 8:1) gave 78 as a colourless oil (313 mg, 77\%, >99:1 dr); $[\alpha]_{\mathrm{D}}^{22}+2.6$ ( с 1.0 in $\left.\mathrm{CHCl}_{3}\right) ; v_{\max } 3527(\mathrm{O}-\mathrm{H}), 1734(\mathrm{C}=\mathrm{O}) ; \delta_{\mathrm{H}}\left(400 \mathrm{MHz}, \mathrm{CDCl}_{3}\right) 1.50(9 \mathrm{H}, \mathrm{s}$, $\left.\mathrm{CMe}_{3}\right), 1.62$ (3H, d, J 7.1, C( $\left.\left.\alpha\right) M e\right), 3.24$ (1H, br s, OH), 3.39-3.47 (2H, m, C(4)H, C(5)HA), 3.58-3.65 (2H, m, C(2)H, $\left.\mathrm{NCH}_{\mathrm{A}} \mathrm{H}_{\mathrm{B}} \mathrm{Ph}\right), 3.66-3.76\left(4 \mathrm{H}, \mathrm{m}, \mathrm{C}(5) \mathrm{H}_{\mathrm{B}}, \mathrm{N}\left(\mathrm{CH}_{\mathrm{A}} \mathrm{H}_{\mathrm{B}} \mathrm{Ph}\right)_{2}, \mathrm{OCH}_{\mathrm{A}} \mathrm{H}_{\mathrm{B}} \mathrm{Ph}\right), 3.84(2 \mathrm{H}, \mathrm{d}, J$ 13.4, $\left.\mathrm{N}\left(\mathrm{CH}_{\mathrm{A}} H_{\mathrm{B}} \mathrm{Ph}\right)_{2}\right), 4.02(1 \mathrm{H}$, app d, $J$ 7.2, C(3)H), $4.10(1 \mathrm{H}, \mathrm{q}, J$ 7.1, C( $\alpha) H), 4.40\left(1 \mathrm{H}, \mathrm{d}, J\right.$ 15.7, $\left.\mathrm{NCH}_{\mathrm{A}} H_{\mathrm{B}} \mathrm{Ph}\right)$, $4.53\left(1 \mathrm{H}, \mathrm{d}, J\right.$ 11.0, $\left.\mathrm{OCH}_{\mathrm{A}} H_{\mathrm{B}} \mathrm{Ph}\right), 7.13-7.40(25 \mathrm{H}, \mathrm{m}, \mathrm{Ph}) ; \delta_{\mathrm{C}}\left(100 \mathrm{MHz}, \mathrm{CDCl}_{3}\right) 21.5(\mathrm{C}(\alpha) M e), 28.1$ (CMe $), 51.9\left(\mathrm{NCH}_{2} \mathrm{Ph}\right), 54.4\left(\mathrm{~N}\left(\mathrm{CH}_{2} \mathrm{Ph}\right)_{2}\right), 57.7(C(\alpha)), 58.9(C(5)), 59.3(C(3)), 60.9(C(4)), 72.4$ $\left(\mathrm{OCH}_{2} \mathrm{Ph}\right), 79.1$ (C(2)), $82.3\left(\mathrm{CMe}_{3}\right), 126.6,126.9,127.1,127.5,127.5,128.1,128.2,128.2,128.3,128.3$, 128.5, 129.2 (o,m,p-Ph), 137.7, 140.1, 140.5, 142.5 (i-Ph), $171.6(C(1)) ; \mathrm{m} / \mathrm{z}\left(\mathrm{ESI}^{+}\right) 685\left([\mathrm{M}+\mathrm{H}]^{+}, 100 \%\right)$; HRMS $\left(\mathrm{ESI}^{+}\right) \mathrm{C}_{45} \mathrm{H}_{53} \mathrm{~N}_{2} \mathrm{O}_{4}{ }^{+}\left([\mathrm{M}+\mathrm{H}]^{+}\right)$requires 685.4000; found 685.3994.

$(2 R, 3 R, 4 R, \alpha R)-2-B e n z y l o x y-3-[N$-benzyl- $N$-( $\alpha$-methylbenzyl)amino]-4-( $N, N$-dibenzylamino)-5pentanolactone 79 and $(2 S, 3 R, 4 R, \alpha R)-2$-benzyloxy-3-[N-benzyl- $N$-( $\alpha$-methylbenzyl)amino]-4-( $N, N$ dibenzylamino)-5-pentanolactone 80. Method A. NaH (60\% dispersion in mineral oil, $20 \mathrm{mg}, 0.50 \mathrm{mmol}$ ) was added to a stirred solution of 73 (238 mg, $0.457 \mathrm{mmol},>99: 1 \mathrm{dr})$ in THF $(5 \mathrm{~mL})$ at $0{ }^{\circ} \mathrm{C}$ and the resultant solution was stirred at $0{ }^{\circ} \mathrm{C}$ for $30 \mathrm{~min}$. $\mathrm{BnBr}(109 \mu \mathrm{L}, 0.914 \mathrm{mmol})$ was then added and the resultant solution was stirred at rt for $24 \mathrm{~h}$. Satd aq $\mathrm{NH}_{4} \mathrm{Cl}(2 \mathrm{~mL})$ was then added and the organic layer was 
washed sequentially with brine $(10 \mathrm{~mL})$ and $\mathrm{H}_{2} \mathrm{O}(10 \mathrm{~mL})$. The combined aqueous layers were extracted with $\mathrm{Et}_{2} \mathrm{O}(3 \times 15 \mathrm{~mL})$, and the combined organics were dried and concentrated in vacuo. Purification via flash column chromatography (eluent $30-40{ }^{\circ} \mathrm{C}$ petroleum ether/EtOAc, 5:1) gave 73 as a colourless viscous oil (49 mg, 21\%, >99:1 dr). Exhaustive chromatography of the residue gave an 8:92 mixture of $\mathbf{7 9}$ and $\mathbf{8 0}$ as a colourless oil (13 mg, 5\%); $v_{\max } 1753(\mathrm{C}=\mathrm{O}) ; \delta_{\mathrm{H}}\left(400 \mathrm{MHz}\right.$, acetone- $\left.d_{6}\right) 1.08(3 \mathrm{H}, \mathrm{d}, J$ 7.0, C( $\left.\alpha) M e\right), 3.31$ (1H, app q, J 4.3, C(4)H), 3.47 (2H, d, $J$ 13.7, N( $\left.\left.\mathrm{CH}_{\mathrm{A}} \mathrm{H}_{\mathrm{B}} \mathrm{Ph}\right)_{2}\right), 3.54$ (1H, dd, $J$ 8.1, 4.3, C(3)H), 3.66 (2H, d, $J$ 13.7, $\left.\mathrm{N}\left(\mathrm{CH}_{\mathrm{A}} \mathrm{H}_{\mathrm{B}} \mathrm{Ph}\right)_{2}\right), 3.69\left(1 \mathrm{H}, \mathrm{d}, J\right.$ 14.6, $\left.\mathrm{NCH}_{\mathrm{A}} \mathrm{H}_{\mathrm{B}} \mathrm{Ph}\right), 3.80\left(1 \mathrm{H}, \mathrm{d}, J\right.$ 14.6, $\left.\mathrm{NCH}_{\mathrm{A}} H_{\mathrm{B}} \mathrm{Ph}\right), 4.19(1 \mathrm{H}, \mathrm{d}, J$ 10.8, $\left.\mathrm{OCH}_{\mathrm{A}} \mathrm{H}_{\mathrm{B}} \mathrm{Ph}\right), 4.26(1 \mathrm{H}, \mathrm{q}, J$ 7.0, C( $\left.\alpha) H\right), 4.37$ (1H, d, J 8.1, C(2)H), 4.45 (1H, dd, $J$ 12.5, 4.1, C(5)H $\left.H_{\mathrm{A}}\right)$, $4.73\left(1 \mathrm{H}, \mathrm{d}, J\right.$ 10.8, $\left.\mathrm{OCH}_{\mathrm{A}} H_{\mathrm{B}} \mathrm{Ph}\right), 4.73-4.79\left(1 \mathrm{H}, \mathrm{m}, \mathrm{C}(5) H_{\mathrm{B}}\right), 7.00-7.50(25 \mathrm{H}, \mathrm{m}, \mathrm{Ph}) ; \delta_{\mathrm{C}}(125 \mathrm{MHz}$, acetone- $\left.d_{6}\right) 22.6(\mathrm{C}(\alpha) M e), 52.1\left(\mathrm{NCH}_{2} \mathrm{Ph}\right), 55.3\left(\mathrm{~N}\left(\mathrm{CH}_{2} \mathrm{Ph}\right)_{2}\right), 59.5(C(4)), 60.8(C(\alpha)), 62.1(C(3)), 65.0$ (C(5)), $73.1\left(\mathrm{OCH}_{2} \mathrm{Ph}\right), 77.5(C(2)), 127.4,127.9,128.0,128.7,129.1,129.2,129.4,130.1$ (o,m,p-Ph),

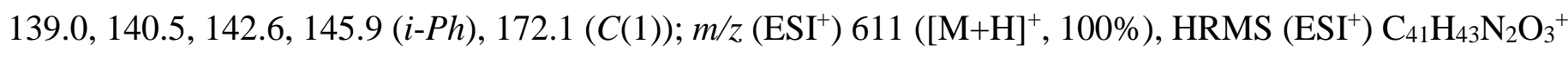
$\left([\mathrm{M}+\mathrm{H}]^{+}\right)$requires 611.3268; found 611.3267.

Method B. $\mathrm{HBF}_{4}(48 \%$ aq, $48 \mu \mathrm{L}, 0.37 \mathrm{mmol})$ was added to a stirred solution of 78 (50 mg, $73 \mu \mathrm{mol}$, >99:1 dr) in $\mathrm{CH}_{2} \mathrm{Cl}_{2}(0.3 \mathrm{~mL})$ at rt and the resultant solution was stirred at rt for $48 \mathrm{~h} . \mathrm{CHCl}_{3} /{ }^{\mathrm{i} O \mathrm{PH}}(3: 1 \mathrm{v} / \mathrm{v}$, $3 \mathrm{~mL}$ ) was then added and the resultant solution was washed with satd aq $\mathrm{NaHCO}_{3}(2 \mathrm{~mL})$, then dried and concentrated in vacuo. Purification via flash column chromatography (eluent $30-40{ }^{\circ} \mathrm{C}$ petroleum ether/EtOAc, 5:1) gave 78 as a colourless oil (15 mg, 30\%, >99:1 dr). Further elution gave a 50:50 mixture of 78 and 79 as a colourless oil (16 mg, 34\% [calculated]). Data for 79: $\delta_{\mathrm{H}}\left(400 \mathrm{MHz}, \mathrm{CDCl}_{3}\right)$ [selected peaks] $1.18(3 \mathrm{H}, \mathrm{d}, J$ 6.9, C( $\alpha) M e)$, 3.39-3.46 (3H, m, C(4)H, N(CHA $\left.\left.\mathrm{H}_{\mathrm{B}} \mathrm{Ph}\right)_{2}\right), 3.58-3.65(1 \mathrm{H}, \mathrm{m}, \mathrm{C}(3) H)$, $\left.3.70\left(2 \mathrm{H}, \mathrm{d}, J \text { 13.9, N( } \mathrm{CH}_{\mathrm{A}} \mathrm{H}_{\mathrm{B}} \mathrm{Ph}\right)_{2}\right), 3.76\left(1 \mathrm{H}, \mathrm{d}, J\right.$ 4.7, C(2)H), 3.90 (2H, app s, $\left.\mathrm{NCH}_{2} \mathrm{Ph}\right), 4.17-4.25$ (2H, m, C(5) $\left.H_{\mathrm{A}}, \mathrm{C}(\alpha) H\right), 4.36\left(1 \mathrm{H}, \mathrm{d}, J\right.$ 11.6, $\left.\mathrm{OCH}_{\mathrm{A}} \mathrm{H}_{\mathrm{B}} \mathrm{Ph}\right), 4.49-4.57\left(1 \mathrm{H}, \mathrm{m}, \mathrm{C}(5) H_{\mathrm{B}}\right), 4.71(1 \mathrm{H}, \mathrm{d}, J 11.6$, $\left.\mathrm{OCH}_{\mathrm{A}} \mathrm{H}_{\mathrm{B}} \mathrm{Ph}\right) ; \delta_{\mathrm{C}}\left(100 \mathrm{MHz}, \mathrm{CDCl}_{3}\right)$ [selected peaks] $20.6(C(\alpha) M e), 52.2\left(\mathrm{NCH}_{2} \mathrm{Ph}\right), 54.6\left(\mathrm{~N}\left(\mathrm{CH}_{2} \mathrm{Ph}\right)_{2}\right)$, $56.9(C(4)), 57.2(C(3)), 59.7(C(\alpha)), 65.5(C(5)), 72.7\left(\mathrm{OCH}_{2} \mathrm{Ph}\right), 77.7(C(2))$.

Method C. TBAF (1.0 M in THF, $0.24 \mathrm{~mL}, 0.24 \mathrm{mmol}$ ) was added to a stirred solution of 77 (100 mg, $0.119 \mathrm{mmol},>99: 1 \mathrm{dr})$ in THF $(2 \mathrm{~mL})$ at $0{ }^{\circ} \mathrm{C}$ and the resultant solution was stirred at rt for $24 \mathrm{~h}$. Et $2 \mathrm{O}$ (2 mL) and $\mathrm{H}_{2} \mathrm{O}(2 \mathrm{~mL})$ were added, and the aqueous layer was extracted with $\mathrm{Et}_{2} \mathrm{O}(3 \times 5 \mathrm{~mL})$. The combined organics were washed with satd aq $\mathrm{NaHCO}_{3}(15 \mathrm{~mL})$, then dried and concentrated in vacuo to give a 39:61 mixture of $\mathbf{7 9}$ and $\mathbf{8 0}$, respectively. Purification via flash column chromatography (eluent 30-40 ${ }^{\circ} \mathrm{C}$ petroleum ether/EtOAc, 5:1) gave a 39:61 mixture of $\mathbf{7 9}$ and $\mathbf{8 0}$ as a colourless oil (38 mg, 52\%).

Method D. TBAF (1.0 M in THF, $0.15 \mathrm{~mL}, 0.15 \mathrm{mmol}$ ) was added to a stirred solution of 78 (50 mg, $0.073 \mathrm{mmol},>99: 1 \mathrm{dr})$ in THF $(1.5 \mathrm{~mL})$ at $0{ }^{\circ} \mathrm{C}$ and the resultant solution was stirred at rt for $24 \mathrm{~h}$. Et $2 \mathrm{O}(1$ 
$\mathrm{mL})$ and $\mathrm{H}_{2} \mathrm{O}(1 \mathrm{~mL})$ were added, and the aqueous layer was extracted with $\mathrm{Et}_{2} \mathrm{O}(3 \times 3 \mathrm{~mL})$. The combined organics were washed with satd aq $\mathrm{NaHCO}_{3}(10 \mathrm{~mL})$, then dried and concentrated in vacuo to give a 50:50 mixture of 79 and 80. Purification via flash column chromatography (eluent 30-40 ${ }^{\circ} \mathrm{C}$ petroleum ether/EtOAc, 5:1) gave a 50:50 mixture of $\mathbf{7 9}$ and $\mathbf{8 0}$ as a colourless oil (23 $\mathbf{m g}, 52 \%)$.

(2R,3R,4R, $\alpha R)$-2-Benzyloxy-3-[ $N$-benzyl- $N$-( $\alpha$-methylbenzyl)amino]-4-( $N, N$-dibenzylamino)-5-

(triisopropylsilyloxy)pentan-1-ol 81. DIBAL-H (1.0 M in PhMe, $11.8 \mathrm{~mL}, 11.8 \mathrm{mmol})$ was added to a stirred solution of 77 (1.66 g, $1.97 \mathrm{mmol}$, >99:1 dr) in PhMe (33 mL) at $-78{ }^{\circ} \mathrm{C}$ and the resultant solution was stirred at rt for $18 \mathrm{~h}$. The resultant solution was cooled to $0{ }^{\circ} \mathrm{C}$ and satd aq $\mathrm{NH}_{4} \mathrm{Cl}(10 \mathrm{~mL})$ and satd aq Rochelle salt (20 mL) were added sequentially. The resultant biphasic mixture was stirred at rt for $18 \mathrm{~h}$, then filtered through Celite ${ }^{\circledR}$ (eluent EtOAc), dried and concentrated in vacuo. Purification via flash column chromatography (eluent $30-40{ }^{\circ} \mathrm{C}$ petroleum ether/EtOAc, 10:1) gave 81 as colourless oil (1.32 g, 87\%, >99:1 dr); $[\alpha]_{\mathrm{D}}^{22}+15.4$ (c 1.0 in $\left.\mathrm{CHCl}_{3}\right) ; v_{\max } 3420(\mathrm{O}-\mathrm{H}) ; \delta_{\mathrm{H}}\left(400 \mathrm{MHz}, \mathrm{CDCl}_{3}\right) 0.95(3 \mathrm{H}, \mathrm{d}, J$ 6.9, $\mathrm{C}(\alpha) M e), 1.04-1.17$ (21H, m, Si(CHMe $\left.)_{3}\right), 1.61$ (1H, br s, OH), 3.24-3.29 (1H, m, C(2)H), 3.33 (1H, dd, $J$ 6.6, 3.5, C(3)H), 3.44-3.61 (5H, m, C(1)H $\left., \mathrm{C}(4) H, \mathrm{C}(\alpha) H, \mathrm{NCH}_{\mathrm{A}} \mathrm{H}_{\mathrm{B}} \mathrm{Ph}\right), 3.72$ (2H, d, J 13.0, $\left.\mathrm{N}\left(\mathrm{CH}_{\mathrm{A}} \mathrm{H}_{\mathrm{B}} \mathrm{Ph}\right)_{2}\right), 3.74\left(1 \mathrm{H}, \mathrm{d}, J\right.$ 14.8, $\left.\mathrm{NCH}_{\mathrm{A}} H_{\mathrm{B}} \mathrm{Ph}\right), 3.98\left(1 \mathrm{H}, \mathrm{dd}, J\right.$ 10.7, 3.8, C(5)H $\left.H_{\mathrm{A}}\right), 4.15(2 \mathrm{H}, \mathrm{d}, J$ 13.0, $\left.\mathrm{N}\left(\mathrm{CH}_{\mathrm{A}} H_{\mathrm{B}} \mathrm{Ph}\right)_{2}\right), 4.20$ (1H, d, $J$ 11.1, $\left.\mathrm{OCH}_{\mathrm{A}} \mathrm{H}_{\mathrm{B}} \mathrm{Ph}\right), 4.41$ (1H, dd, $J$ 10.7, 8.0, C(5)H $\left.H_{\mathrm{B}}\right), 4.60$ (1H, d, $J$ 11.1, $\mathrm{OCH}_{\mathrm{A}} \mathrm{H}_{\mathrm{B}} \mathrm{Ph}$ ), 6.97 (2H, m, Ph), 7.15-7.21 (8H, m, Ph), 7.23-7.30 (7H, m, Ph), 7.35 (4H, t, J 7.4, Ph), 7.44 (4H, d, J 7.0, Ph); $\delta_{\mathrm{C}}\left(100 \mathrm{MHz}, \mathrm{CDCl}_{3}\right) 12.0\left(\mathrm{Si}\left(\mathrm{CHMe}_{2}\right)_{3}\right), 18.2(\mathrm{C}(\alpha) \mathrm{Me}), 18.3\left(\mathrm{Si}(\mathrm{CHMe})_{3}\right), 52.4$ ( $\left.\mathrm{NCH}_{2} \mathrm{Ph}\right), 55.6\left(\mathrm{~N}\left(\mathrm{CH}_{2} \mathrm{Ph}\right)_{2}\right), 57.7(C(\alpha)), 62.0$ (C(5)), 62.3 (C(1)), 63.1 (C(3)), 63.3 (C(4)), 71.1 $\left(\mathrm{OCH}_{2} \mathrm{Ph}\right), 79.5$ (C(2)), 126.5, 126.8, 127.0, 127.5, 127.5, 128.0, 128.1, 128.1, 128.1, 128.3, $128.3,130.0$ (o,m,p-Ph), 137.9, 140.3, 140.4, $143.1(i-P h) ; \quad m / z \quad\left(\mathrm{ESI}^{+}\right) 771\left([\mathrm{M}+\mathrm{H}]^{+}, 100 \%\right) ; \quad \mathrm{HRMS}\left(\mathrm{ESI}^{+}\right)$ $\mathrm{C}_{50} \mathrm{H}_{67} \mathrm{~N}_{2} \mathrm{O}_{3} \mathrm{Si}^{+}\left([\mathrm{M}+\mathrm{H}]^{+}\right)$requires 771.4915; found 771.4907

1-(1'-Phenyl-1H-tetrazol-5'-ylsulfonyl)tridecane 84. Step 1. $\mathrm{K}_{2} \mathrm{CO}_{3}(2.07 \mathrm{~g}, 15.0 \mathrm{mmol})$ and PTSH (1.47 g, $8.23 \mathrm{mmol})$ were added sequentially to a stirred solution of 1-bromotridecane (1.97 $\mathrm{g}, 7.48 \mathrm{mmol})$ in acetone $(30 \mathrm{~mL})$ and the resultant solution was stirred at $65{ }^{\circ} \mathrm{C}$ for $2.5 \mathrm{~h}$. The resultant solution was allowed to cool to rt, then filtered and concentrated in vacuo. The residue was partitioned between $\mathrm{CH}_{2} \mathrm{Cl}_{2}(20 \mathrm{~mL})$ and $\mathrm{H}_{2} \mathrm{O}(20 \mathrm{~mL})$ and the aqueous layer was extracted with $\mathrm{CH}_{2} \mathrm{Cl}_{2}(3 \times 20 \mathrm{~mL})$. The combined organics were washed with $\mathrm{H}_{2} \mathrm{O}(50 \mathrm{~mL})$, then dried and concentrated in vacuo to give 83 as a white solid (2.40 g); $\delta_{\mathrm{H}}$ (400 MHz, CDCl $) 0.89$ (3H, t, J 6.9, C(13)H3), 1.20-1.35 (18H, m, C(4)H2-C(12)H2), 1.40-1.49 (2H, m, C(3) $\left.H_{2}\right), 1.82$ (2H, app quintet, $J$ 7.4, C(2)H $\left.H_{2}\right), 3.40$ (2H, t, $J$ 7.4, C(1) $\left.H_{2}\right), 7.51-7.62(5 \mathrm{H}, \mathrm{m}, P h)$.

Step 2. A solution of the residue 83 (2.40 g) from the previous step in EtOH (100 $\mathrm{mL})$ was added dropwise to a stirred solution of $\left(\mathrm{NH}_{4}\right)_{2} \mathrm{Mo}_{7} \mathrm{O}_{24} \cdot 4 \mathrm{H}_{2} \mathrm{O}(1.85 \mathrm{~g}, 1.50 \mathrm{mmol})$ in $30 \%$ aq $\mathrm{H}_{2} \mathrm{O}_{2}(11.5 \mathrm{~mL}, 112$ 
mmol) at $0{ }^{\circ} \mathrm{C}$ and the resultant solution was stirred at $\mathrm{rt}$ for $18 \mathrm{~h}$. Brine $(100 \mathrm{~mL})$ was added and the aqueous layer was extracted with EtOAc $(3 \times 150 \mathrm{~mL})$. The combined organics were dried and concentrated in vacuo. The residue was suspended in $\mathrm{MeOH}(30 \mathrm{~mL})$ and the resultant suspension was stirred at rt until complete dissolution occurred $(\sim 1 \mathrm{~h})$, then the resultant solution was cooled to $0{ }^{\circ} \mathrm{C}$ and stirred at $0{ }^{\circ} \mathrm{C}$ for 1 h during which time a precipitate formed. The precipitate of $\mathbf{8 4}$ was then collected by filtration, the filtrate was concentrated in vacuo and the above process was repeated twice to give $\mathbf{8 4}$ as a white solid (2.33 g, 79\%); mp 50-52 ${ }^{\circ} \mathrm{C} ; v_{\max } 1339(\mathrm{~S}=\mathrm{O}), 1151(\mathrm{~S}=\mathrm{O}) ; \delta_{\mathrm{H}}\left(400 \mathrm{MHz}, \mathrm{CDCl}_{3}\right) 0.88$ (3H, t, J 6.7, C(13)H3), 1.20-1.28 (18H, m, C(4)H2-C(12) $\left.H_{2}\right), 1.44-1.54$ (2H, m, C(3) $\left.H_{2}\right), 1.89-2.01$ (2H, m, C(2)H $\left.H_{2}\right), 3.68-3.77$ (2H, m, C(1)H $\left.H_{2}\right), 7.55-7.73$ (5H, m, Ph); $\delta_{\mathrm{C}}\left(100 \mathrm{MHz} \mathrm{CDCl}_{3}\right) 14.1$ (C(13)), $21.9(C(2))$, 22.6, 29.1, 29.3, 29.4, 29.5, 29.6 (C(4)-C(12)) 28.1 (C(3)), 56.0 (C(1)), 125.0, 129.7, 131.4 (o,m,p-Ph), 133.0 (i-Ph), 153.4 $\left(C\left(5^{\prime}\right)\right) ; \mathrm{m} / \mathrm{z}\left(\mathrm{ESI}^{+}\right) 415\left([\mathrm{M}+\mathrm{Na}]^{+}, 100 \%\right) ; \mathrm{HRMS}\left(\mathrm{ESI}^{+}\right) \mathrm{C}_{20} \mathrm{H}_{32} \mathrm{O}_{2} \mathrm{~N}_{4} \mathrm{NaS}^{+}\left([\mathrm{M}+\mathrm{Na}]^{+}\right)$requires 415.2138; found 415.2142 .

$(2 R, 3 R, 4 S, \alpha R, E)-1-($ Triisopropylsilyloxy)-2-( $N, N$-dibenzylamino)-3-[ $N$-benzyl- $N-(\alpha-$ methylbenzyl)amino]-4-benzyloxyoctadec-5-ene 85 and $(2 R, 3 R, 4 S, \alpha R, Z)-1$-(triisopropylsilyloxy)-2( $N, N$-dibenzylamino)-3-[ $N$-benzyl- $N$-( $\alpha$-methylbenzyl)amino]-4-benzyloxyoctadec-5-ene 86. Method A. Wittig Olefination. Step 1. IBX (54 mg, $0.19 \mathrm{mmol}$ ) was added to a stirred solution of 81 (50 mg, $65 \mu \mathrm{mol}$, $>99: 1 \mathrm{dr})$ in DMSO $(1 \mathrm{~mL})$ at rt and the resultant solution was stirred at $\mathrm{rt}$ for $18 \mathrm{~h}$. $\mathrm{Et}_{2} \mathrm{O}(2 \mathrm{~mL})$ was added and the resultant solution was washed with $\mathrm{H}_{2} \mathrm{O}(5 \times 2 \mathrm{~mL})$, then dried and concentrated in vacuo to give 82 as a yellow oil (41 mg).

Step 2. BuLi (2.2 M in hexanes, $88 \mu \mathrm{L}, 0.19 \mathrm{mmol}$ ) was added dropwise to a stirred solution of $\left[\mathrm{C}_{13} \mathrm{H}_{27} \mathrm{PPh}_{3}\right]^{+}[\mathrm{Br}]^{-}(0.10 \mathrm{~g}, 0.19 \mathrm{mmol})$ in THF $(1.2 \mathrm{~mL})$ at $0{ }^{\circ} \mathrm{C}$ and the resultant solution was stirred at 0 ${ }^{\circ} \mathrm{C}$ for $30 \mathrm{~min}$. A solution of the residue $82(41 \mathrm{mg})$ from the previous step in THF $(1.2 \mathrm{~mL})$ at $0{ }^{\circ} \mathrm{C}$ was then added dropwise via cannula and the resultant solution was stirred at $75^{\circ} \mathrm{C}$ for $2 \mathrm{~h}$. The resultant solution was allowed to cool to rt, then $\mathrm{H}_{2} \mathrm{O}(1 \mathrm{~mL})$ and brine $(1 \mathrm{~mL})$ were added sequentially and the aqueous layer was extracted with EtOAc $(3 \times 5 \mathrm{~mL})$. The combined organics were washed with satd aq $\mathrm{NaHCO}_{3}(10 \mathrm{~mL})$ then dried and concentrated in vacuo. Purification via flash column chromatography (eluent $30-40{ }^{\circ} \mathrm{C}$ petroleum ether/ $\mathrm{Et}_{2} \mathrm{O}, 50: 1$ ) gave an impure sample of $\mathbf{8 6}$ as a colourless oil (24 mg, $90 \%$ purity, $35 \%$, $>95: 5 \mathrm{dr}$ [(E):(Z) ratio]); $v_{\max } 1602(\mathrm{C}=\mathrm{C}) ; \delta_{\mathrm{H}}\left(500 \mathrm{MHz}, \mathrm{CDCl}_{3}\right) 0.87$ (3H, t, J 6.9, C(18)H3), 1.01-1.12 (24H, m, $\left.\mathrm{C}(\alpha) M e, \mathrm{Si}(\mathrm{CHMe})_{3}\right), 1.22-1.31\left(20 \mathrm{H}, \mathrm{m}, \mathrm{C}(8) \mathrm{H}_{2}-\mathrm{C}(17) \mathrm{H}_{2}\right), 1.84-1.93$ (1H, m, C(7) $\left.\mathrm{H}_{\mathrm{A}}\right), 1.97-2.06(1 \mathrm{H}$, m, C(7)H $\left.H_{\mathrm{B}}\right), 3.20$ (1H, dd, J 6.9, 3.8, C(3)H), 3.54 (2H, d, J 13.9, ( $\left.\left(\mathrm{N}_{(\mathrm{C}} \mathrm{CH}_{\mathrm{B}} \mathrm{Ph}\right)_{2}\right), 3.49-3.56(1 \mathrm{H}, \mathrm{m} \mathrm{C}(2) H)$, 3.69 (1H, d, $J$ 15.3, $\left.\mathrm{NCH}_{\mathrm{A}} \mathrm{H}_{\mathrm{B}} \mathrm{Ph}\right), 3.79$ (1H, d, $J$ 11.2, $\left.\mathrm{OCH}_{\mathrm{A}} \mathrm{H}_{\mathrm{B}} \mathrm{Ph}\right), 3.92(1 \mathrm{H}, \mathrm{q}, J$ 6.8, C $(\alpha) H), 3.93-4.00$ (3H, m, N(CH $\left.\left.\mathrm{CH}_{\mathrm{B}} \mathrm{Ph}\right)_{2}, \mathrm{NCH}_{\mathrm{A}} H_{\mathrm{B}} \mathrm{Ph}\right), 4.16\left(1 \mathrm{H}, \mathrm{dd}, J\right.$ 10.6, 6.0, C(1)H $\left.H_{\mathrm{A}}\right), 4.21\left(1 \mathrm{H}, \mathrm{dd}, J 10.6,5.8, \mathrm{C}(1) H_{\mathrm{B}}\right)$, 
4.31-4.38 (2H, m, C(4)H, $\left.\mathrm{OCH}_{\mathrm{A}} H_{\mathrm{B}} \mathrm{Ph}\right), 5.23$ (1H, app t, J 10.6, C(5)H), 5.49-5.56 (1H, m, C(6)H), 7.007.28 (25H, m, Ph); $\delta_{\mathrm{C}}\left(125 \mathrm{MHz}, \mathrm{CDCl}_{3}\right) 12.0\left(\mathrm{Si}\left(\mathrm{CHMe}_{2}\right)_{3}\right), 14.1$ (C(18)), 18.2 (Si(CHMe $\left.)_{3}\right), 20.3$ (C( $(\alpha) M e), 22.7$ (C(17)), 29.4, 29.5, 29.6, 29.6, 29.7, 31.9 (C(8)-C(16)), 27.9 (C(7)), $51.8\left(\mathrm{NCH}_{2} \mathrm{Ph}\right), 55.1$ $\left(\mathrm{N}\left(\mathrm{CH}_{2} \mathrm{Ph}\right)_{2}\right), 58.3(C(\alpha)), 61.1(C(1)), 62.9(C(2)), 64.6(C(3)), 69.2\left(\mathrm{OCH}_{2} \mathrm{Ph}\right), 74.7(C(4)), 125.9,126.3$, 126.5, 126.9, 127.2, 127.7, 127.7, 127.9, 128.0, 128.0, 128.4, 128.4 (o,m,p-Ph), 129.4 (C(5)), 133.6 (C(6)), 138.8, 141.0, 142.1, 145.3 (i-Ph); m/z (ESI $\left.{ }^{+}\right) 937$ (100\%), $936\left([\mathrm{M}+\mathrm{H}]^{+}, 56 \%\right), 833$ (70\%); HRMS (ESI $)$ $\mathrm{C}_{63} \mathrm{H}_{91} \mathrm{~N}_{2} \mathrm{O}_{2} \mathrm{Si}^{+}\left([\mathrm{M}+\mathrm{H}]^{+}\right)$requires 935.6844; found 935.6833.

Method B. Julia Olefination. Step 1. IBX (406 mg, $1.45 \mathrm{mmol}$ ) was added to a stirred solution of 81 (372 mg, $0.482 \mathrm{mmol})$ in DMSO $(7.5 \mathrm{~mL})$ at rt and the resultant solution was stirred at rt for $18 \mathrm{~h}$. $\mathrm{Et}_{2} \mathrm{O}(20$ $\mathrm{mL}$ ) was added and the resultant solution was washed with $\mathrm{H}_{2} \mathrm{O}(5 \times 30 \mathrm{~mL})$, then dried and concentrated in vacuo to give 82 as a yellow oil (325 mg).

Step 2. LiHMDS (1.0 M in THF, $0.88 \mathrm{~mL}, 0.88 \mathrm{mmol}$ ) was added dropwise via syringe to a stirred solution of the residue 82 (325 mg) from the previous step and 84 (172 mg, $0.439 \mathrm{mmol}$ ) in THF (1.5 mL) at $-10{ }^{\circ} \mathrm{C}$, and the resultant solution was stirred at $\mathrm{rt}$ for $18 \mathrm{~h}$. The resultant solution was cooled to $0{ }^{\circ} \mathrm{C}$ and then satd aq $\mathrm{NH}_{4} \mathrm{Cl}(1 \mathrm{~mL})$ and brine $(3 \mathrm{~mL})$ were added sequentially. The aqueous layer was extracted with $\mathrm{Et}_{2} \mathrm{O}(3 \times 5 \mathrm{~mL})$ and the combined organics were dried and concentrated in vacuo to give an 82:18 mixture of 85 and 86, respectively. Purification via flash column chromatography (eluent $30-40{ }^{\circ} \mathrm{C}$ petroleum ether/Et ${ }_{2} \mathrm{O}, 40: 1$ ) gave an 82:18 mixture of $\mathbf{8 5}$ and $\mathbf{8 6}$ as a pale yellow oil (312 $\left.\mathrm{mg}, 69 \%\right)$. Data for mixture: $v_{\max } 1603(\mathrm{C}=\mathrm{C}) ; \mathrm{m} / \mathrm{z}\left(\mathrm{ESI}^{+}\right) 937$ (100\%), $936\left([\mathrm{M}+\mathrm{H}]^{+}, 67 \%\right), 833$ (50\%); HRMS $\left(\mathrm{ESI}^{+}\right) \mathrm{C}_{63} \mathrm{H}_{91} \mathrm{~N}_{2} \mathrm{O}_{2} \mathrm{Si}^{+}$ $\left([\mathrm{M}+\mathrm{H}]^{+}\right)$requires 935.6844; found 935.6816. Data for 85: $\delta_{\mathrm{H}}\left(400 \mathrm{MHz}, \mathrm{CDCl}_{3}\right)$ 0.87-0.93 $(3 \mathrm{H}, \mathrm{m}$, $\left.\mathrm{C}(18) \mathrm{H}_{3}\right), 1.05-1.17$ (24H, m, C( $\left.\alpha\right) \mathrm{Me}$, Si $\left.(\mathrm{CHMe})_{3}\right), 1.27-1.38\left(20 \mathrm{H}, \mathrm{m}, \mathrm{C}(8) \mathrm{H}_{2}-\mathrm{C}(17) \mathrm{H}_{2}\right), 1.83-2.07$ (4H, m, C(7)H $\left.H_{2}\right)$ 3.17-3.26 (1H, m, C(3)H), 3.49-3.60 (3H, m, C(2)H, N(CHA $\left.\left.\mathrm{CH}_{\mathrm{B}} \mathrm{Ph}\right)_{2}\right), 3.63-3.76(1 \mathrm{H}, \mathrm{m}$, $\mathrm{NCH}_{\mathrm{A}} \mathrm{H}_{\mathrm{B}} \mathrm{Ph}$ ), 3.78-3.84 (1H, m, OCH $\left.\mathrm{AH}_{\mathrm{B}} \mathrm{Ph}\right), 3.91-3.99\left(2 \mathrm{H}, \mathrm{m}, \mathrm{C}(\alpha) H, \mathrm{NCH}_{\mathrm{A}} H_{\mathrm{B}} \mathrm{Ph}\right), 3.99-4.04(2 \mathrm{H}, \mathrm{m}$, $\left.\mathrm{N}\left(\mathrm{CH}_{\mathrm{A}} H_{\mathrm{B}} \mathrm{Ph}\right)_{2}\right), 4.19\left(1 \mathrm{H}, \mathrm{dd}, J 10.4,5.8, \mathrm{C}(1) H_{\mathrm{A}}\right), 4.25\left(1 \mathrm{H}, \mathrm{dd}, J 10.4,5.8, \mathrm{C}(1) H_{\mathrm{B}}\right), 4.30-4.42$ (2H, m, $\left.\mathrm{C}(4) H, \mathrm{OCH}_{\mathrm{A}} H_{\mathrm{B}} \mathrm{Ph}\right), 5.15-5.32$ (1H, m, C(5)H), 5.52-5.60 (1H, m, C(6)H), 7.08-7.40 (25H, m, Ph); $\delta_{\mathrm{C}}(100$ $\left.\mathrm{MHz}, \mathrm{CDCl}_{3}\right) 12.0\left(\mathrm{Si}\left(\mathrm{CHMe}_{2}\right)_{3}\right), 14.2$ (C(18)), 18.3 (Si(CHMe$\left.)_{3}\right), 19.1(\mathrm{C}(\alpha) M e), 22.7(C(17)), 29.3,29.4$, 29.5, 29.6, 29.6, 29.8, 30.3, 30.9, 32.0 (C(8)-C(16)), 32.3 (C(7)), $51.8\left(\mathrm{NCH}_{2} \mathrm{Ph}\right), 55.3\left(\mathrm{~N}\left(\mathrm{CH}_{2} \mathrm{Ph}\right)_{2}\right), 57.4$ (C( $(\alpha)), 61.7(C(1)), 63.5(C(2)), 64.2(C(3)), 69.5\left(\mathrm{OCH}_{2} \mathrm{Ph}\right), 81.6(C(4)), 126.1,126.3,126.4,127.0,127.4$, 127.7, 127.8, 127.9, 128.0, 128.2, 128.3 (o,m,p-Ph), 130.3 (C(5)), 134.2 (C(6)), 138.9, 141.2, 141.7, 144.4 $(i-P h)$;

$(2 R, 3 R, 4 S, \alpha R, E)-2-(N, N$-Dibenzylamino)-3-[ $N$-benzyl- $N$-( $\alpha$-methylbenzyl)amino]-4- 
methylbenzyl)amino]-4-(benzyloxy)octadec-5-en-1-ol 88. Method A. TBAF (1.0 M in THF, $0.42 \mathrm{~mL}, 0.42$ mmol) was added to a stirred solution of an 82:18 mixture of 85 and $\mathbf{8 6}$ (195 mg, 0.207 mmol) in THF (4 $\mathrm{mL})$ at $0{ }^{\circ} \mathrm{C}$ and the resultant solution was stirred at $\mathrm{rt}$ for $18 \mathrm{~h}$. $\mathrm{Et}_{2} \mathrm{O}(2 \mathrm{~mL})$ and $\mathrm{H}_{2} \mathrm{O}(2 \mathrm{~mL})$ were added and the aqueous layer was extracted with $\mathrm{Et}_{2} \mathrm{O}(3 \times 5 \mathrm{~mL})$. The combined organics were washed with satd aq $\mathrm{NaHCO}_{3}(15 \mathrm{~mL})$, then dried and concentrated in vacuo. Purification via flash column chromatography (eluent $30-40{ }^{\circ} \mathrm{C}$ petroleum ether/Et $2 \mathrm{O}, 30: 1$; increased to $30-40{ }^{\circ} \mathrm{C}$ petroleum ether/Et $2 \mathrm{O}, 5: 1$ ) gave an 82:18 mixture of $\mathbf{8 5}$ and $\mathbf{8 6}$ as a pale yellow oil ( $40 \mathrm{mg}, 21 \%$ ). Further elution gave an 82:18 mixture of $\mathbf{8 7}$ and 88 as a colourless oil (111 mg, 68\%). Data for mixture: $v_{\max } 3453(\mathrm{O}-\mathrm{H}), 1602(\mathrm{C}=\mathrm{C})$; m/z $\left(\mathrm{ESI}^{+}\right) 780$ ([M+1+H] $\left.]^{+}, 100 \%\right), 779\left([\mathrm{M}+\mathrm{H}]^{+}, 98 \%\right)$; HRMS $\left(\mathrm{ESI}^{+}\right) \mathrm{C}_{54} \mathrm{H}_{71} \mathrm{~N}_{2} \mathrm{O}_{2}{ }^{+}\left([\mathrm{M}+\mathrm{H}]^{+}\right)$requires 779.5510; found 779.5498. Data for 87: $\delta_{\mathrm{H}}\left(500 \mathrm{MHz}, \mathrm{CDCl}_{3}\right) 0.89\left(3 \mathrm{H}, \mathrm{t}, J\right.$ 6.9, C(18)H3), 1.24-1.30 (20H, m, C(8) $H_{2}-$ C(17) $\left.H_{2}\right), 1.33$ (3H, d, J 7.0, C( $\left.\left.\alpha\right) M e\right), 1.91-2.06$ (2H, m, C(7)H $), 3.26$ (1H, dd, $J$ 6.2, 3.4, C(3)H), 3.41 (1H, app q, $J$ 6.0, C(2)H), $\left.3.57\left(2 \mathrm{H}, \mathrm{d}, J \text { 14.0, N(CH} \mathrm{CH}_{\mathrm{B}} \mathrm{Ph}\right)_{2}\right), 3.64-3.83\left(7 \mathrm{H}, \mathrm{m}, \mathrm{C}(1) H_{2}, \mathrm{C}(4) H\right.$, $\left.\mathrm{N}\left(\mathrm{CH}_{\mathrm{A}} H_{\mathrm{B}} \mathrm{Ph}\right)_{2}, \mathrm{NCH}_{\mathrm{A}} \mathrm{H}_{\mathrm{B}} \mathrm{Ph}, \mathrm{OCH}_{\mathrm{A}} \mathrm{H}_{\mathrm{B}} \mathrm{Ph}\right), 3.96(1 \mathrm{H}, \mathrm{q}, J$ 7.0, $\mathrm{C}(\alpha) H), 4.25\left(1 \mathrm{H}, \mathrm{d}, J\right.$ 15.4, $\left.\mathrm{NCH}_{\mathrm{A}} H_{\mathrm{B}} \mathrm{Ph}\right), 4.33$ (1H, d, $J$ 11.2, $\left.\mathrm{OCH}_{\mathrm{A}} H_{\mathrm{B}} \mathrm{Ph}\right), 5.30$ (1H, dd, $J$ 15.7, 7.7, C(5)H), 5.36-5.44 (1H, m, C(6)H), 7.11-7.36 (25H, m, Ph); $\delta_{\mathrm{C}}\left(125 \mathrm{MHz}, \mathrm{CDCl}_{3}\right) 14.2(C(18)), 21.7(\mathrm{C}(\alpha) M e), 22.7(C(17)), 29.2,29.3,29.4,29.5$, 29.6, 29.7, 30.3, 31.9 (C(8)-C(16)), $32.4(C(7)), 52.0\left(\mathrm{NCH}_{2} \mathrm{Ph}\right), 54.5\left(\mathrm{~N}\left(\mathrm{CH}_{2} \mathrm{Ph}\right)_{2}\right), 58.1(C(\alpha)), 60.0(C(1)), 62.8$ (C(3)), $62.9(C(2)), 69.8\left(\mathrm{OCH}_{2} \mathrm{Ph}\right), 80.3(C(4)), 125.5,126.5,126.8,127.5,127.7,128.0,128.2,128.3$, 128.3, 128.5, 129.2 (o,m,p-Ph), $129.8(C(5)), 134.5(C(6)), 138.0,140.3,141.4,144.4(i-P h)$. Data for 88: $\delta_{H}$ (500 MHz, $\mathrm{CDCl}_{3}$ ) [selected peaks] 0.86-0.93 (3H, m, C(18) $\left.H_{3}\right), 1.24-1.30\left(20 \mathrm{H}, \mathrm{m}, \mathrm{C}(8) H_{2}-\mathrm{C}(17) \mathrm{H}_{2}\right)$, 1.98-2.06 (1H, m, C(7)H $\left.H_{\mathrm{A}}\right), 1.96-1.98$ (1H, m, C(7)Hв), 3.16 (1H, dd, J 6.2, 3.2, C(3)H), 3.39-3.50 (3H, m, $\left.\mathrm{C}(2) H, \mathrm{~N}\left(\mathrm{CH}_{\mathrm{A}} \mathrm{H}_{\mathrm{B}} \mathrm{Ph}\right)_{2}\right), 3.55-3.61\left(1 \mathrm{H}, \mathrm{m}, \mathrm{OCH}_{\mathrm{A}} \mathrm{H}_{\mathrm{B}} \mathrm{Ph}\right), 3.65-3.85\left(2 \mathrm{H}, \mathrm{m}, \mathrm{N}\left(\mathrm{CH}_{\mathrm{A}} H_{\mathrm{B}} \mathrm{Ph}\right)_{2}\right), 4.02(1 \mathrm{H}, \mathrm{q}, J$ 7.2, C( $\alpha) H), 4.30$ (1H, d, $J$ 11.2, $\left.\mathrm{OCH}_{\mathrm{A}} H_{\mathrm{B}} \mathrm{Ph}\right), 4.40$ (1H, dd, $J$ 10.0, 3.0, C(4)H), 5.35-5.45 (1H, m, C(5)H), 5.53-5.63 (1H, m, C(6)H); $\delta_{\mathrm{C}}\left(125 \mathrm{MHz}, \mathrm{CDCl}_{3}\right)$ [selected peaks] $14.2(C(18)), 22.7(C(17)), 27.9(C(7))$, $54.2\left(\mathrm{~N}\left(\mathrm{CH}_{2} \mathrm{Ph}\right)_{2}\right), 58.5(C(\alpha)), 62.2(C(2)), 63.7(C(3)), 69.6\left(\mathrm{OCH}_{2} \mathrm{Ph}\right), 75.5(C(4)), 129.5(C(5)), 134.2$ $(C(6))$.

Method B. HF (70\% in pyridine, $172 \mu \mathrm{L}, 6.64 \mathrm{mmol}$ ) was added to a stirred solution of an 82:18 mixture of 85 and 86 (207 mg, $0.221 \mathrm{mmol}$ ) in THF (4 mL) at $0{ }^{\circ} \mathrm{C}$ and the resultant mixture was stirred at rt for $18 \mathrm{~h}$. Satd aq $\mathrm{NaHCO}_{3}(10 \mathrm{~mL})$ was added and the aqueous layer was extracted with EtOAc $(3 \times 15 \mathrm{~mL})$, then the combined organics were dried and concentrated in vacuo. Purification via flash column chromatography (eluent $30-40{ }^{\circ} \mathrm{C}$ petroleum ether/EtOAc/35\% aq $\mathrm{NH}_{4} \mathrm{OH}, 90: 10: 1$ ) gave an 82:18 mixture of 87 and 88 as a colourless oil (149 mg, 86\%). 
(2R,3R,4S)-2,3-Diacetamidooctadecan-1,4-diyl diacetate 89. Step 1. $\mathrm{Pd}(\mathrm{OH})_{2} / \mathrm{C}(50 \% \mathrm{w} / \mathrm{w}$ of substrate, $122 \mathrm{mg}$ ) was added to a vigorously stirred solution of an 82:18 mixture of 87 and 88 (243 mg, $0.312 \mathrm{mmol})$ in degassed $\mathrm{HCl}(1.25 \mathrm{M}$ in $\mathrm{MeOH}, 3 \mathrm{~mL})$ at $\mathrm{rt}$ and the resultant suspension was stirred under $\mathrm{H}_{2}$ (5 atm) at rt for $72 \mathrm{~h}$, then filtered through Celite ${ }^{\circledR}$ (eluent $\mathrm{MeOH}$ ) and concentrated in vacuo.

Step 2. $\mathrm{Ac}_{2} \mathrm{O}(590 \mu \mathrm{L}, 6.24 \mathrm{mmol})$ and DMAP (3.8 $\left.\mathrm{mg}, 0.031 \mathrm{mmol}\right)$ were added sequentially to a stirred solution of the residue from the previous step in pyridine ( $879 \mu \mathrm{L}, 10.9 \mathrm{mmol}$ ) at rt, and the resultant solution was stirred at rt for $72 \mathrm{~h}$. EtOAc $(5 \mathrm{~mL})$ was added, the resultant solution was washed with satd aq $\mathrm{CuSO}_{4}(10 \mathrm{~mL})$, and the aqueous layer was extracted with EtOAc $(3 \times 20 \mathrm{~mL})$. The combined organics were washed with satd aq $\mathrm{NaHCO}_{3}(3 \times 50 \mathrm{~mL})$ and the combined aqueous layers were then extracted with EtOAc $(3 \times 50 \mathrm{~mL})$. The combined organics were dried and concentrated in vacuo. Purification via flash column chromatography (eluent $\mathrm{PhMe} / \mathrm{PrOH}, 4: 1$ ) gave 89 as pale orange solid (109 mg, 72\%, >99:1 dr); mp 73-75 ${ }^{\circ} \mathrm{C} ;[\alpha]_{\mathrm{D}}^{22}-28.9\left(\right.$ c 1.0 in $\left.\mathrm{CHCl}_{3}\right) ; v_{\max } 3292(\mathrm{~N}-\mathrm{H}), 1740(\mathrm{C}=\mathrm{O}$, ester $), 1657\left(\mathrm{C}=\mathrm{O}\right.$, amide); $\delta_{\mathrm{H}}$ (400 MHz, $\left.\mathrm{CDCl}_{3}\right) 0.87$ (3H, t, J 6.8, C(18)H3), 1.18-1.33 (24H, m, C(6)H $\left.\mathrm{H}_{2}-\mathrm{C}(17) \mathrm{H}_{2}\right), 1.53-1.61$ (2H, m, C(5)H2), 1.95 (3H, s, COMe), 1.99 (3H, s, COMe), 2.05 (3H, s, COMe), 2.09 (3H, s, COMe), 4.08-4.27 (4H, m, C(1)H $\left.H_{2}, \mathrm{C}(2) H, \mathrm{C}(3) H\right), 4.91$ (1H, app q, $J$ 5.9, C(4)H), 6.47-6.62 (2H, m, NH); $\delta_{\mathrm{C}}\left(100 \mathrm{MHz}, \mathrm{CDCl}_{3}\right)$ 14.1 (C(18)), 20.8, 21.0 (COMe), 22.6 (C(17)), 23.2, 23.2 (COMe), 25.4, 29.3, 29.4, 29.5, 29.5, 29.6, 29.6, 29.6, 29.6, 30.2, 31.9 (C(5)-C(16)), 49.2 (C(2)), 52.4 (C(3)), $63.4(C(1)), 72.6(C(4)), 171.0(C O M e) ; ~ m / z$

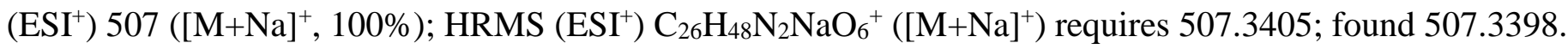

Supporting Information Available: Copies of ${ }^{1} \mathrm{H}$ and ${ }^{13} \mathrm{C}$ NMR spectra, and crystallographic information file (for structures CCDC 1533117 and CCDC 1533118). This material is available free of charge via the Internet at http://pubs.acs.org.

${ }^{\dagger}$ Deceased (26 $6^{\text {th }}$ July 2015).

\section{References and Notes}

${ }^{1}$ For reviews of syntheses of sphingoid bases, see: (a) Koskinen, P. M.; Koskinen, A. M. P. Synthesis 1998, 1075. (b) Howell, A. R.; Ndakala, A. J. Curr. Org. Chem. 2002, 6, 365. (c) Howell, A. R.; So, R. C.; Richardson, S. K. Tetrahedron 2004, 60, 11327. (d) Gao, Y.; He, X.; Ding, F.; Zhang, Y. Synthesis 2016, 48, 4017. For selected examples of syntheses of sphingoid bases, see: (e) Abraham, E.; Davies, S. G.; Millican, N. L.; Nicholson, R. L.; Roberts, P. M.; Smith, A. D. Org. Biomol. Chem. 2008, 6, 1655. (f) Cai, Y.; Ling. C.-C.; Bundle, D. R. Carbohydr. Res. 2009, 344, 2120. (g) Ait-Youcef, R.; Moreau, X.; Greck, C. J. Org. 
Chem. 2010, 75, 5312. (h) Kumar, P.; Dubey, A.; Puranik. V. G. Org. Biomol. Chem. 2010, 8, 5074. (i) Calder, E. D. D.; Zaed, A. M.; Sutherland, A. J. Org. Chem. 2013, 78, 7223. (j) Siciliano, C.; Barattucci, A.; Bonaccorsi, P.; Di Gioia, M. L.; Leggio, A.; Minuti, L.; Romio, E.; Temperini, A. J. Org. Chem. 2014, 79, 5320. (k) Silveira-Dorta, G.; Donadel, O. J.; Martín, V. S.; Padrón, J. M. J. Org. Chem. 2014, 79, 6775.

${ }^{2}$ For selected examples, see: (a) Kolter, T.; van Echten-Deckert, G.; Sandhoff, K. Tetrahedron 1994, 50, 13425. (b) Teare, H.; Huguet, F.; Tredwell, M.; Thibaudeau, S.; Luthra, S.; Gouverneur, V. ARKIVOC 2007 (x), 232. (c) Qu, W.; Ploessl, K.; Truong, H; Kung. M.-P.; Kung, H. F. Bioorg. Med. Chem. Lett. 2009, 19, 3382. (d) Mathew, T.; Billaud, C.; Billich, A.; Cavallari, M.; Nussbaumer, P.; De Libero, G.; Vasella, A. Chem. Biodivers. 2009, 6, 725. (e) Cresswell, A. J.; Davies, S. G.; Lee, J. A.; Morris, M. J.; Roberts, P. M.; Thomson, J. E. J. Org. Chem. 2011, 76, 4617. (f) Cresswell, A. J.; Davies, S. G.; Lee, J. A.; Morris, M. J.; Roberts, P. M.; Thomson, J. E. J. Org. Chem. 2012, 77, 7262. (g) Sridhara, P. R.; Suresha, M.; Kumara, P. V.; Seshadria, K.; Rao, C. V. Carbohydr. Res. 2012, 360, 40. (h) Dai, Z.; Green, T. K. J. Org. Chem. 2014, 79, 7778.

${ }^{3}$ Davies, S. G.; Lee, J. A.; Roberts, P. M.; Thompson, J. E.; Yin, J. Org. Lett. 2012, 14, 218.

${ }^{4}$ For a review, see: Davies, S. G.; Fletcher, A. M.; Roberts, P. M.; Thomson, J. E. Tetrahedron: Asymmetry 2012, 23, 1111.

${ }^{5}$ Masamune, S.; Choy, W.; Petersen, J. S.; Sita, L. R. Angew. Chem. Int. Ed. Engl. 1985, $24,1$.

${ }^{6}$ Bunnage, M. E.; Davies, S. G.; Goodwin, C. J. Synlett 1993, 731.

${ }^{7}$ Bunnage, M. E.; Davies, S. G.; Goodwin, C. J.; Ichihara, O. Tetrahedron 1994, 50, 3975.

${ }^{8}$ Bunnage, M. E.; Burke, A. J.; Davies, S. G.; Goodwin, C. J. Tetrahedron: Asymmetry 1994, 5, 203.

${ }^{9}$ Bunnage, M. E.; Burke, A. J.; Davies, S. G.; Goodwin, C. J. Tetrahedron: Asymmetry 1995, 6, 165.

${ }^{10}$ Hulme, A. N.; Montgomery, C. H.; Henderson, D. K. J. Chem. Soc., Perkin Trans. 1 2000, 1837.

11 The enantiomeric purity of $(R)-\mathbf{4 3}$ was determined by chiral HPLC analysis for which the authors would like to thank Dr. Pavol Jakubec and Prof. Darren J. Dixon.

${ }^{12}$ As used in ref 3, for example.

${ }^{13}$ Horeau, A. Tetrahedron 1975, 31, 1307.

${ }^{14}$ For 16: $2.50\left(1 \mathrm{H}, \mathrm{dd}, J\right.$ 16.0, 5.0, C(2)H $\left.H_{\mathrm{A}}\right), 2.64(1 \mathrm{H}, \mathrm{dd}, J$ 16.0, 6.9, C(2)HB $)$. For 44: $2.51(1 \mathrm{H}, \mathrm{dd}, J$ 15.8, 4.7, C(2)H $\left.H_{\mathrm{A}}\right), 2.71\left(1 \mathrm{H}, \mathrm{dd}, J 15.8,6.9, \mathrm{C}(2) H_{\mathrm{B}}\right)$. For 21: $2.21\left(1 \mathrm{H}, \mathrm{dd}, J 17.0,6.6, \mathrm{C}(2) H_{\mathrm{A}}\right), 3.18(1 \mathrm{H}$, dd, $J$ 17.0, 3.2, C(2)HB $)$. For 45: 2.09 (1H, dd, $J$ 16.7, 6.3, C(2)H $\left.H_{\mathrm{A}}\right), 3.10\left(1 \mathrm{H}, \mathrm{dd}, J 16.7,3.2, \mathrm{C}(2) H_{\mathrm{B}}\right)$.

15 Crystallographic data (excluding structure factors) have been deposited with the Cambridge Crystallographic Data Centre as supplementary publication numbers CCDC 1533117 (52) and CCDC 1533118 (60). 
${ }^{16}$ Flack, H. D. Acta Crystallogr., Sect. A 1983, 39, 876.

${ }^{17}$ Flack, H. D.; Bernardinelli, G. J. Appl. Crystallogr. 2000, 33, 1143.

${ }^{18}$ For a related example of this phenomenon, see: Davies, S. G.; Foster, E. M.; Lee, J. A.; Roberts, P. M.; Thomson, J. E. J. Org. Chem. 2014, 79, 9686.

${ }^{19}$ The concentrations of the solutions employed were $0.21 \mathrm{M}$ in PhMe w.r.t. 55 (neglecting the volume of DIBAL-H solution added) and $0.62 \mathrm{M}$ in THF w.r.t. $\left[\mathrm{C}_{13} \mathrm{H}_{27} \mathrm{PPh}_{3}\right]^{+}[\mathrm{Br}]^{-}$.

${ }^{20}$ Jacobsen, N. E. NMR Data Interpretation Explained: Understanding $1 D$ and $2 D$ NMR Spectra of Organic Compounds and Natural Products, John Wiley \& Sons, Inc. 2016.

${ }^{21}$ Peak overlap in the ${ }^{1} \mathrm{H}$ NMR spectrum of the crude reaction mixture precluded the assessment of a product ratio.

${ }^{22}$ Blakemore, P. R.; Cole, W. J.; Kocieński, P. J.; Morley A. Synlett 1998, 26.

${ }^{23}$ Pangborn, A. B.; Giardello, M. A.; Grubbs, R. H.; Rosen, R. K.; Timmers, F. J. Organometallics 1996, 15, 1518.

${ }^{24}$ Betteridge, P. W.; Carruthers, J. R.; Cooper, R. I.; Prout, C. K.; Watkin, D. J. J. Appl. Crystallogr. 2003, 36, 1487.

${ }^{25}$ Nicholas, G. M.; Molinski, T. F. J. Am. Chem. Soc. 2000, 122, 4011. 